\title{
Return to Zion : gender identity and religion in a proscriptive subculture
}

Citation for published version (APA):

Sohier, R. (1983). Return to Zion : gender identity and religion in a proscriptive subculture. [Doctoral Thesis, Maastricht University]. Rijksuniversiteit Limburg. https://doi.org/10.26481/dis.19831110rs

Document status and date:

Published: 01/01/1983

DOI:

10.26481/dis.19831110rs

Document Version:

Publisher's PDF, also known as Version of record

\section{Please check the document version of this publication:}

- A submitted manuscript is the version of the article upon submission and before peer-review. There can be important differences between the submitted version and the official published version of record.

People interested in the research are advised to contact the author for the final version of the publication, or visit the DOI to the publisher's website.

- The final author version and the galley proof are versions of the publication after peer review.

- The final published version features the final layout of the paper including the volume, issue and page numbers.

Link to publication

\footnotetext{
General rights rights.

- You may freely distribute the URL identifying the publication in the public portal. please follow below link for the End User Agreement:

www.umlib.nl/taverne-license

Take down policy

If you believe that this document breaches copyright please contact us at:

repository@maastrichtuniversity.nl

providing details and we will investigate your claim.
}

Copyright and moral rights for the publications made accessible in the public portal are retained by the authors and/or other copyright owners and it is a condition of accessing publications that users recognise and abide by the legal requirements associated with these

- Users may download and print one copy of any publication from the public portal for the purpose of private study or research.

- You may not further distribute the material or use it for any profit-making activity or commercial gain

If the publication is distributed under the terms of Article $25 \mathrm{fa}$ of the Dutch Copyright Act, indicated by the "Taverne" license above, 
RETURN TO ZION: GENDER IDENTITY

AND RELIGION IN A PROSCRIPTIVE SUBCULTURE

\section{PROEFSCHRIFT}

ter verkrijging van de graad van doctor in de Sociale Wetenschappen aan de Rijksuniversiteit Limburg te Maastricht op gezag van de Rector Magnificus Prof.dr. H.C. Hemker, volgens besluit van het College der Dekanen in het openbaar te verdedigen op donderdag 10 november 1983 des namiddags om vier uur precies, in de aula van de universiteit,

door

Raphella Sohier

geboren in Edinburgh, Scotland 
Promotores: Prof.dr. H. Philipsen

$$
\text { Prof.dr. J.J.C.B. Bremer }
$$

Referenten: Prof.dr. M.M. Leininger, Wayne State UnIversity, Detroit Prof.dr. W.H.F.W. Wijnen

Manuscript: Anke Schmitt-Muit Graphic design: Guus van Rooy Printing: Ben Meerstad 
"To grasp concepts which for another people are experience near (Kohut) and to do so well enough to place them in illuminating connection with those experience distant concepts that theorists have fashioned to capture the general features of social life, is clearly a task as delicate, if a bit less magical, as putting oneself in someone else's shin."

Clifford Geertz, $1977: 482$

this work is offered to:

Alice Dan

Carilee A. Hogan

$\&$

Bill Holzemer 

TABLE OF CONTENTS

PREFACE

PART I FRAMEWORK FOR THE STUDY

Chapter 1. General Information and Background

1.1. Theoretical Directions

1.2. Discussion

1.3. Conclusions

1.4. Research Directions

Chapter 2. Introduction to the Domain

2.1. Introduction

2.2. Contextual Literature in the Area

of Culture and Cognition

2.3. Gender Identity in Childhood and Beyond

2.4. Socialization

Chapter 3. The Study

3.1. The Data

3.2. Setting

3.3. Sample

3.4. Analytic Approach

3.5. Conceptual Frame

3.6. Data Analysis

3.7. Validity and Reliability 
PART II EMERGENCE OF A THEORY OF GENDER IDENTITY IN A PROSCRIPTIVE SUBCULTURE

Chapter 4. Zion in Profile

4.1. Zion

4.2. Religion 1s Marriage and Family

4.3. Religion, Family and Childrearing In Mormonism

4.4. Early Enculturation

4.5. Summary

Chapter 5. Ideal Profile of the Saints 75

5.1. The Saints 75

5.2. Collective Sociallzation 78

5.3. Role Status 81

5.4. The Unmarried Members 84

5.5. Masculinity and Femininity 87

5.6. What the Ideal Saint is Not 89

5.7. Summary 93

Chapter 6. Folk Bellefs in Zion 95

$\begin{array}{ll}\text { Chapter 7. Soclal Responsibilities } & 108\end{array}$

Chapter 8. Findings

8.1. Demonstrating Association in the Data

8.2. Discussion

8.3. Triangulation 130

8.4. Results of the analysis 134 
8.5. Meanings

8.6. Conclusion

144

8.6.1. Implications of the study

144

8.6.2. Limitations of the study

145

8.6.3. Future Study Directions

SUMMARY

SAMENVATTING

B IBLIOGRAPHY

APPENDIX A

163

APPENDIX B

APPENDIX C

174

APPENDIX D

APPENDIX E 


\section{PREFACE}

Many people assisted me in the long process leading to this day. I would like to mention Dr. Professor Hans Philipsen and Dr. Professor Joost Bremer, Promotors. They offered constructive criticism, practical assistance and kind support. Dr. Professor Madeline Lelninger, long time friend and mentor, encouraged, stimulated, and supported through the years, and served as external referent for the dissertation. Dr. Professor W. Wijnen, internal referent, brought the expertise of an experienced pedagogue to the evaluation task. It was George Evers who first suggested that I complete my doctoral work in the Netherlands, and I must credit him with that "brilliant" idea.

Dr. Professor Virginia Oh1son, who directed my work at University of Illinois, and Drs. Alice Dan and Bill Holzemer, were all invaluable at various times.

Mrs. Naomi Qufgley, secretary at University of Illinois, and Mrs. Anke Schmitt-Muit of the Rijksuniversiteit Limburg, offered so much kind assistance that they deserve mention.

Last but by no means least are my family in the United States, Dr. and Mrs. Arnold Dood and their children. They all continued to support without critfclsm, what seemed an unending task. There are also many dear frlends who warmed me through difficult times. Speclal are Carllee, dear Sarah, and Tomas who were al1 there for me when I needed them. Jan Dee proved herself a kind sister who offered friendship at one of the worst moments.

It is my hope that in my great joy and sense of achievement each of you will find the expression of my love 
and gratitude.

Financial support during the first two years of the $\mathrm{Ph} . \mathrm{D}$. in nursing program at University of Illinols at the Medical Center, Chlcago, came from a National Nurse Traineeship; Unlted States Department of Health, Education and Welfare. 
PART I

FRAMEWORK FOR THE STUDY 
CHAPTER 1

GENERAL INFORMATION AND BACKGROUND

Sumarizing Theories of Culture and Personality LeVine (1973) states that there is a general position among theorists that linkages exist between early childhood experiences and eventual adult behavior. This position leans heavily for its definition on psycho-analytic thinking. In the work of Erikson (1968) the same idea is reflected as to the linkage of childhood experiences in an earlier fase to the child behavior in a later one.

Anthropologists also express the knowledge that parents expect their early enculturation efforts to be reflected in the values and beliefs expressed by their children when they become adults (Middleton, 1970). However, Margaret Mead (1976) signaled the increased difficulties which attend the soclal transmisson process. She even questioned the utility of the effort in a period in history when the rapidity of change may invalidate the exchange. The world of contemporary chlldren accompaniled by the exponential growth of technological information is such that parents have 11ttle experience of the knowledge which their children need. The child world experienced by parents and children respectively resemble each other less and less during the last centuries and maybe even decades. Parents acknowledge awareness of rapid change in the world but nevertheless they continue to teach their children out of their own store of experlentlal knowledge apparently convinced that lessons in the area of beliefs and values are of great importance. 
plaget (1969) suggested that the reasons why sclentists fall to wncover the origins of adult behav1or lies in a fauty approach to the Investigation. It was Plaget"s conviction that only a consideration of the evolutionary or developmental phases of behavlor could supply clues to the linkages if they exist.

The investigator"s interest lies in the area of psychosexual development, the influence of socialization on that area of human development and the eventual linkages which may exlst between these particulars and the developtuent of same-sex erotic preference in adulthood. Taking. Piaget's position into consideration, the decision was made to direct a first investlgation toward a consideration of childhood socialization and its influences on early childhood psychosexual development. The primary intent of the study was a clarification of the nature of the process by which chlldren come to an understanding of their sexual selves. A secondary area was the development of substantive baseline data to support further studies contributing to the avallable Information about the origins of homosexuality.

\section{1. Theoretical Directions}

An exhaustive search of the literature leads to the conclusion that two contemporary theorles of psychosexual development in early childhood should be given serious conslderation in the study. They are, Social Learning Theory and Cognitive Developmental Theory. Soclal learning theorists postulate that children come to an understanding of their psychosexual selves through a process of Identification with, and imitation of same-sex role models. It is also maintained 
In the social learning school that a certain quantity and quality of contact between the adults and the children is neccessary for successful outcomes, (Mischel, 1970). Cognitive Developmentalists on the other hand propose that the understanding of gender 1dentity and gender role occurs as does all other learning, through a process of cognitive structural change and in a sequence of increasing complexity. (Kohlberg, 1966).

The theorles diverge sharply in terms of the child"s role in the process. Soclal learning theorlsts portray the person as one acted upon by the environment and the social actors thereln. The cognitivists on the other hand identify the child as the central actor in the process. The child is described as one actively engaged in structuring and restructuring knowledge in a dialectical process with the enviroment and the people in 1t. The soctal learning theorists declare necessary conditions which include the presence of key role models. The propositions offered by cognitive developmentalists on the other hand call for no more than a normal expectable enviroment in which the child is free to grow and learn at his/her own pace.

The social learning position places a greater responsibility on parents and creates a potentlal climate for gullt if the child, when mature, chooses directions or a life style contrary to the traditions of family and culture. Further, if the conviction is stressed that avallabillty of same-sex role models is "essential" to "normal" outcomes in adulthood, parents without partners are placed in a position of exceptional vulnerability.

In order to test the two theories outlined above, a fleld 
study of Mormon familles was designed. Mormon familles were chosen because $1 t$ is common that two parents are present in the homes, and, because they glve serlous attention to the question of chlldhood gender development and the preparation of the children for their gender roles.

In the subculture of Mormonlsm, male and female differentiation is stressed, and traditlonally sanctioned male and female roles are modelled in both quality and quantity. It was hypothesized that, Mormon chlldren should reach the measurable stages of gender development earlier than children In the malnstream population if the described artifacts were important in detemining outcomes, or, if the process was soclal in nature.

The formal hypothesis was derived from Social Learning Theory and read: "Children who are consistently and constantly exposed to same sex adult role models, expressing masculinity and femininity as operationalized in the Mormon subculture will reach the measurable stages of gender identity at an earlier age than children in the malnstream population."

The definitions and measurable stages of Gender Identity formulated by Slaby and Frey (1975) were adopted. The tool used to measure the childrens psychosexual development was also developed by them. It 1 s called "The Gender Constancy Intervlew" and it was used in 1 ts reviewed and revised form (1976).

Mormons were identified as the population for study because they exhlblt unusually unfform approaches to childrearing across families. Levine (1971) suggests that fleld situations in which constant conditions can be shown to exist afford a controlled frame in which to study those 
factors which vary. In the subculture of Mormonism, the consistency of the childrearing approach rests on the religous and secular belief system of the group. As in other non-conformist religlous sects, totalitarian and utopian socleties, an attempt has been made to remove the directions for child training from the sphere of individual cholce making it part of a grand design orchestrated by the church leadership, and centrally administered by the entire membership. The aim of the church, as of all simflar approaches, according to Levine (1971:57) is "l...to reduce haphazard and deleterious variations in personallty which are not at one with the control goals and aims of the soclety". Mormon parents acknowledge their reliance on the church for direction in childrearing modes. They are also aware that they approach childrearing with an unusual symmetry. They also express common expectations that their childrearing interventions will produce certain desired effects in adul thood.

Forty seven families took part in the study reported in Sohier (1981). The fantlies were chosen by means of a simple random sample, from a universe of families who met the basic criterla for inclusion in the study. It was required that: two parents be present in the home; that there be three or more chlidren, one of whom was in the age group to be studled; parents were required to be in "good standing" w1th the church (identifled by their local bishop); socio-economic levels determined on the basis of, a) family income; b) maternal education level and c) home ownership. Both parents, and one child between the ages of 42 and 90 months took part in the study. Equal numbers of male and female child subjects were 
included in the sample. The interviews were carried out in the homes of the subjects. The investigator carried out all of the 1nverviews personally. Pemission forms were signed by the parents agreeing that they and their child take part in the study. Three tools were used in the collection of data:

1. The parent questlonalre (Sohier, 1977)

2. The Gender Constancy Intervlew (Slaby and Frey, 1976)

3. Taped 1n-depth interviews with parents.

In addition to the three formal data collection methods, participant observation was carried out and ethnographic diarles were malntained.

The results of the Gender Constancy Interview were organized into stage and sequence by age and sex. A score for the rigldity of parental beliefs was developed and an F-test for individual groups was carried out between "Rigidity of Bellef scores and Ch11d Development Stages".

The taped Interviews were transcribed onto "Indeks" cards. Responses to each theme were identified using code numbers. Commonly recurring response patterns were identified and noted. Some of the verbatim material was used in the text to 111 ustrate points of interest, but the body of the qualltative data was stored for analysis at a later date.

The flndings (Sohler 1981) showed that contrary to expectations mirrored in the hypothesis the child subjects tested considerably lower than children in the malnstream population. Fortyfive of the chlldren did respond in the stage patterns described by Slaby and Frey (1976). Two subjects responded in a non-stage pattern. The general result of the stage/non-stage patterning supports the findings of slaby and Frey which report an increased ability to respond correctly 
correlated with chronological age.

A belief score was developed to reflect and examine the relationship between the rigidity of parental bellefs and the gender constancy outcomes for the children. The resulting bellef scale ranged from 8.0 at the high end to 4.2 at the low end. Child outcomes were classified as being "within" or "without" the normal expectable range for age, based on the results of Slaby and Frey. Fifty five percent of the children fell outside of the normally expected range for age. Even allowing for random error this seemed a remarkable high proportion. An F-test for independant groups was performed to determine whether the children outside of the expected range were the children of parents with rigid beliefs about childrearing. The F-test proved significant at $\alpha=0.05, F=$ $2.09(\mathrm{~d} f=25,20)$. Appendix A contains two tables from Sohler (1981) showing the ordering and distribution of the Mormon children over the four stages of psychosexual development in comparison with the results of Slaby and Frey (1975).

\subsection{Discussion}

Children in general grow into adults capable of expressing themselves in psychosexual terms, among others, and of fulfilling their adult roles. This appears to be universally true no matter what mode the socialization takes, or the form of the soclety in which the child develops. However, it cannot be taken for granted that the child who understands his/her sexual identity by the age of seven or eight years will automatically evolve into an adult who chooses sexual behaviors which conform to the dominant cultural mode. 
Money (1976) allows for subtle variations of gender identity having some (as yet undefined) affinity with mischiefs of nature as complex as sexuality itself varlations whlch lean heav1ly on the early years of childhood for their subsequent definition. The "complex mischiefs of nature" to which Money alludes have been intimated in the results of recent studies in neurophysiology, genetics and hormonal processes. Relationsh1ps are now emerging between these and earlier ethological studies which, when applied to human belings, lend credence to the ldea that "nature's mischlefs" may produce varied expressions of sexuality in Instances where dissimilar environmental stimuli conjoin with them to evolve variations in apparently similar organisms.

It is possible to support these formulations on the basts of Plagetian theory. Plaget describes cognitive developmental phenomena arising out of a dialectical process which relies on potential in the organism and stimulus from the enviroment coming together at the "moment of readiness". It is then that developmental growth or change can take place. In Plaget's schema, progression of the child to a higher level of understanding $1 \mathrm{~s}$ not determined by environmental influences or by the blologlcal state, but occurs at the moment when all of the elements are in concert.

The child selects his/her experlences, structuring new knowledge in a balanced growth process. If this process is "allowed", the child will eventually be enabled to express himself/herself in terms of true identity or pure expression of self. Perhaps it is this of which Jacques Maritain wrote when he spoke of the "Intultion of belng". This study intimates a slowlng down of cognitive developmental processes 
in situations where rigld consistent conditioning practices exist. Whether or not a subsequent same sex erotic preference can be shown to evolve in persons who are slow in recognizing their gender affiliation is yet to be determined.

\subsection{Conclusions}

The evidence accumulated in the field study did not support the social learning hypothesis and was consistent wh the cognitive developmental theoretical position. While small children were observed to Imitate the male and female roles demonstrated by significant same sex role models, they tested far below the norm for children from the mainstream population.

When measured by the Gender Constancy Interview (S1aby and Frey, 1976), it became clear that their psychosexual development was slowed. The study findings reinforced the position that psychosexual development occurs as a function of congnitive structural change and in a sequential pattern. Bandura (1971) writes that "Cognitive functions play an especially influential role where retention over time is required." Thus, children who appeared confident of their sexual identity and the nature of their sex role tasks when they were in the presence of the models, were not clear about their sexual identity when tested.

The results of the Guttman scale analysis supported the findings of Slaby and Frey (1975). Mean stage scores and success on each question set increased with age. A relationship was shown to exist between the subject's age in months and the level of gender development, a finding consistent wilh that of De Vries (1974) and Slaby and Frey 
(1975). However, the hypothesis stated the expectation that soctal influences would accelerate learning if the learning process pas purely a social phenomenon. The evidence which emerged demonstrated a markedly slow learning pattern in $55 \%$ of the child subject. While the particulars of stage and sequence described by the cognitive developmental theorists was upheld, social influence appeared to intervene in a direction which was opposite to that hypothlze producing slowed learing patterns in a majority of cases.

\subsection{Research D1rections}

When the study described in this short summary was completed it was neccessary to declare that the study questions were answered only in part. The children who were slow in achleving an understanding of their gender identity and role, were further ldentified to stand in signiflcant-statistical relationship with parents who declared that they rigidly adhered to the bellefs and childrearing practices of the church of Jesus Christ of Latter Day Saints. Speciflcally identifled were the parents who expressed their bellef in consistently superlative terms.

The "RIgld1ty of Belief Score" was developed from statistical data. The result of the manipulations were clear. A relationschip existed between parental rigidity of belief and slowed psychosexual understanding of identity and role in the chlld subjects. Nevertheless, questions remained regarding the validity of the findings: did they in fact describe a "rigid" socialization process?

Kerlinger (1973) discussing the subject of measurement, draws attention to the fact that the researcher who has 
accurately reported the height, length and breadth of a table has said little or nothing about it. Whether it is constructed from orange crates or preclous wood, who uses $1 t$, where it stands, whether it is a thing of beauty or not; these and other questions remain matters of conjecture. For this reason, because an unexpected effect appeared to exist in the situation described, a second study was undertaken.

The subsequent study comprises the main body of the dissertation and takes the form of a qualitative analysis of the construct of Gender Identity in the subculture of Mormonism. Speaking of childrearing methods, Campbell (1971:517) "...the determinants are all sources of pressure, constraint, belief, and value that influence training decisions. Some are in the parent, some in the social system and some in the child". Further justification for the study is contained in Campbell"s observation that "Research into parental phenomenal fields has been fragmentary and incomplete" (p. 530).

The data analyzed in this study consist of verbatim material in the form of tapescripts, collected during the course of the first study and retalned for analysis at a later date. In conclusion, the results of the multiple methods and approaches have been combined in a triangular analytic approach directed at increasing the validity of the findings. 
CHAPTER 2

\section{INTRODUCTION TO THE DOMAIN}

\subsection{Introduction}

The 11terature ldentifies that parents or other culturally sanctioned caretakers in all socleties, strive to assist their childeren to become approprlate members of that culture. Levine (1971, p. 510) "They (the theorlsts) are generally agreed that early experience leaves permanent residues on the individual." The transmission of information may affect outcomes in ways which are unexpected. Many varlables interact modifying individual personality traits. The characteristics of the caretakers, and the value system of the soclalizing agents are thought to be important modifiers. It is through the soclalization process that children come to understand the expectation of their culture in terms of roles, privileges and obligations. Levine describes childtralning as "socially purposive". It tends to assure perpetuation of the culture to which the chlld belongs. Kloball (1974) also speaks to these influences:

Categorles of understanding are learned, utilized, verified, transmitted, even changed but their persistence over generations establishes them as a group phenomena. -. Their meanings do not come from the innate traits of the Individual but from relationships with the enviroment, particularly from participation in social groups. They are cognitive formulations of man's perception of reality (p. 131).

The unexpected results reported in the earlier study have 
moved the researcher to examine the links of cognition and culture surrounding the phenomena of interest.

The question of socio-cultural influences and their roles in psychosexual development in childhood is an important step in the attempt to identify links which may exist between childhood experience and adult erotic preferences. This study is an attempt to further illuminate this area of interest. Levine ( 1971) wr1tes:

It is parents who decide how to organize relations between environments and children, and we need to know much more about the cognitive and other bases for their decisions before we can understand how these relations are organized in culturally different populations ( $\mathrm{p}$. $539)$.

The first question being asked in this study relates to the "basis for cognitive decistons" mentioned above. What are the perceptions of gender identity transmitted by parents to children, in a subcultural group in which a high percentage of children exhibit an idfosyncratic cognitive developmental pattern (when compared with developmental rates in mainstream American chlldren)? Is the reality of their lives structured in such a way that it inhibits progress through the cognitive stages of gender development as described by Slaby and Frey $(1975)$ ?

The study presents a theory of gender Identity in a proscriptive subculture. The phenomenological data are permitted to express themselves, lllustrating the elements, Ifnkages, concepts, and core constructs, which comprise this reality in the minds of the members of the subculture.

Plaget (1952) described structural developmental 
dimensions of cognitive growth, and demonstrated their existence in middle class Western children. He used chronological age exclusively as a control measure.

Crosscultural studles seekling to examine Plaget's claims and using a varlety of cognitive approaches are extensively reported in the 1iterature. Greenfield and Bruner (1971) and others have sustalned Plaget's clalm that learning occurs as a function of cognitive structural change and in a sequential pattern. Plaget (1970) acknowledged that cultural influences might accelerate or retard growth patterns, in terms of chronological age of achlevement. He identffied "cultural values, and language", as intervening variables. There is an accumulation of evidence which supports Plaget's observation. (Bruner, Olver, Greenfleld et a1. 1966; and others). The studles of this nature reported in the literature have been carried out exclusively in non-Western cultures (Dasen, 1981). The results obtained by Sohier (1981) appear to be a single case of evidence of childeren in a Western culture, a large percentage of whom exhibit significantiy slow rates of cognitive development in the area of psychosexual development. The socletal group to which the chlldren belong has been 1dentifled as a "minortty" group, (Leone, 1979). Leone typifted his classification saying "Mormonism is a special way of thinking", (p. vi). It is fairly simple to demonstrate the minority status of Mormons but the group must be rightly classified as a "minority subculture", (Leininger, 1978, p. 127). "Subcultures are generally part of the larger cultural group but their distinctive ways of living make them a special group..." According to Webster (1975, p. 1158) "subcultural groups can be distingulshed on the basis of ethnic, regional, 
economic or social groupings exhibited in terms of behavior sufficiently different to distinguish it from others in the embracing culture". The members of the Church of Jesus Christ of the Latter Day Saints, or Mormons as they are popularly called exhibit several of these group characteristics: Individual Mormons are indistinguishable from other Americans in terms of economics, general education, and $11 \mathrm{ving}$ accommodation, but Mormons as a group are a distinctive people.

Group characteristics which set Mormons apart in America are their preference for concentration in the inter-mountain West or far Western States (Utah, Idaho, Arizona and California). Utah has a historical significance for Mormons which will be explained later; their uniform appearance as "clean cut", we11 dressed, middle class Americans; the 1deal, (falrly well observed) to abstain from alcohol and other stimulating beverages; their statistically significant high levels of wellness, which can be attributed to healthful living; and their unified devotion to family life and the work ethic.

Mormons have historically been stamped with "uniqueness and peculiarity" (Leone, 1979, p. 15). Their practice of polygamy in the early times set them apart from Americans in general, a state which became less noticeable after the Church outlawed polygamy in 1890. However there seems to be some evidence of a contemporary reaffimation or "re-creation" (Leone, 1979, p. 224) of this uniqueness. Mormon leaders have become the outspoken supporters of the political right in legislative issues encapsulated in the E.R.A. or equal rights of women in America. They have lobbied extensively to prevent 
abortion, dissemination of birth control information, sex education in schools, the entry of women into professions, and Gay rights. Turner (1966) discussed the strong attraction of right wing politics for some Mormon leaders, and predicted "that the rightists would probably not be able to gain control (of the church leadership) in the forseeable future" (p. 326). According to Leone we have passed over that horizon. It is his position that they may be actively involved, intentionally or unintentionally in recreating the mark of peculiarity which identifies them as a people apart from the malnstream of American soclety.

\section{2. Contextual Literature in the Area of Culture and}

\section{Cognition}

No 11terature has been uncovered by this investigator which deals specifically with cognitive developmental measures of "psychosexual development in childhood", and, the relation of those measures to the cultural background of the child subjects.

The Idea that culture influences thought, and consequently the evolution of identity, has been a recurring theme in anthropology, personality psychology and soctology for the last fifty years. Many theoretical explanations have been put forth in each of the disciplines as solutions to explain the processes Involved.

Blological or evolutionary theory has been applied to psychological and social organization (Hal1, 1965; Spencer, 1888). French soctologists around 1900, Comte, Durkheim, and others, stressed the critical role of social collectivity in determining the characteristics, and behaviors of the 
Individual. Levy Bruhl (1910) offered a generally rejected thesis, baged on "ontogenesis". He postulated that members of pre-industrial socleties had less developed minds ("primitive mentality") and were capable only of pre-logical thought. Boas was one of the early opponents of this view, one which elicited stormy and long lasting discussion in the scientific communty (Scribner and Cole, 1974). Boas rejected Levy Bruhl's formulations out of hand because of the lack of substantive evidence. The materials on which Levy Bruhl formulated this thesis consisted of second hand enthnographies and reports.

Surprisingly, Werner (1961) restated some of the formulations of Spencer and Levy Bruhl in an "orthogenetic" model. In his theory he described psychological developmental organization, but not the evolutionary, progressive mechanisms. Nor did the idea of development as a genetic or natural process do anything to clarlfy the relationship between culture and cognition. The early work of Kardiner and Linton (1939) and the later work of these authors with DuBois and West (1954) were directed to an examination of the "psychologlcal fabric" of soclety. Kardiner declared his position, that, no two psychological fabrics are alike. The group of soctal sclentists studied the inter-relations of culture and personality in historical and contemporary perspective and Kardiner made repeated references to the complexity of the task of describing and comprehending the personality of persons enculturated in cultures other than those with which the researcher $1 \mathrm{~s}$ totally familiar (1945:172). 
plaget (1941) developed an epistimology of knowledge Which has been called "The" most complete effort of all times to uncover the general laws of learning (Dasen \& Heron, 1981). Because Plaget"s intent was to uncover the existence of and describe the universal laws of learing which he postulated, he gave little attention to experimental design. He also seemed for many years to ignore the influence of culture, and enviroment, on human development. This fact caused a great deal of criticism particularly because it contrasted so strongly whth the "behavioral" school of his contemporaries (Watson, 1922: Skinner, 1961).

Despite the criticlsm, Plaget confined his naturalistic studles to middle class chllderen of Western background. His experiments were directed to small groups of children. Chronologlcal age was the major variable employed by Piaget to Identify developmental varlations anong the child subjects. He supported the position first taken by Boas (1911) that were no differences in the way minds work across cultures though material and classification systems may vary.

Lingulstic advances in anthropology have also contributed to the clarffication of some of the links between culture and cognition. Ethnosemantic analysis, which uses language in terms of meanings to explicate thought processes, or describe cognitive maps, has been used with success by several anthropologists. A good example 1s Spradley (1979). Spradley"s study of a group of alcoholics indicated clearly that only the members were capable of providing the clues to their cultural meanings. Spradley"s findings support the proposition that culture must be studied by some means which provides for 
Internal consistency or from an subjective as well as an objective view.

Plaget postulated that all learning occurs as a function of congnitlve structural change and in a sequential fashion. Kohlberg (1966) demonstrated that this princlple could be extended to the area of psychosexual development. In 1970, Plaget conceded that culture, education and language could reasonably be expected to retard or accelerate the chronological age at which sequentlal developmental stages were achleved. There is a large body of literature testifying that this is so. Crosscultural empiricists surveyed by Dasen (1981) have tested Piaget's theory in varying aspects and a growing number of non-Western cultures.

Plaget's approach is discussed in the context of crosscultural psychology by (Brislin, Louden and. Thorndike, 1973; LeVine, 1970; Lloyd, 1972; and Price Williams, 1975). These and many other investigators are engaged in empirical validation of Plagetian concepts, in crosscultural context. Out of this body of literature a general consensus emerges for the following aspects of Piaget's model:

The sequence of his developmental stages and the $1 \mathrm{r}$ structural properties (qualitative aspects) are sustained in the majority of studies.

The horizontal declages as found, do characterize most sample means - but do not flt all ind Ividuals, (the sequential appearance of the abllity to conserve quantity, welght and volume) and, the rate of progress through the stages or the chronological age at which the stages are attained show considerable inter-culture variation.

The last two points are of greatest importance in this 
study. The second, because a constant comprehenston of the sexual self in chlldhood seems to be attained at approximately the same time as the ablitty to conserve is achieved. The third polnt - that inter-cultural varlation has already been shown to exist - supports the purpose of this study which is to examine and evolve a theory describing the culture content of Gender Ident1ty in one Western sub-culture.

Greenfleld and Brunner (1971) discuss the question of culture value and its influence on cognitive development, suggesting as did Kluckholm \& Strodbeck (1961) that collective versus Individualistic value orlentations are clearly reflected in developmental patterning.

Valued attributes can be said to be reflected in cognitive responses. Kimball (1974) makes the point that categories of understanding (cognitive categories) are instrumental, functioning as keys to the culture in question for developing intelligence.

Development would seem to be related to culture content in a clear dialectic. Berry (1976) hypothesized and later demonstrated that people develop those specific skills useful for their survival in particular ecosystems. Dasen extended Berry"s model to Plagetian psychology predicting that "spatial concrete operational skills" would develop earlier and faster In Esklmo children than in a group of west African agriculturalists and that a third group of Australian aborlgines would emerge showing an intermediate rate of development. His prediction was sustalned (1975).

The large body of crosscultural research in the area of cognitive development has been surveyed by Greenfield and Brunner (1976) and Dasen and Heron (1981). No studies have 
been uncovered dealing with the development of psychosexual constancy and identity other than the classic ones with American child subjects (De Vries, 1969, 1974; Kohlberg, 1966; Miller, Roede11, Slaby \& Robinson, 1979; Salby \& Frey, 1975; Sohier, 1981).

As a summary it can be stated that there is a general. agreement among social scientists that relationships exist between the culturally defined aspects of early childhood education and the development of culturally acceptable personality characteristics.

Social transmission of information from generation to generation is differently organized in different cultures or social groups. Parents believe that their prior experience in Iffe can assist their children. They strive to transmit such information across generations. On the basis of the 11terature it can be assumed that culturally organized cognitions of parents are reflected in transmission models and materials.

The pauclity of literature explicating the cultural influences effecting psychosexual development in crosscul tural context suggests the need for continuling investigation in the area.

\subsection{Gender Identity in Chlldhood and Beyond}

Money and Erhardt (1972, p. 146) define "gender 1dent1ty as the private experience of gender role; and gender role as the public expression of gender identity". This definition implies a continum or relationship between the early childhood apprehension of self as a sexual being, and the total comprehension of the privileges and obligations which 
accompany the expression of one's sexuality in a given soclety.

According to Kohlberg (1966) the child's understanding of his/her sexuallty occurs as does all other learning, as a function of cognitive structural change and in a sequential pattern. The psychosexual developmental sequence has been classifled as follows:

1. Gender Identity: the ability to classify one's self and others correctly as male or female.

2. Gender Stabllity: the ablilty to demonstrate understanding of the invariance of one's own and others sexual identity over time, e.g. understanding that one's sexual 1dentity was the same in infancy and w111 be the same in adulthood.

3. Gender Consistency or Constancy: comprehending that one's sexuality is invarlant over situations, e.g. understanding that wearing "other sex" clothes does not change the nature of one's identity, (slaby \& Frey, 1975).

Empirical studies by De Vries (1969, 1974), Emmerich, Goldman, Krlshian and Sharabany (1977), M111er et al. (1979), slaby and Frey (1975), and Sohter (1981) sustain this theoretical postition establishing a growing body of evidence concerning the sequential nature of the process by which structural cognitive understanding of gender occurs in the developing child. It is posited that the chronological age at which such structures appear can vary, influenced by cultural values and language. Accelerated stage achievement has also been observed in children of high intelligence (Miller et al., 1979). 
In most cultures intensifled socialization for adult sexual roles occurs in the immediate pre-pubertal and pubertal periods of development. Cultures vary in the amount of attention bestowed on developing sexuality in early childhood. LeVine (1974) reports that childhood socialization in the area of sexuality is intense and dellberate 1 in all cultures. However, a general perusal of the literature on cultural values leads one to conclude that the amount of attention given this aspect of development in early childhood can be correlated with the hierarchical place accorded sexuality in the culture. Kimbal1 (1973, p. 130) speaking of enculturation says, "...In every culture there is some process of value accretion to transfer." It is clear that socialization for adult sex roles is not 1 ikely to be happenstance, but rather, directed toward the desired outcomes in each cultural group.

Green (1974) describes gender identity as, "a fundamental personality feature comprising three parts:

1. The understanding of one's maleness or femaleness

2. The expression of that factor in culturally sanctioned, and sex appropriate behavior, and;

3. The Individual's preference for male or female sex partners."

Erikson (1968) also considers that an understanding of one"s sexual identity is a componential part of personality development. He even suggests that those persons who do not experfence "heterosexual mutuality" in the course of their early adult development w11 have difficulty in achieving personality integration as adults.

Given the fact that the persistence of the human race $1 \mathrm{~s}$ a basic concern of the species; it is unlikely that cultures 
exist In which no attention is accorded to the preparation of chlldren for adult sexual roles. This study is directed to an examination of the phenomenon which attend the transmission process of sexual roles, in the subculture of Mormonism.

While there are examples in Western culture of non-related - but sanctioned soclalling agents they are few. Generally speaking parents are the primary socializing agents for Western children. Where this is not the case it is 11kely that the substitution has been provided by the parents of the child. Thus it is insured that those intervening in the child sociallzation process do so in a manner considered culture constant, and acceptable to the family. An excellent example of a role of this kind is that of the English "nanny". The "foster mother" is another similar Western example - but in this case appropriateness of the context of child socialization is culturally determined and socially sanctioned by the law, on behalf of the culture and society.

Mann (1981, p. 156) states "In socializing the Individual, culture does not work in the abstract but through 1 tg socializing agents - usually parents and stblings - the family group." "The structure of the family and the nature of the kinship system st111 influences the number of soclalizing agents with whom a child comes in contact, siblings, grandparents, cousins, aunts, and uncles, may all carry this title role dependent on cultural custom.

Parents are considered very important in the child soctallzation process. In some psychoanalytic and social behavioral theoretical approaches it is proposed that unless parents meet the chlld's needs qualitatively and quantitatively, the developing child will incur lasting damage 
to his/her personality.

The cognitive developmental approach denands much less of the parent. Piaget (1935) percelved the child as the one who sat in the control seat, taking from the environment what he/she needed to advance his or her learning. In this schema, the child's developmental needs are met through the provision of a safe, normal, expectable enviroment.

The nature of the environment is structured according to the values of the culture into whlch the child is born. Talking of the transfer of values from parent to child Kimball discusses "the dynamics of the experienced value" (1974, p. 130). Values give life color and dictate the factors of environment stressed by parents. Parents almost without exception express the belief that their prior experience can assist the growing child in preparing for adulthood.

\subsection{Sociallzation}

Berger and Luckmann (1967) define socialization as "the comprehensive and consistent induction of an individual into the objective world of a society" (p. 130). The objective world of a society is defined and determined by 1 ts adult members, on the basis of culture. Culture is then transmitted via the socialization process to each new member of the soclety.

The purposes of socialization can be defined as "the transmission of culture, and, the motivation to participate in established social relationship" (E1k1n, 1960, p.7).

In all cultures, the expectation exists that chlldren will eventually adopt the adult roles sanctioned by the culture and modeled by parents and other adults in the 
culture (Lansky, 1961).

Because helpless human infants are totally dependent on the whims of their caretakers, those signiflcant others, have from the earllest days a place of great importance in the 11ves of the children. Physical well-belng depends on parents, and a proliferation of studies on "bonding" surveyed by Klaus \& Kennel (1982), indicate clearly that love, comminicated in a warm, feeling fashion, is essential for uninhibited psychological development. Their dissoluble bond existing between parents and children has been the subject of 11terature, music, drama and film. There is little doubt that parents are primary in the development process of the child, and involved in transmlting to them those lifeways and bellefs which are cogent to them.

"Parents are constantly involved in a process with their children which emphasizes the value and bellef system which they embrace. And again, the parent engages in interaction situations which are regulated by soclal norms or rules as to what is appropriate and Lnappropriate" (Brown, 1960, p. 55).

Another author states "...soclallzation of the child is pre-adaptation to their future enviroments by incorporating into their learning the frutts of experience of earlier generations of adapting adults (Levine, 1973:503).

Postulating that learning occurs as a dialectical process between chlld and enviroment, it is reasonable to accept that varied environments, and a vartety of caretakers wi11 Influence outcomes, LeVine (1971) proposes that parental attributes Influence the child"s cognitlve development in serious measure: 
Since the cognitive structure of the parent determines in great measures how and to what extent he translates his selectlve environment into training experiences for the chlld it can be seen that the nature of socialization as a process mediating between adult experience and child training, is "dependent" on whether the parent's concepts of socialization are abstract or concrete, differentiated or undifferentiated, verbalized or unreflective, ideologized or rationalized, absolute or negativistic, coherent or disunified. Cultures vary widely on dimensions of parental cognition. (p. 506)

The terminology of this statement implies a leaning toward the soclallearning position which is unusual in LeVine's work. But elsewhere, clarifying his "psychology of individual influence of the child on the parent".

The decisions about how to train a child are determined by a variety of variables, e.g. sources of pressure, belief, values and constraints, all of which influence outcomes. Some arise out of the parents personallty and some in the behavior of the child with whom he or she interacts. (LeV1ne, 1971)

Implictt in this statement is a reinforcement of the dialectical nature of the soctalization process as described by the cognitive developmental school.

There are many reports in the literature of enculturation practices directed toward the vitalization of specific personality characteristics. These reports lend credence to the idea that value transfer from generation to generation is common. A classical example is found in the Hopt who encourage In their children the "good heart" valued in Hopi culture 
(Eggan, 1963). Jewlsh parents in the Bastern European Shtet1 commuties encouraged their sons to become educated because a gentle, learned man was valued as one of the "beautiful people" (Zbrowsk1 and Hertzog, 1952). Contemporary examples of the transmission of culture including socialization of values Lnclude (Glittenberg, 1977; Kendall, 1978; and Leininger, 1977).

In America it is customary for parents to provide children with relnforcenent in terms of monetary rewards for dolng chores - a practice which might be interpreted as a symbolic effort to train the child in the "work ethic" so valued by Americans. All cultures have valued personality characteristles and most parents strive to transmit these values to thelr children. The question the study poses 1s: how Influential are the value cognitions of parents on the developing cognitions of the child? Kimbal (1974, p. 146) writes about this subject:

"Cultural perspective (of parents) provides the screen through which early expertence is filtered and interpreted." It is then, reasonable to posit that parental perception of exlatential reality must be reflected in or influence the child's developing understanding of his or her world, and his or her place and role in that world, modified though they are by the nature of the child.

To conclude: there $1 \mathrm{~s}$ strong evidence in the literature that parents belleve their cultural attitudes and beliefs are transmitted to thelr chlldren via the soclalization process and Influence their adult behavior. 
CHAPTER 3

THE STUDY

The purposes of this study are:

1. To generate a substantive theory which explains the phenomena of Gender Identity in the subculture of Mormonism.

2. To contribute to the existing knowledge in the area of Culture and Cognition.

3. To demonstrate construct validity of the relatioship between Parental Rigidity of Bellef and slowed Psychosexual Development in a majority of the child subjects in the study.

In an attempt to describe, analyse, and theorize about the cognitive construct of Gender Identity, as it is perceived by the members of the Church of Jesus Christ of Latter Day Salnts, the study will approach the subject from subjective and objective directions. Kimbal1 (1974, p. 131) advises:

Although categorization as a cognitive process and cultural device is universal, the kind and substance of the categories exhibit great varlation from one soclety to another. Hence, the mode of thought for each society must be examined through its own $10 \mathrm{~g} 1 \mathrm{c}$.

In order to reflect this point of view the qualitative material has been analyzed following the method developed by Glaser and Strauss (1973). 
3.1. The Data

The data comes from several sources. The main body was collected formally and informally during a three month period of fleld research in the state of Utah, U.S.A. The phenomelogical analytic method used in this study (which will be explalned in detall later) not only allows but encourages the utllization of many sets of data, many sources of data, and, repeated contacts in order to obtain rich descriptive, explicltive material. For this reason, the main body of the data is supported and extended by other materlals.

In the course of the field experience ninety-four parents (married couples) were intervlewed in depth, on tape. Five statements taken from The Parent Questionnaire, (Sohier, 1981) (Appendix B) were used as probes in order to elicit more speciflc information about the values and beliefs surrouding questions of childrearing related to sexuality; the percelved source of bellef and value which supports the childrearing methods; and the expected outcomes of childrearing in adulthood.

Before the inverview a permission form was presented and signed by the parents. The subjects were also assured of anonymity in reporting the data. The permission form is included as Appendix C.

The ninety-four Mormon parents were 1nterviewed in dyads Immediately following their response to "The Parent Quest1onnalre", but before they had an opportunity to discuss the content with each other.

The Interview took place in the homes of the subjects. In all but two cases they were conducted in the evening following dinner, when the families were reasonably relaxed 
The interviewer initiated the discussion by drawing attention to the similiarity or variation of their responses to the statements, e.g., "Goodness! This is very interesting - you each responded to this statement in exactly the same way." The investigator then rephrased the statement with a request to the parents to tell the interviewer more about their understanding of the subject of the statement. In most cases, little subsequent prompting was required. Most couples were fascinated to find they thought exactly alike, or quite differently about the subject matter under discussion.

Prompting when necessary took the form of indirect questions or clarifying statements. The inverviews lasted from forty minutes to one and a half hours with a mean of sixty-five minutes. All interviews were conducted by the investigator.

Following the interview the materlal was transcribed onto "Indeks" cards to assist comparison and classification. The transcription was carried out the same evening or the following morning. Only one interview was arranged per evening. This approach permits a "clean comprehension" of each set of data and facilitates the identiflcation of broad scale categories in the data. It is however economically feastble only when the fleld worker is able to give all of his/her time to the research process.

In addition to the transcribed interviews the data also comprises information collected in the following ways and circumstances:

1. dafly enthnographic diaries

2. census data

3. newspaper c11ppings 
4. I1terature on Momonism (both popular and profound)

5. scientific 1iterature in the areas of interest

6. participant observations: interview notes (made after Informal conversations with, e.g. waltresses, gas pump attendant, local pharmacist - people in short who were not Included in the random sample of familles but who were able to offer data which enriched the perlod of participant observation)

7. attendance at church services, Sunday School, Woman"s Rellef Soclety and Sunbeams (pre-school church education)

8. attendance at "family home eventings" (the significance of this w111 be explained)

9. attendance at social events, e.g. The Utah Symphony Orchestra (as the guest of one of the participant fam111es)

10. acceptance of dinner invitations and invitations simply to "spend some time with us" were accepted and offered a rich source of data

11. vistts to the symbolic centers of Mormonism, e.g. the Temples at Manti and in Salt Lake City, and to the Salt Lake Tabernacle, as a visitor, sometimes as an attendant at services, and also to 1isten to and observe the phenomenon which 18 the Mormon Tabernacle Chotr.

These materials together form the orginal body of data collected in southern Utah.

In the constant comparative method, there 18 no demarcation line between data collection and analysis. Data gathering continues throughout the analysis as the researcher 
deems recessary. The purpose is to search for clarifying pleces of data, wherever they may be and what ever thelr nature. The method is concerned with generating and plausibly suggesting many properties and hypothesis about a general subject area. For example, during the most recent phase of the analysis, additional interviews with members of the L. D. S. church in Michigan were sought in order to clarify questions of principle or bellef which arose out of the data. After the interviews the new information was incorporated into the data.

A free interplay between relevant literature sources, actual collected data and observational materials is, customary, sanctioned, and considered essentlal to the generation of grounded theory following the methodology of Glaser and Strauss (1967) and Schatzmann and Strauss (1973). "The field researcher is a methodologlcal pragmatist. He sees any method of Inquiry as a system of strategles and operations designed - at any time - for getting answers to certain questions about events which interest him(her)", (Schatzmann \& Strauss, 1973, P. 7) and further: "Meanwhlle he correlates what he sees with what he hears from those persons who stand in different relationships to each other and the whole situation. The observer is then able to develop an anbstract, logical, and empirically grounded representation of the observed situation" (p. 13). The constant comparative method enables the Investigator to create another 11nk in the logical theoretical explanations which already exist in the study area. In order to achfeve this end some variation must exist in the nature of the data, the kinds of data, and the methods for assembling the data. 


\subsection{Setting}

The population identified for this study resides in two countries of southern Utah. Forty-seven familles took part in the project. The sample was selected from familles with three of more chlldren, where two parents were residing in the home, and from parents who were recognized as practicing Mormons in good standing with their church.

Socioeconomic status was controlled on the basis of family income and maternal educational level. Both parents and one child between the ages of 40 and 90 months took part in the study. An attempt was made to include equal numbers of male and female children in the sample.

\subsection{Sample}

A simple random sample of families was selected in the following way. On the basis of the school records, all famflies in the area who met the basis criteria were placed on a prelininary 11st. The families were then divided into three groups, those with children in the youngest, middle and older age groups. The lists were then subdivided into those with male and those wh female children. Each family's telephone number was written alongside their name. Using the last two digits of their telephone number as a guide, the researcher then entered a table of random numbers selecting an equal number of families from each group. The families identified in this manner were then approached by telephone and Invited to take part in the study.

The local newspaper had carried a short article about the presence of the researcher in the valley, the purpose of the study and the fact that families would be approached to be 
participants. As a result, most of the famflies had a cursory knowledge of the study before they were approached. Only two families declined to take part in the study and no families withdrew after the study had commenced. After each family had taken part in the study, a formal thank you letter was sent by the researcher.

\subsection{Analytic Approach}

The "Constant Comparative Method" (Glaser \& Strauss, 1967 ) is a phenomenological approach to data analysis. It is a theory generating method, which rests on the process of sclentific induction. It allows the phenomena in the fleld of interest to speak for themselves through an interplay of subjective perceptions (native) and objective observations (field researcher and others) balanced against existing theoretical explanations in the literature.

The method has proved invaluable for grounding theory from specific areas which rest in complex flelds. (See studies by Benollel (1977), Bozett (1979), Degner, Beaton, and Glass (1981), and Strauss (1965)) According to the authors the method may be used for generating descriptive materlal, descriptive analysis or grounded theory. Two levels are described, "substantive" and "formal". The f1rst refers to studies whose purpose is to examine soclal areas such as "patient care" or "soclal organizations". The formal. development is one which explains or further clarifles a formal or theoretical area of soclal Inquiry, such as "stigma, status congruency, deviance" or as in this case the cognitions surrounding sexual identity in a given group. 


\subsection{Conceptual prame}

The "Constant Comparative Method" rests on the thearetical assumptions of "symbolic interactionism" (Mead, 1938). Mead 1 s 1dentifled as the major theorist in the evolution of symbolic interactionism but many other scientists contributed to this development, among them, J. Dewey, W. James, James M. Baldwin, Robert Redfleld, Louis Wirth and more recently Erving Goffman. A glance at the list shows that the symbolic interactionist view arose out of the combined thinking of social scientists from several disciplines although 1 ts crystallization is always attributed to Mead.

The theoretical model was named "symbolic interactionism" by Blumer (1937). It is formulated on the following propositions:

1. That human belngs act toward things on the basts of the meanings things have for them.

2. The meaning of social interaction derives out of interchange wth other members of one's society or group.

3. That these meanings are handled in and modified through an interpretive process used by the person in dealing with the things he/she encounters. (Blumer, 1969, p. 2)

For the purpose of this study we accept the first proposition in terms of a general pre-supposition. The second and third propositions are amalgamated because the interplay of the two is an intimate one according to the Investigator. The interpretation of meanings takes place as a result of a dialectical interchange between the human organtsm and the enviroment. From earliest infancy the child's environment is 
structured, controlled, and interpreted for him/her in terms of culture, by caretakers. But, this dialectical interchange is further modifled by the perceptions of the person who receives and relays communiques to the child whether they concern rational, concrete, or affectual domains of human existance. Secondly, the input of the caretaker is also modified in contact with the nature or personality of the receptor.

The position of symbolic interaction is then that "the meanings things have for human beings are central in their own right" (Blumer, 1969). Blumer ends his essay on the theoretical position of symbolic interactionism by requesting that researchers "...respect the emplrical world and organize a methodological approach that reflects $1 t^{m 8}(p .60)$. The constant comparative method meets these criteria.

\subsection{Data Analysis}

An open coding system is used for analyzing data in the constant comparative method. In this particular study the first level of analysis was carried out during the field research period. Broad categorles of like statements were identifled while they were belng transcribed from the tape to "Indeks" cards. The broad categories are identifled by comparing every card with every case which has gone before, and those with each case which comes after. Similar and different statements were identified and numbered to facilitate their retrieval. The "Indeks" system simplifies this task, as does the utilization of a word processing computer.

The task of reducing the data to the recurring major 
ched in the following way.

slm1lar character were grouped together from the Indeks cards to worksheets. Each Ws is part of a continuous process of ast. Each fragment of the data is sifted, fled, it is compared and contrasted with 7 entered in the category and becomes in erial for the elements which follow. Some re than one category. In this analysis, a frequently belonged in categorles which :hey also belonged in the general category hey were of a religous nature. The process ntrast continues unt11 all of the data has ind no new evidence of the same nature

ise of categorlzation, comparison and more than 2000 statements. The task of ng themes begins at this point. As the Lt becomes evident that some statements are cal application of the process of contrast Ices the mass of material and leads to a racterlzes the true nature of the data. phase, thirteen categories emerged:

8. Social resposiblities

9. Right principles

10. Attitudes about homosexuality

11. Traditional roles

12. Adult expectations

13. Destiny 
Notetaking is an important part of the analytic process both during the data collection and the analytic phases. Working notes are transferred from the data notebooks to the analytic worksheets wherever they act as clarifiers. New notes are also made as a part of the continuous process whenever an important thought or idea relating to the work in progress arlses. These notes assist in the task of synthesis.

Schatzmann and Strauss (1973, p. 99) advise researchers to keep notes of three kinds, "theoretical notes", (T.N.s), whenever a plece of empirical evidence relates itself to another segment to the emerging theory or seems related to explicative aspects of extant theory, or just a note to research an apparently related thought - in the 11 brary. "Methodological notes", (M.N.s) give information about how one got information, where or any interesting related information. "Observationa1 notes", (O.B.s) which might be anything one may have seen, heard or experienced in the fleld, e.g. the manner in which one Mormon mother breastfed her infant in my presence, demonstrating her sexuality.

Bozett describes the analytic process thus: "...the researcher compares data to data, and concept to concept, and category to category. He/she compares concept to category, and concept to category to data (1979, p. 45). Some categories fall away. This can happen in two ways. First because they end up having very few entries, and secondly because they turn out to be 1rrelevant - though the second is less likely. In the first case - close scrutiny may show that the 1 tems fit in another category. It is also up to the researcher to define criteria and to decide whether or not the 1 tems have relevance for the study and to retaln or discard them. It may be 
necessary to collect another example of like data or ask subjects in the fleld to discuss the matter futher so that the researcher can verffy the existence of that particular concept and 1 ts importance to the body of data. When the items no longer clarify (because that concept had already been Incorporated and when no new data can be found the categories are sald to be "theoretlcally saturated" (Glaser \& Strauss, 1973). Categorles collapse, and as one moves from one category to another, relationships present themselves in a $10 \mathrm{glcal}$ sequence. This approach to data analysis is reflected by Campbel1 (1964) who points out that it is necessary to bulld a context of similarity before any two 1tems can be seen to contrast as different.

In the course of the analysis, it was necessary to arrange additional interviews to clarify some points of religlous bellef. For example, many of the subjects in the study used the term "right principles". It appeared again and again in the data, but it was used in many different ways. In order to clarify this matter an interview which lasted several hour was arranged with a Mormon, Identifled as an expert on church doctrine and interpretation.

The following entries are examples of the analytic worksheets at this level of analysis.

Category: Sexuality

I. D. No. 36

Statement: "Your sexuality and sexual style is learned as opposed to instinctual; therefore, children are affected by what they see."

Characteristics: Sexuality: learned, not instinctual; children affected. 
Properties: learning, effects

T.N. Social learning approach

Category: Traditional roles

I.D. No. 13

Statement: "I don"t think it hurts children to change roles, on the contrary I think it teaches boys to be tender."

Characteristics: Role change acceptable; teaches tenderness

Properties: nature of roles; tenderness

0.B. This is a very unusual point of view. So far there has been no emphasis of this kind referring to boys. Idfosyncratic T.N. (Non-traditional response)

Category: as above No. 9

Statement: "I followed the behavior of my father and tried to take his role."

Characteristics: Behaviors of my father. Properties: Traditional behavior

T.N. Social behavioral?

The work of comparing, contrasting and sifting the data for evidence of recurring content is carried on in this painstaking way and as the work proceeds, concepts emerge and begin to flow together via conceptual 1inkages. The categories coalesce and constructs emerge.

For example: "Mormon Family" was identified early in the process as a major concept, but "Eternal marriage", one of the original categories slowly presented itself in the character of the Indispensable property of Mormon family. "Childrearing" was also Identified early as a major aspect of the data 
content. But, many 1 tems from all categories eventually were Inserted in the category "Religous beliefs", because it became obvious that they had their origin in religion. The category "Ideal profile of the Salnts" emerged late in the analysis as a coalition of several of the original thirteen categories as we11 as 1tems from others. It became evident that a number of bellef statements were secular in nature and not religous and from this realization a new category called "Folk Bellefs" was formed. In this way, some categories collapse and the items are dispersed by inclusion in another more important conceptual category, and new categorles are generated.

Finally, out of the original thirteen categories, six major concepts could be ldentifled, as follows:

1. Rellglous Bellefs (relating to gender identity)

2. Childrearing in Mormonism

$\operatorname{Re} 1 \mathrm{ig} 10 \mathrm{n}$

3. Mormon Family

4. Folk Bellefs

5. Ideal proflle of the Salnts

6. Social Responsibilities

The first three major concepts form a significant relationship with the core construct Religton and the other categorles inter-relate with them. Conjointly, they describe the construct of gender Identity in Mormonism. The content of the conceptual categories and their interrelationships together, create a substantive theory of the cognitive construct and its operationalization in the subculture.

When it became clear that the categories were theoretically saturated, no new material emerged, and the categorles described themselves, the original 2000 or more 
statements were reduced to a total of 469 . These were typed on to small cards to facllitate the rellabllity sorts.

The final cards carried statements or phrases such as the examples below:

"Freedom to do things which interest children is important to them whether they are traditional or not."

"Visiting the sick is important to us."

"We strive for the fullness of the prlesthood."

"Rellgion and family are one."

"God will create larger family units in the next life."

"Some homosexuals are excommunicated."

"Children are brought into this world so that they in turn can become parents and enjoy children."

\subsection{Validity and Reliability}

The objective of the analytic method developed by Glaser and Strauss (1967) is the discovery of grounded theory. Its purpose is not to test extant theory. Schatzmann and Strauss (1973) address the question of validity and reliability and point to the jeopardy involved in defending qualitative research findings. It is their bellef that the strongest defense rests in the investigators conviction that he/she has sampled and sifted the phenomenological evidence. In this particular study the conviction surrounding the credibility of the data and evolving theory rests on more than conviction.

Kerlinger (1973) points to the difference between "soclal" and "scientific" outcomes in fleld research, suggesting that the great plethora of variables in the real world make it very difficult to demonstrate validity and reliability in field settings. Campbell and Stanley (1965), on 
the other hand, urge Investigators to attempt to maximize the valldty and rellability in field research by extending as many of the principles of experimental research as are appropriate, to fleld research designs.

The body of data analyzed in this study was collected concomitantly with data for an experimental field study, therefore, the sample was a random sample. The sample size is adequate, consisting of forty-geven families $\mathrm{X}$ two parents = ninety-four subjects.

\subsection{Internal Validity}

The flve statements used as probes were excerpted from "The Parent Questionnalre" (Sohler, 1977). The questionnaire was scrutinized for content validity at the time it was constructed. Two Mormons, graduate students in Anthropology at the University of Chicago, agreed that the tool did:

a) describe the universe stated,

b) have a high probability of elicting from the subjects the information required.

Secondly, four doctoral students at the University of I111nols - Chicago, were requested to group the 38 statements in the questionnalre into themes. Three persons lidentifieed the four themes which the researcher was attempting to convey and the fourth person identified a fifth category. The two "outsiders" were paraphrased and reinserted. A second sort produced four themes - this was consistent with the intention of the developer.

At the moment in the analysis where all of the statements had been inserted Into one of the categories and "theoretical saturation of data had been achleved", it was decided to 
attempt to establish some rellabllity figures to demonstrate internal consistency in the analysis.

It was essential to the task that the raters have a thorough knowledge of and background in Mormonism. Two academlcians who are promiment Mormons we asked to assist in this onerous chore. (See short descriptive vita Appendix D.) They kindly agreed.

The task was approached in the following way. Each rater worked separately with the investigator. The rater was presented with $81 \times 5^{\prime \prime} \times 8^{\prime \prime}$ cards. On each card was written the title of the category and its operational definttion.

Two requests were made of the raters:

1. To insert each item into the appropriate category.

2. To decide whether each of the statements described the thought of a majority among Mormons.

In sort number one the investigator decided: a) whether the concepts fit the items, and b) whether the content within the category described this particular Mormon universe.

In sort number two there was also an implictt second advantage. A smaller number of statements appeared to the 1 nvestigator to be idiosyncratic or unusual statements made by Mormons - and these were asterisked inconsplcuously by the researcher before the sort began. By asking the raters to identify majority and minority statements the researcher recelved: a) confirmation of her own impressions regarding frequency or likelihood of response, as well as her ability to percelve Mormon thought in general; and b) to Identify idiosyncratic or individualistic responses.

The results of the first sort are shown in Table 1 . In 
446 cases all three raters agreed on the categorization of the 1tems; in 23 there was partial or complete disagreement. In 13 cases two raters were of the same opinion. These 1 tems were categorized according to this partial agreement. 10 Items remained that could not be fitted into the six major concepts. The overall agreement can be expressed in a measure of agreement that has the same propertles as the well known assoclation coefficlent Kappa (PhIlipsen, Van Reek and Drop, 1983). When there is complete agreement between the three raters, its value $1 \mathrm{~s} 1.00$. In the case of complete disagrement the Kappa is -0.04 . The obtalned value 180.984 when scores of the raters are considered as "true values" and 0.949 when these scores are seen as only approximations of the "true values". This result means that the reliability af the categorization of the items is very satisfactory.

Table 1. Interrater agreement between the investigator and the cwo expert-raters in categorizing the 469 items

\begin{tabular}{|c|c|c|c|c|c|}
\hline Wajor Concept & $\begin{array}{l}\text { Agreement betwen } \\
\text { the 3. raters }\end{array}$ & $\begin{array}{c}\text { Di } \\
\text { betwe } \\
\text { and }\end{array}$ & $\begin{array}{l}\text { sagr } \\
\mathrm{n} \text { in } \\
\text { the }\end{array}$ & $\begin{array}{l}\text { ment } \\
\text { aptigator }\end{array}$ & $\begin{array}{c}\text { Find } 1 \\
\text { Categorizacion }\end{array}$ \\
\hline 1. Religious beliefs & 86 & & +9 & -10 & 92 \\
\hline 2. Childrearing & $\therefore$ & i & -- & -2 & 80 \\
\hline 3. Mormon fandy & 42 & $\cdots$ & +4 & $\begin{array}{c}-\infty \\
\vdots \\
\vdots\end{array}$ & 44 \\
\hline 4. Follo ba liofs & 110 & & +8 & -11 & 113 \\
\hline $\begin{array}{l}\text { 5. Leal protile of } \\
\text { the sabuts }\end{array}$ & 110 & & +2 & $-\infty$ & 100 \\
\hline $\begin{array}{l}\text { 6. Social } \\
\text { Responsibilities }\end{array}$ & 30 & & -- & $-\infty$ & 30 \\
\hline
\end{tabular}


The purpose of the second sort was to 1dentify those statements which were not commonly held bellefs among Mormons. Those statements Identified as uncommon beliefs among the Saints were inconsplcuously marked by the investigator before the sorts began. Out of the total of 469 statements, sixty items were identifled by all three persons, the investigator and the raters, as uncommon beliefs. The raters identifled a somewhat larger number than the investigator, but some confusion regarding the marking of the 1 tems in the sort with the rater II makes it impossible to report the numerical relations in this operation.

The results of the sort did conflrm the fact that the investigator is capable of differentiating in general the major and minor trends of Mormon thought, and those statements which are traditional or non-traditional in nature. 
PART II

EMERGENCE OF A THEORY OF GENDER IDENTITY

IN A PROSCRIPTIVE SUBCULTURE 

CHAPTER 4

\section{ZION IN PROFILE}

\subsection{Zion}

The members of the Church of Jesus Christ of the Latter Day Saints have a "revealed" religion. Joseph Sith, their founder, prophet, and original revelator was born in Vermont in 1805. He grew to adulthood in a time of great social unrest, and change.

The intellectual climate of the time supported a strong developing oral tradition, fed via continuous injections of new thought, introduced by migrants and immigrants. People were moving to new locations as a result of recent wars. There was a great surge of democratic feeling and strong rejection of the order from the 01d World. People were stimulated by the vast promise of a boundless land behind the frontler. All of these currents stimulated remedial solutions. Many of the solutions were reported to be of "Divine" origin. Brodle (1974, p. 15) states "...these pentecostal years which colnclded with Joseph Smith's adolescence and early manhood were the most fertile in Amerlca's history for the sprouting of prophets." Joseph Smith was apparently affected by the mood of the times.

He was confused by the proliferation of churches and the dissention between his parents about bellefs. His mother was religious, and she taught him to pray. It is reported that while he was praying for guldance about which church to join, he received heavenly visions. In the course of the visions he was instructed to found a church or,"... refound an authentic 
version of Christlanity" (Leone, 1979, p. 2). By 1830 Joseph Smith had founded the Church of Jesus Christ of the Latter Day Salnta.

The basic bellefs of Mormonlsm are to be found written in the Book of Mormon, a text which Joseph Smith is reported to have translated from an "ancient script", written on tablets of gold, delivered to hilm by the angel Moroni. One of the ldentifylng aspects of Mormonism 1s, that $1 \mathrm{ts}$ members belleve In "contemporary revelation". Throughout the life of Joseph Smith he claimed to recelve the living word of God through personal conversation with the Delty. The content of these conversations are (for the great part) recorded in two Mormon books called, The Pearl of Great Price and, the Doctrine and Convenants.

These three books together with portions of the Bible, accompanled by prophetic utterances and pronouncements form the basis and mainstay of the religion. The present day prophet is believed to be in direct spiritual Iine of succession to Joseph Smith the first prophet and consequently with God. The words of the contemporary prophet are, it is belleved, Insplred by God - who teaches through him, guiding and directing the entire church. The church also has a rich symbolic 11fe. (See Dolgin, 1979.)

The concept of "Zion" in Mormonism is two-fold. Zion is at the same time the free kingdom of the spirit of God, and the state of Utah. After a painful trek across the plains beyond the frontier, Brigham Young, (who became the church president following the murder of Joseph Smith) climbed the mountalns, and, high in the Wasatch range he looked down on the Salt Lake Valley and pronounced "This is the place". The 
small band of Mormons were looking for a safe haven from the religious persecution which they had suffered in the Mid-West, and they origlnally founded a religlous commonwealth whose philosophy was far removed from that of the United states. Leone (1979, P. 1) states "...this fast growing and internationally known church started as a utopian experiment in direct opposition to the United States. Throughout the early history of the church collective communism was practiced as a way of 1 ife and all persons were equal in terms of class. "Zion" thus has a plural meaning, first the religlous state of freedom and plenty promised by God to men of goodwill, and second, Zion is the Salt Lake Valley, the heart of Mormonism, Mecca and home of the heart for every Salnt.

Some major doctrinal differences set Mormons apart from the main body of Chrlstianity. They do not believe in "The Holy Trinity" as three persons in one God, but rather, as three persons. God the Father and God the Son are belfeved to have bodies, God the Spirit is just spirit. This polythelstic theme is mirrored in the dactrine of eternal progression which includes the belief that every Mormon possesses the potential to become a God in the Celestlal Kingdom. Whlle it is belleved that only the truly sanctified will reach the celestlal glory there are other lesser glories awating those who make sustained efforts to fulf111 the laws of God and the Church.

A second major distinctive aspect of the bellefs of the Saints is that they disavow the "Creation of Man", belleving rather that man existed in a spirit world before time, continues through time, and wil continue to exist in eternity.

Endowed with agency and subject to eternal laws, man 
began his progression and advancement in preexistence, his ultimate goal belng to attain a state of glory, honor and exaltation like the Father of spirits. During his earth Ilfe he gains a mortal body, recelves experlence in earthly things, and prepares for a future eternity after the resurrection when he w11 continue to gain knowledge and intelligence (McConkie, 1969, P. 238).

It is further belleved that the behavior and Iifestyles of the Salnts on earth can improve or (reduce) the quality of eternal IIfe.

Alongside these uncommon characterlstics of bellef, are also uncommon practices among the Saints. They tithe, (contribute) one tenth of all their earnings to the church. They do not use alcohol or stimulating beverages such as coffee or tea. They follow a program of healthful living including diet, fasting, and exercise which together has resulted in their identification as one of the healthiest bodies of people in contemporary America.

Mormons do not accept govermment welfare but provide an assistance (rellef) program for Mormons in need. They advise all Momon families to maintain a years supply of food in every home to sustain them in case of public or private emergencles, and they send thelr sons and daughters on mlssions around the world to spread the gospel of Joseph Smith. These proselyting efforts are pald for wherever posstble by Mormon parents.

Desplte the stringent demands of the church and the strangeness of the bellefs, the Church of Jesus Chrlst of Latter Day Saints grows and grows. According to The Church News, (March 27, 1982) membership in the church has reached 
the five million mark. Church publications do not talk of an attrition rate though opponents suggest that it is high. Nevertheless it is clear that the Mormon church is interpreted by millions of contemporary world citizens, as a viable symbol system, a ritualistic happening which provides for them a substant1al. "bridge" (Geertz, 1974) between ethos and warld view.

Dolgin (1979) attributes its strength to "a set of anthropological paradoxes".

The church is literalistic, yet encourages creedal independence, it is authoritarian yet values individualism; and it is organizationally stable yet adapts to the vicissitudes of social reality (p. 519).

To explain the whole content of Mormonism is not pertinent to this document, nor possible. Turner (1966) speaking of the church declares, "The Saints exist ... They have evolved a very complicated religion based on the teachings he (Joseph Smith) gave them. It amounts to a complete way of $11 f e^{\prime \prime}$ (p. 39). The major concepts of the religious bellef system are illustrated in the following theory because the dally life of the Salnts is, at the same time the life of the Church of Jesus Christ of Latter Day Saints. In the descriptive theory which follows the subjects explain, the concepts of gender ldentity as it evolves in thelr midst. The researcher offers the theory for examination, critique and testing.

\subsection{Religion is Marriage and Family}

Two concepts central to the beliefs of the Chruch of the Latter Day Saints and which exert a strong influence on the concept of gender identity in the Saints are "Eternal 
Marrlage" and the "Faml1y". All worthy Mormons marry for "time and eternity" in a secret ritual which takes place in the Temple. Many Mormon women go to the Temple for one of the few times in their Ilves at the moment of their marriage, and the "seallng" ceremony is one of great "symbollc" significance (Dolgin, 1969). Temple or "Celestial Marriage" is defined thus by McConkie:

The participating parties become husband and wife in this mortal 11fe, and $1 f$ after their marriage they keep all the terms and conditions of this order of the priesthood they continue on as husband and wife in the celestial kingdom of God.

Marriages performed in the temples for time and eternity, by virtue of the sealing keys restored by Elijah are called celestial marriages. (1969, p. 117)

A Mormon woman explatned the symbollsm of the keys in the following way:

The keys are not actual keys, not keys for opening doors In a literal sense, but more 11ke the key to understanding - a decoder - or the key to knowledge. In other words 11ving "Celestlal Marriage" as the church teaches is the key to eternity, (paraphased from a telephone interview with M.S. on July 22, 1982).

Many of the subjects in the study impressed on me the Importance of "Celestial Marriage", for the recelpt of blessings from God, the eternal safety of their families, and their own salvation and exaltation. While the Saints do not belleve that Celestlal Marriage on 1 ts own will get them Into glory they belleve that without it even a 11fe of righteousness and devotion, w11 not assure them of a place in 
the highest glory, or their status as Gods and Goddesses.

One of the mothers in the study explained, "Our children already take it for granted that they w11 get married saylng 'Our parents were married in this Temple, our grandparents in this, and our aunts and uncles in this or this one', celestial marriage is so intimately tied to our bellefs that it is inevitable that we plan and prepare for marrlage" (Case * 37).

An extension of the doctrine of celestial marriage is that of eternal familles, according to McConkie (1969, p. 273) eternal families always consist of husband and wife, and if they are blessed with chlldren, they too become members of the eternal fam11y.

Celestial or Temple marriage "seals" husbands and wives and their children to each other forever. It serves many purposes in the minds of church members: Because relationships are expected to extend Into the forever the quality of those relationships becomes very important; because a mortal existence is only part of a continum in eternal progression it is ideally taught that this life must be used by the Saint to improve his/her individual quality in order that the everlasting life may be enjoyed in one of the highest regions of glory, and if possible as gods and goddesses. It is taught that learning how to cope with, and manage 1 ife's problems $1 \mathrm{~s}$ a way of preparing for greater responsibllity in the next phase of progresston.

Among the saints the family is percelved as "the basic unit of the church and soclety" (McConkie, 1969, p. 273) and it is given precedence over everything else. Illustrating this a Mormon father said: "My religion tells me that the family is everything, and stands behind me to tell me how I can become a 
good father to my chlldren and husband to my wife. The family comes first, we would not go to a meeting or anything if a child was sick" (Case *5).

The concepts of marriage and famlly are one in Mormonism and together they form the core or central bellefs of the religlon. One of the statements in the original questionnaire (Appendix A.Q. *16) read "Religion is the most important thing in 1ife, and marrlage is the second". Theologically this statement is sound, but in the minds of the subjects 1 t was not possible to make such a division - they saw the dichotomy as artificial, declaring over and over that in Mormonism religion and marriage are one and the same thing. The religion teaches that without the family it is not possible to achieve the highest glory, and the prescribed famlly must be created through marriage. Case $* 21$ 11lustrates this point: "The family is the most important thing in $11 f e$. But, in our religion marriage and the family are so interrelated that you cannot sort them out In Importance." Another Mormon went further:

"My marriage and family are definitely more important to me than my religion, but if I am dolng one we11, the other w111 be in order because they are the same thing. However, if my marriage and family were not going we11 religion on 1 ts own could not compensate" (Case $* 47$ ).

For this woman it is clear that concepts of religion, marriage and family form a construct. Her husband enlarged on the subject saying: "The church on earth is simply a service agency for the family which is the primary unit of our relig lous structure" (Case *47).

The centrality of the concepts of marriage and family in Mormonism are further illustrated in two important articles of 
the religlous bellef system. The first, is the doctrine of "eternal progression" which teaches that souls are waiting in the pre-existance for mortal bodies which will enable them to prepare themselves for eternal glory.

The second is the command of God, originally made to Adam and Eve, to "multiple and replenish the earth". The Saints are taught by their religion to take both of these seriously.

"In our religlous belief we are on the earth for the same reasons as Adam and Eve, to replenish the earth, it is God"s w111," (Male, Case *26) and "Marrlage is everything, marrlage is eternal," (Female, Case *5) and yet another "Mormon people are family oriented, they believe that marriage and the family are so important" (Case *6).

The stress and emphasis placed on family life in Mormonism is historical. Speaking of the size of families and the nature of child care in the nineteenth century historians Arrington and Bitton (1979, p. 205) tell us:

"Marrlage was a blessing and a duty, children were welcomed in quantity, they were ralsed gently but formally by parents who were obligated to teach them religious truths and to train them for adult responsibilities. The family unit was at once, a school of experlence, a haven of affection, and a foreshadowing of and preparation for eternal blessedness. ...Mormons saw the family in their own religlous framework. For them, the family has always been the basic wnit for progress and foy in this 11 fe and in the life hereafter." In 1977 the Mormon birthrate was twice as high as the national average (Arrington \& Bitton, 1979, p. 395), and a twentieth century Saint explained it thus: 
"We plan to have four to slx chlldren (national average 2.3). You see we think of this as such an important thing. Our only purpose on this earth is to gain a body, live a proper and righteous $11 f e$ and return to our Heavenly Father. We belleve in Mormon doctrine that Satan wanted everyone saved regardless of what they wanted for themselves but that Christ the good son made it possible for us to come to earth with the power of free agency, and to choose what we want for ourselves. When you belleve that there are brothers and sisters of ours in the pre-exlstent life waiting for bodles in order to be saved, then it is no longer a question of ecology; enough water, etc. It is simplified into this question of a very short period which might be uncomfortable but which is preparing us for eternity" (Case *24).

Another Mormon father sald:

"I was ralsed in a family of ten children and if $1 \mathrm{t}$ was economically posstble I would be happy to have that size of family. It was a very happy fam1ly and we are st111 close and care for each other. I: would be glad that my chlldren could have the same kind of experiences" (Case *41).

The mother above went on to say:

"These little spirits are not ours they are simply given to us for keeping, a sort of stewardship, our religion teaches we have particular roles to play and that we must teach our children by our example. If we are not giving example we are not teachlng" (Case *28).

The traditional values of the nineteenth century family ring true for the twentleth century family. 
Marriage and family are together of major importance in the development of gender ldentity in the subculture of Mormonism. It is in the context of marriage and famlly that the developing child sees the male and female roles played out. These concepts form a major category in the emerging theory of gender identity in the subculture of Mormonism.

\subsection{Religion, Family and Childrearing in Mormonism}

Preparation for and interpretation of the traditional roles in Mormonism begin in early childhood. Since a majorlty of Mormons belleve that their souls were already sex typed in the pre-existence this is comprehensible. "Being guided by the idea that souls have always been male or female is a common bellef among Mormons" (Case *14).

It is also believed that one of the most important commands God gave his Salnts is to "multiple and replenish the earth" . Therefore Mormon parents have been taught, and belleve, that their children need to learn early in life, that their purpose is in turn to marry and found famllies. "Chlldren are brought into this world so that they in turn can become parents and enfoy children," (Case *19) thus preparing themselves for eternity according to Mormon bellefs.

The process of Salnthood begins on the day of the child's birth and continues till the day of his/her death. Each step of the way is charted with vigor and precision, by the church. Mormon parents are expected to obey the teachings of the church, incorporating the advice and admonitions of the General Authorlties into their daily lives. The church's position is clearly articulated in the childrearing methods of the Saints. 
Ch1ldrearing in the Church of Jesus Christ of Latter Day Salnts is not a purely personal matter. An extensive and complex educational system, developed and controlled by the central church body in Salt Lake City, is programmed, and distributed to Salnts around the world. Thus Saints in the process of becoming holy, are directed by the church, about every aspect of their lives, no matter where they may be. The program is not exclusively religious in nature but has extensive secular content also.

No detall of Mormon fam1ly life or childrearing is left to chance. While individualism is encouraged in church members - It is encouraged in speciffc and not general terms. Saints are encouraged and expected to develop their talents, and become self-confident, and self-reliant, thus, always, within the boundaries acceptable to the church, and to facilitate self-confident home management. Mormon young people are extenstvely prepared for marriage and family 1ife. (This will be discussed in the following section.)

In the Women's Rellef Soclety (orlginally founded to assist the poor) Mormon wives, young and old are exhorted to a prayerful approach to their obligations. The content of those obligations is further explained in secular terms. A mother explains:

"In the Women's Rellef Soclety we have mother education for childrearing, cultural enrichment lessons and mint courses on all kinds of homemaking skills, like, home nursing, and this year its home management, and we learn to sew, and can, and also do fun things like handcrafts" (Case *32).

and another mother says: 
"Our church offers all sorts of child guldance teaching In the form of the Rellef Soclety for women, and the department of children's services. People can get all kinds of help about how to rear thelr children" (Case *26).

Implicit in these statements is the acceptance of the church as a sultable teaching authority, not simply in direct spiritual areas but in areas of general welfare.

Mormon children learn early how to pray. They learn to return thanks to the Heavenly Father for their parents, without whose cooperation they might never have left the pre-existent splrit world and been given an opportunity to prepare themselves for glory.

Parenthood is a concept of awesome proportions for Mormon children and parents alike. Parents, admonished by the church, offer strong examples to their children. Asked to describe some of the exemplary aspects of the childrearing process, the parents in the study gave consistant responses:

"Teaching children right princlples and following those ourselves, valuing marriage as the most important step in IIfe and teaching chlldren to do the same; teaching boys they will bear the priesthood and girls they will bear children, teaching them that having a home and a atrong family is what they should strive for and showing them our commitment to those ideas in our own lives" (Case *36).

Latter Day Saints speak often about "right principles", those princlpies contained in the thirteen articles of fatth and supported by the church's interpretations of those articles of bellef. 
A practice to which the Salnts are exhorted by the church and to which most acquiesce 18 "Family Home Evenings". On Monday evenings there are no church obligations for parents, instead they stay home and fullfill the obligation of teaching In the home. Arrington and Bitton (1979, p. 295) describe it, "This is a regular activity that emphasizes participation by a11 members in education, discussion, and recreation." The church publishes a manual for this exercise offering guidance as 1 s customary in all aspects of family life and child direction.

The following description of a family home evening is taken from an enthographic entry: One of the famflies who sald I could attend their family home evening called on Saturday and suggested that I go tonight. The family have a very nice home. The gentleman is a builder and his wife has a bachelor's degree in child development.

The children were already in their pajamas when I arrived but they gathered in the living room. They were about 9 and 6 and 2 years old and their mother was pregnant. They sat on the couch and the floor and listened whlle Father read a lesson from the Family Home Manual. Then the kids asked some questions and Mother discussed the contents further. Af terwards they listened quietly while Father prayed aloud for grace and guldance, and revelation of God"s will for them as a fam $11 y$.

Afterwards the klds got excited because Father had promised to play a game with the older children. Mother Invited me to stay for dessert and went off to prepare $t$. I watched the kids and their father, they had a good time!

After a while the mother returned with pie and ice cream 
for everyone accompanied by large glasses of water. After dessert I safd my thanks and left. P.S. The pie was marvelous but I was longing for a cup of coffee. (Enthographic dlary, entry *72)

The childrearing process in the homes of the Saints may be interpreted by the parents to some extent but organized intervention in child care methods which arises in the central authority is constant. Mormon parents would be considered to fall in their duty to God, the church and thelr own children if they did not encourage them to take an active role in the organized activities of the local ward (partsh). "Many activities of the family center not in the home but in the ward meeting house, a kind of home away from home. It has often been remarked that the ward is an extended family..." (Arrington and Bitton, 1979, p. 296), and again "Through their weekday programs Mormons have been working energetically to see to it that much of the leisure time of their people wi11 be occupied in constructive church - sponsored activities" (Arrington and Bitton, 1979, p. 296). One mother sald:

"I would not want to bring children up in this day, and age, wtthout the assistance of the church. Because of our church organization we know at almost every moment where our children are, who they are with and what they are doing. We also know they are doing it with approprlate supervision" (Case *43).

The prophet exhorts falthful young parents to "chart a course" for their children.

In a properly charted L.D.S. home young people especially young men will plan a mission. With proper 
indoctrination, a boy is led to understand the course of his 11fe. He will be a deacon, a teacher, a priest, an elder. He w11 attend priesthood meetings and seminary, Sunday school and Mutual Improvement Soclety (M.I.A.) and do his home teaching. He w11 fill an honorable mission and get his education (university). He wil be married in the holy temple to a lovely Latter Day Saint girl who also has these same 1deals and whose life has followed a simflar planned course in home and church to prepare her to be a loving wife and mother. Parents should chart and guide the course of their children's lives in the early years. (K1mba11, 1969, p. 257)

It is evident that the expectations of the General Authorities are not only detalled, but rigld - the expectation is; that each step be taken in sequence, and elsewhere, President Kimball declares a disaffection for the practices of young people who reverse the flow by completing their secular education before fulfilling their "mission". Postponing marriage is considered even more damaging. Young marriages are encouraged, even if the young parents are both students. Nor are they advised to postpone their familes; it is advised by the prophet that they do these things simultaneously; marrlage, study and bables.

\subsection{Early Enculturation}

From earliest Infancy the Mormon child is sex typed. It is not surprising that in a culture in which marriage and family life form a major focus, great emphasis is placed on developing sex roles. In keeping with the 1dea of pre-existant gender fdentification there are many parents who believe that 
sex typification is complete before their birth. The mother in Case $\$ 12$ is an example:

"One thing I think about is what a male chauvinist $C$. Is. His sisters scold at him, and his father is gone from home a lot but he seems to have been born that way, he is such a boy" (Case *12),

and a mother of eleven children, expecting a twelfth, spoke out of her experience saying, "They are different from the beginning - girls can develop some skills boys do not." She 11lustrated this point by telling that one of her children, a three year old girl could already sew. She assured me that three year old boys did not have the same coordination, nor did she belleve "masculine" boys could or would want to learn such skills.

Whether or not the souls of Mormon children are sex typed at birth, Mormon parents work very hard at forging their male and female identities from an early age. Very small girls are being told as they play with their dolls that one day the do11 will be a real baby, and that they are one day going to be mothers themselves. And, little Mormon boys want to be just like Father. In Mormon families this role modeling and role playing appears much more studied than in the homes of malnstream Amerlcans. It does not seem be an integral, somewhat automatic aspect of childrearing, but, a studied effort at role differentiation from early childhood on, becoming more and more pronounced as the child grows older. Mormon parents belleve they can influence outcomes in terms of gender. "I think if there are strong masculine and feminine figures in the home that will influence how children turn out" (Case *25). "I think if they are taught to be women, that"a 
the way they w11 be, that will say dolng things the soclety sees as masculine and feminine" (Father, Case *11). Researcher: Could you describe what you mean by "soclety" please? "Wel1, Mormon soclety - the way we and the church think they should be."

The impression of strong sex differentiation surfaced in unexpected ways. One father sald: "My boys work with me all the time and they learn from me. I'm sure the girls do the same working with their mother in the howe. If kids like being with parents, they like to do things parents do, my boys show thatl" (Case *4). This father did not reallze that he had Implied 11ttle knowledge about what happened between mothers and daughters - simply presuning that it reflected what happened between fathers and sons, and had implicitly strengthened the picture of sexual differentiation of socialization modes for boys and girls.

While church leaders, and in turn parents, strive to keep their own lives and that of their children pure and chaste there is a strong overtone of overt sexuality surrounding and permeating the development of lives of the Salnts. In one Sunbeam manual (lessons for pre-schoolers) published by the church, there is a question which draws attention of the female child to the differences between her body and that of the 11ttle boys in the group. A Mormon mother who was a teacher in the group explained, "We are already teaching the children that all bodies are from God, that there is a boy body and a gir1 body and that they have their purposes", and her husband added:

"The figures which we hold in front of the children and the stories which we tell, teach the boys to seek after 
strong masculine models and the girls to reach out to feminine things. The storles are almost always about families and so they are taught what is expected of them" (Case $\star 24)$.

The mother went on to explain,

"You should hear what they sayl Even at that young age they understand a lot about sexuality. Of course we promote selfawareness by encouraging them to talk before the group and work for and get group approval for their personal appearance and efforts."

In one of the ethnographic diarles there is an entry describing a scene at the Tabernacle (church hall) in Salt Lake City;

"I went up to Salt Lake th1s weekend and on Sunday evening took a walk in the Temple square. Walking in the gardens I heard singing. Thinking it was the choir practicing I rustled over to the Tabernacle and went inside. Once inside I saw it was something else going on but declded to stay.

It turned out to be a "fireside" a sort of service for young adults in which they are admonlshed and advised. The people who talked (a Mormon couple) were advising the young people that it was time for them to start looking serlously for their Ilfe partners. I looked around at the very young people, fresh and beautiful, who were listening intently to this talk. They were all dressed nicely, the girls in long dresses and the fellows in suits. After a while one of the older gentlemen Introduced a young girl who got up and sang. She had a beautiful volce, but $I$ was distracted by her overtly 
sexual manner. It came across a 11ttle unreal! She was singling religlous words but in a way that suggested a movie set, she seemed to be selling her person rather than the song and I left the Tabernacle feeling sort of disturbed - it was so different from the church in which I grew up, this open discussion, admonlshing the kids to go "find" a partner, and the "very" sexual demeanor of the young girl. I don't yet understand quite what it means." (Ethno entry *39)

Time spent as a fleld researcher among Mormons soon makes it clear that role transference from one generation to the next is a serious business. The Saints in the study corroborated this observation very frequently. "Children learn through example. They see the roles of mother and father and know that these are the ways for males and females" (Male, Case *28). "We are very traditional, the mother does certain things and the father does certain things: We see a definite difference In the roles of mother and father" (Female, Case *28). Another couple echoed the same idea:

"We relnforce our children toward thelr masculinity and femininity. Girls get the preference and are taken care of, and boys must do the strong thing! Boys are never permitted to strike g1rls. Father 18 strict though loving, and mother is more lenient and more warm. We are constantly teaching them how they must grow up to be" (Case*5).

The Mormon parents in the study generally belleved that their interaction wth their children and the example given their child would exert a strong influence on their children's behavior as adults. Some of them expressed the firm bellef 
that they were persomally responsible for such outcomes. One father said: "Of course we are responslble for their behavior - they come to us knowing nothing - we teach them all they know" (Case *32).

Not all of the parents responded that they could be held responsible for outcomes, (in terms of behavior in adulthood) but all parents were convinced that the quality of interpersonal relations and the atmosphere of the home, together with the prescribed example of parents were indispensible in helping their children develop the desire for marriage and fam $11 y$, which would represent a successful socialization process.

"I think that the husband-wife relationship in a family is an important one which can affect the child's sexuality in adulthood," but the mother added, "I'm not sure that it is parental example which helps to solidify roles, I think that the parent child relationships are of primary importance and more likely to count. You see I think that example and religlous experience in a home $1 \mathrm{~s}$ of the same quality for all the children but Interpersonal relations are fust that - interpersonal" (Female, Case *37).

It is generally expressed by adult Mormons that transmission of role did take place for them, that they learned to place a value on marriage and famlly life because their parents did fulfill the churches teaching in terms of family care and chlldrearing. Two examples are given below:

"We enjoy family life a great deal. I think it has to do with the fact that family has always been held up to us as a desirable goal, and our parent familles have made 
famlly life so atractive. In my last job I had to work away from home half the time and I hated being away from home not Just because I missed L. but also because the ch1ldren and the two of us together make me very happy." And, his wife added:

"I'm quite sure that seeing a good, happy, and comparionable marriage set up, makes children want the same for themselves" (Case *16).

\subsection{Summary}

Throughout the entire life of a Mormon child studied efforts are made to transmit the knowledge necessary to the child in order to evolve the modal personality. It is further expected that the personality will be expressed through acceptance of traditional male and female roles. The church supports an extensive, and complicated, religious and secular educational program to this end.

As well as formal religlous education in the home, and at church, Mormon children also take part in organized secular activities from the age of two and a half years onwards.

Because Mormon parents value marrlage, home and family as the central focus of their religion, (one man sald they are "synonymous terms") (Case *21). They accept the interpretations of the church and the assistance of the educational arm of the General Authority of the church to help with the task of role transference across generations.

The content of childrearing in the Mormon subculture and the concept of Mormon Identity are 11nked to the perception of family and marriage and subsequently rooted in religious bellef. 


\section{CHAPTER 5}

\section{IDEAL PROFILE OF THE SAINTS}

\subsection{The Saints}

Joseph Smith the prophet concluded the thirteen articles of the Mormon faith (Append $1 \times \mathbb{E}$ ) by paraphrasing some words written by Paul the Apostle.

"We belleve all things, we hope all things, we have endured many things, and hope to be able to endure all things. If there is anything lovely, or of good report, or praiseworthy, we seek after these things."

The prophet offered an Ideal to the Saints which is a composite plcture of religlousity, goodness, and pragmatism. Committed members of the Church of Jesus Christ of Latter Day Saints in the eighties are still striving after these ideals.

Hallowe 11 (1955) wrote: "The native of the se1f considered in its conceptual component is a culturally identifiable variable. Just as people entertain various bellefs about the nature of the universe, they likewlse differ in their ideas about the nature of the self." and again "..the 1ndividual"s self image and his interpretation of hla own experience cannot be divorced from the concept of self that is characteristic of his soclety" (p.76).

The Salnts belleve they come into the world from a pre-existent spirit world and must use the experiences, opportunities and vicissitudes of this world to prepare them for eternity and eventual glory. One Salnt said: "Th1s life is a school, a preparation for eternity" (Case*13).

Living a holy life as it is prescribed by the church is a 
prerequisite for a happy solution in eternity.

"We must use religion as a guide in accomplishing our goals, be prayerful, follow the teachings of the church, use ourselves as the Heavenly Father intended; strive to be perfect, fulflling the roles God has given us and Iisten to and obey the prophet" (Case *15).

Another subject offered a composite plcture of the "ideal" Salnt:

"The 1deal Saint is prayerful, in good standing with the church, married, and a parent. He or she learns continuously both religlous and secular subjects, works hard, offers and accepts spiritual assistance from other worthy Mormons, accepts 11fe's difficulties as obstacles which when overcome help him or her in the struggle toward glory.

If the Stake President or Blshop askes for additional time for projects or assistance in church matters the Ideal Salnt w111 respond " (Case *3.) Over and above the religlous obligatons of church, home and family, and the contribution of one tenth of all their income to substain the church, the Saint in the process of "beconing holy 1 s expected to spend many hours a week in church related actIvity".

Turner sald of Mormonism that it is "complicated" and that it offers a "complete way of $11 \mathrm{fe}^{\text {". }}$. The Saints are exhorted to be religlous even holy and at the same time they are expected to be active in the church. They are not simply expected to be involved but to be actively engaged in the tasks of self-improvement and beling their brother's keeper.

A few of the subjects in the study either sald, or 
implied, that church demands on personal time are excessive in the light of their church identity as Saints and Americans. But, most do as much as possible without complaining. While one mother safd:

"We are told the family is the most important thing in 1ife. But, we get so involved in trying to do the things the church asks of us that $1 t$ can get confusing. The family is central (but I think sometimes that means to the church) for getting things accomplished. We hardiy have time left to focus directly on the family we are so busy in the ward" (Case $* 31$ ).

Splro (1957:58) identifies the components of collective education as follows:

1. A grand design on ldeology is made a part of the cognitive maps of parents.

2. Large segments of the educational program are removed from "direct" parental control and are a part of a larger organized educational system of the church.

3. Parents are ut11ized as part of this educational scheme so that a continual indoctrination of purpose and intent continues in tautological form.

Mormon parents are intimately involved in perpetuating this tautology. The demands of the church in terms of time are seen as a barter by most parents. They get so much out of the organized efforts that they feel their input is justified. Sometimes the church demands seem extraordinary. Occaslonally, a prominent Mormon may be requested to abandon promising career to take a position in church government or education. The 1deal Saint will not refuse, despite the fact that the economic progress of his family will most certainly be 
compronised.

5.2. Collectlve Soclalization

The church is a patriarchy and this organizational form 1s carried Into the family. "True family organization is patriarchal in nature" (McConk1e, 1969, p. 273). The power of the patriarchy rests in the priesthood. All Mormon men are called to be priests, and all worthy males are ordained. There are two levels of priesthood. The Aaronic and the Melchisidek priesthood. The second is more powerful. Much of the preparation of boys and young men for the eventual roles of husband and father are tled into the priesthood calling.

Preparation for the priesthood begins at age eight and the young man becomes a prlest between sixteen and nineteen. He 18 taught very early, that in order to achleve the fullness of h1s priesthood he must marry and found a family.

The prophet writes: "Exaltation in the celestial kingdom w111 be granted to those only who enter and falthfully observe the covenant of celestial marriage" (Kimbal1, 1969, p. 243).

The couples in the study spoke frequently about the "fullness" and the "blessings" of the priesthood. One mother sa1d:

"Some women in the church resent not having the priesthood but I don't. I can always have the blessings of the priesthood from my husband. I don't feel second rate because our religion teaches that without me he could never reach the Celestial Kingdom" (Case *14). Reaching the Celestlal Kingdom is the ultimate goal of the religlous bellefs of the Saints and $1 t$ is this that Mormons mean when they speak of the "fullness of the priesthood". 
Another mother talked about patriarchal blessings. Saying:

"The blessings are real. We don't talk about them a lot because people scoff at us but they are real. There have been occastons when my husband has walked in here and found me overwhelmed by the responsibilities of caring for a family of five, and feeling unwell. He has blessed me on such moments, and I found the strength to go on. You know, its not just the spiritual strength elther, it is also because it shows me that my husband is aware of the tremendous responsibility. I have had migraine headaches at times which will not quit and doctoring doesn't he1p. But on occasions a priesthood blessing from my husband has cured me" (Case * 34 ).

Thus, Saints both male and female applaud the institution called the priesthood. Some women resent it but they are a minority.

At the same time that the young men are being prepared for the priesthood, young women are belng carefully prepared to be wives and mothers. Several organizations exist to help with the task, but it is the position of the prophet that mothers are primar 11 y responsible for the preparation of their daughters for marriage and childbearing. He admonished that "The Lord holds parents responsible for training their ch11dren in righteousness" (KImbal1, 1969, p. 258), and on the same page he tells mothers that they must take the time to sit down with their little girls of nine, ten, eleven and older, and talk about those things little girls should know. Sexual things are implied, the passage follows a section dealing with the church's position on premartial sex but the modesty of the 
passage reflects the incongruity which is encountered frequently in Momonism, on one hand, a very open presentation of role content, and encouragement of young members to make themselves attractive to members of the opposite sex, and on the other side, a stringent demand for modest decorous behavior.

Ideal Mormon youth, male or female, also belong to the Mutual Improvement Assoctation (M.I.A.). In this organization young Mormons, male and female are encouraged to develop all their talents and they become Involved in educational and recreational pursults. While the church teachings are always kept in mind the intent of this organization is not purely religlous but secular - except in so far as all aspects of personal development are interpreted as further preparations for marriage and parenthood.

While church leaders intend a more general purpose behind the M.I.A. the young people see it as a preparation (sort of flntshing school) which lmmediately preceeds marrlage, and they are constantly evaluating the young people of the opposite sex when they meet in joint ventures. Other than on college campuses M.I.A. provides the richest ground for the mating dance.

The final "rite de passage" for young Mormon men who have accepted and achleved on the 11 fe directions charted by his church is the "mission". Young Mormon men and recently women go on a two year mission to spread the faith. Ideally they go Immediately after their graduation from high school and before starting to study at college or university level or before settling to learning a life trade or profession.

Many of the young men will have identifled a sultable 
bride before they depart for the mission but marriage is out of the question until the mission has been fulfilled. Missionarles do not use their first names but refer to each other as "Elder" and their fellow Mormons as "Brother" and "Slster". While on the mission the young people have minimal contact with the family which has been their total ilfe focus and they are expected to be in the world - but not a part of 1t. For example they may be expected to assist with M. I.A. but are not allowed to dance - they are expected not to involve themselves with young women and flirting would be serlously frowned upon.

However, the young Mormon male knows with certainty that the prize is awating him and that after his mission he will certainly find a bride, some young Mormon woman who like him is longing to enter the state of Celestial Marriage and begin the family venture which with vigilance, prayer, and obedience to the church, w111 bring them in some future eternity into the Celestial Kingdom, as gods and godesses, priests and priestesses of the Heavenly Father.

While the young Mormon woman has 1 ess certainty of a husband, she too is made desirable by her dedication. Nevertheless she must walt for the pleasure of a suitable male partner.

\subsection{Role Status}

Americans outside of Mormonism (Wth the exception of those women attached to the extreme political right) are convinced that there is a gross inequality of the sexes inside the Mormon subculture. Few Mormon women would endorse this view publicly. Many not necessarily convinced, are moved to 
belleve that $1 \mathrm{t}$ is so. The classic Mormon argument to substantiate equality status surrounds the dependence of Mormon men on Mormon women in order to achieve the ultimate goal; entry to the Celestial Kingdom and a delfled nature.

Woman can only "piggy back" into the KIngdom - there is no way to do it sola, and even while men need women to get there they have the advantage that they can initiate the process. It is the male who asks the female to marry. I am not so naive as to belleve that women do not move the men to do the asking, but the final solution 1les with the men. So the woman must first walt to be asked, and then, may not get the man of her cholce. Because marriage is given such value she is likely to accept a reasonable candidate (especlally if she $1 \mathrm{~s}$ growing older) and then finds that she is utterly dependent on his willingness to live a devout and conforming life in order to assure their place and that of their children in the Celestlal KIngdom. Celestial marriages have a greater success rate than other Mormon marriages, one in sixteen couples seek a divorce, while one in 5.7 Mormon marriages contracted outside the temple do so. Even so this stands favorable comparison with American marriages in general. While Mormon women In general defend the traditional views, more and more wel1 educated Mormon women are in sllent rebellion.

In the Mormon subculture secular education has always been accorded a place of importance. Mormons belleve in the "Indestructibility of Knowledge". Knowledge is belleved to be one of the few mortal attributes which will not be lost, but be carrled with the falthful along the progressional sequence enhancing soul quality.

The majority of Mormon parents in the study believed they 
would offer equal educational opportunitles to their male and female children but in a matter of fact this did not seem to be a traditional approach. While almost all of the men in the random sample had a four year college education, few of the women did. Mormon women in general are likely to be educated about the average number of years for Amertcan women in general, but only a small minorlty finlsh college, and fewer still attain the educational average of Mormon men.

Lip service is accorded the ldea of higher education for Mormon women but, the values taught them as 1ittle girls and young women are such that the opportunity for marrlage and childbearing are likely to be given precedence. One mother who had abandoned higher education for marriage, after two years at a junior college said: "I tell my girls that $1 t^{\prime} \mathrm{s}$ all right to want to be a nurse or a teacher but nothing is as important as being a mother" (Case *21). Pointing to the fact that nursing and teaching are traditional female professtons, I asked whether it would be appropriate for a daughter to study business in preparation for work in the corporate business world, or 1aw, or maybe engfneerlng? The mother hesttated, and then went on to say,

"We11 I suppose business and law "might" be acceptable providing she was not an aggressive person, and provided she could juggle a career and being a wife and mother in the way the church teaches. However, she sald "engineering would not be encouraged."

Asked to explain further she extrapolated: "It would simpily not be in keeping with the tradition of Mormon women. There have been many great Mormon women but the1r greatness has been related to feminine pursults" (Case *21). This statement can 
be questioned in terms of history (Arrington \& Bitton, 1979).

Most Mormon women seem to accept and embrace the 1deal and some flght tenactously to extend parts of it to American womanhood in general, Mormon and not-Mormon allke. Mormons Insist that because men need women for marriage and for founding famllies; and because women need men for begetting ch1ldren, and because each depends on the other for entrance to Celestial Glory they are equally valued. Nevertheless, Mormon writings are clear, women are less than men, and there are clear proscriptions forbidding their entry to the priesthood. McConkte (1965, p. 594) writes "Women do not have the priesthood conferred upon them and are not ordained to offices therein but they are entitled to all priesthood blessings..." However, these blessings are secondhand - no woman can get them on her own.

There is a great deal of discussion of equality among Mormon women and the protesters are so loud that one is inclined to declare with Shakespeare "Me thinks thou dost protest too much!"

5.4. The Unmarried Members

The "ideal" Salnt does not remain unmarried. Arrington and Bitton (1979) state:

"Th1s understanding of sex roles has produced characteristic patterns of courtahip and marriage. ... Sometimes the Ideallsm produces problems. ... And the strong emphasis on marriage sometimes takes a toll on those who for various reasons remain single, for the difficulty of finding an accepted place in a family orlented culture may cause a loss of self-esteem." 
They go on: "In recent years the church has pald Increasing attention to the single minorlty ...but, $1 t$ continues to advocate successful marriage, partnership and stable, mutually fulfilling family experiences as the best builders of both individual and social strength." (p. 187)

and the prophet himself writes: "The gateway to the green pastures of eternal bliss is temple marriage and, righteous and abundant fam1ly 1ife" (Kimbal1, 1969, p. 242).

The displeasure of God towards those who do not fulf111 the laws of God and church are expressed by the prophet in terms, the meaning of which cannot be doubted, nor are there any 1oopholes - even the fundamental doctrine of salvation based on faith is denied the Mormon Saint. Christ's sacrifice is not 1 gnored by the church but the emphasis 1 s other than in the fundamental Christian churches. The prophet writes:

One of the most fallaclous doctrines originated by Satan and propounded by man is that man is saved alone by the grace of God. .... Church members are fortunate Indeed to have scriptures brought forth in this age which clarify this and other doctrinal questions beyond all doubt (Kimba11, 1969, p. 206-207).

one passage in the book of Mormon ftten perhaps ..to stress and inducse appreclation for this "gracious gift" (Christ's sacrifice) is particularly enlightening:

"For we labor diligently to write, to persuade our children, and also our bretheren, to belleve In Chrlst, and to be reconclled to God; for we know that it is by grace we are saved, 'after al1 we can dol"' (2 Neph1 
With this interpretation of the gospel, the leadership of the Mormon establishment stress the importance of obedience to God, and to the Interpretation of his wishes as they are transmitted through church teachings.

Speaking of obedlence to God and Implying obedience to the laws of the church he writes: "...self-control, self-mastery, can be substituted for the dominton of sin, and the slinner can move by his own agency toward God rather than under the control of Satan" (KImball, 1969). Mormons are taught that they have free agency (free wi11) but they are carefully schooled throughout life to understand that free agency must be exerclsed for the purpose of right decisions based on church teaching. An abuse of free agency wi11 condemn rather than save the individual. Each declsion faced in life must be welghed agalnst the church's teachings and each hunan incident it seems has been forseen. There exists vigorous and precise council for almost every exlgency and if it is not written, then advice, is to be sought from the local bishop, stake president and eventually from the general authorities or the prophet himself.

Trangression of the laws of God as interpreted by the church are to be treated first by kind admonition and advice; by assistance, and fellowshipping, and by vigilant care from the authorftles; but, eventual fallure to change unacceptable posttions or behavior, is treated harshly. The interpretation of the meaning of excommunication offered by the prophet himself is frightening in its severity, conjuring up a picture of desolation:

This dread action means total severance of the individual from the church. The person who is excommuntcated loses 
his membership in the church and all attendant blessings ...he is in a worse condition than he was before he joined the church. He has lost the Holy Ghost, his priesthood, his endowments, his sealings (eternal relationship to fanily members), his privileges and his claim on eternal 11fe. ...A true Latter Day Saint would far prefer to see a loved one in his bier than excommunicated from the church. If the one cut off did not have this feeling of desolatness, and barreness, and extreme 1oss, it would be evidence that he did not understand the meaning of excommunication (KImbal1, 1969, p. 329).

The compelling authorfty of these statements and the strength of the ties to Mormon family life make it clear that dissention could never be popular, and disagreement would end in disaster in terms of the individual in his/her relation to the family and community, and any behavior labelled as deviant would encure ostracism.

\subsection{Masculinity and Femininity}

Many of the Salnts spoke to the question of masculinity and femininity and the meanings of these in the subculture of Mormonism. Some of the adjectives used in describing these were: 


$\begin{array}{ll}\text { MALE } & \frac{\text { FEMALE }}{\text { soft }} \\ \text { dominant } & \text { lovely } \\ \text { strong } & \text { loving } \\ \text { powerful } & \text { maternal } \\ \text { responsible } & \text { lenient } \\ \text { hard working } & \text { caring } \\ \text { caring } & \text { a good homemaker } \\ \text { a good provider } & \end{array}$

The ideal attributes for men and women in Mormonism have ilttle to do with physical quality or so it would seem. One Saint sald:

"Masculinity and femininity are much more the way people think than a body thing. It has to do with knowing what is right for men and women to do, for a man, being responsible for a wife and children and for a woman being willing to bear children, love a husband and mother the kids proper1y" (Case*34).

Despite the fact that the church and individual Mormons put a great emphasis on spiritual and pragwatic attributes there $1 \mathrm{~s}$ another slde which is obvious to the observer. An observation note reads:

In Salt Lake City one day $I$ was visiting a family and while there the woman recelved a telephone call from her sister who had delivered her first child only the day before. The family was very excited - the new member of the family was obviously very welcome. When she got off the telephone, Sally told me, "My sister's so excited, her husband just gave her a lifetime membership for the health spa as a gift to mark the baby's birth." (I had 
met the young woman in question, she was about 21 years old and looked as if she would be very slended when not pregnant. Also, in my culture of origin it is customary to mark the birth of a first chlld (if financially possible) with a piece of jewerly, some lasting token of the occasion.) So, a 1ittle surprised I said, "Is that a customary gift?" "Oh, yes" sald Sally - "it is the big thing these days. You know we have to keep in shape for the boys, and the boys see we do."

While the "ideal" masculine and feminine characteristics stressed by men and women allke are those listed, and relate to the subcultural norm it is clear when one lives in zion, that young Mormons are very aware of the values stressed in American society at large - dress, demeanor, and the physical attributes represented by symbols such as life membership in a health spa.

5.6. What the Ideal Saint is Not

Because Mormons live in the continental U.S.A. they are affected by many of the currents of change which impinge on the lives of malnstream Americans. There is increasing evidence that those social problems facing mainstream Americans also affect the Salnts in lesser measure. Kimball (1969) cited the increasing divorce rate and the decreasing number of Temple marriages. Other soclal problems which crop up with increasing regulartty are child abuse cases and the growing numbers of youthful defections because of a cholce of a homosexual Iife style. One thing the "1deal" Saint is not, is homosexual. The Saints who took part in the study were emphatic in this regard. 
"The homosexual is wasting his potential in terms of how he is going to get back to the Heavenly Father. Those who are heterosexual are at least on the right track. I'm not against the person of the homosexual, only his sin."

Investigator: "Are you saying that your approach 18 one of morality?"

"Yes, its not the person, but the $\sin ^{\prime \prime}$ (Case*14).

And another example:

"Homosexuals have made a wrong cholce. They have used their free agency wrongly. How that comes about I don"t know. It seems to be a lack of knowing who they are, or what they are here for, I only know thelr cholces are wrong" (Male, Case 18 ).

The parents in the study, with a few exceptions said they would feel responsible for such outcoumes in their children, a point of view which mirrors the stance of the church (Turner, 1966). One mother said:

"Everyone has a trace of these things and could go either way. It depends on how you are brougt up. Homosexuality is immoral and parents are responsible." She went on to say: "Children raised in a good home where the principles are taught w11 get married and have children."

Investigator: "Without exception?"

"We11, with only a few" (Case*1).

But one father disagreed:

"I know a few people who had real good home lives in our church, the kind of homes we belleve in, but they have not gotten marrled. They're pushing forty and don't want to get married, at least it doesn't look like it, the guys fust keep passing up the chances" (Case*39). 
This man had no opinion about the eventual outcome for these people, but I learned later that one man who fit the description was his own brother. However, other people, predominately men, did have 1deas about outcomes. Several used the same phrase as the man in Case *17: "The man who doesn't marry is really in trouble." This statement prompted me to inquire about the outcomes for women who did not marry, but they it seems are in a better position. First, because they have to "wait to be asked", and therefore can exerclse less control over the situation. And second because the doctrine of plural marriage, no longer practiced openly but never eased out in terms of spiritual value - still supports the popular Idea that women who do not marry through no fault in their own, or do not have children for the same reason, w111 be married and bear children in eternity.

The researcher has just described the way the Saints think about those who remain unmarried but are in other ways in good standing in the church, tithing, doling good works and fulfilling their temple duties in the measure permitted the unmarried. But it was quite clear that persons who do not marry in Zion, particularly men who do not marry, are suspect. Since masculinity is equated with responsibility for wife, chlldren and a home, they are viewed as something slightly less, and the loss of self-esteem spoken of by Arrington and Bitton, related to bachelorhood, was evident from the words of the subfects in the study.

But, the question of status is much more serlous when one speaks of the adult who chooses to express him or herself in a same sex erotic relationship.

Some of the subjects sald, they knew nothing about 
homosexuality other than what was written in the scriptures and what has been said by the prophet. Some examples follow:

"I just belleve what our leaders teach us. If it becomes 30 widespread that innocent souls born into this world have no opportunity to become wholesome and return to the Heavenly Father in a state which will make it possible for them to become gods. He (God) w11 destroy the earth like Sodom and Gomorrah" (Male, Case *22).

and :

"It is immoral because they are not using sex in the way it should be used, to bring souls into this world."

Researcher: "Is that the only purpose for sexuality?"

"Well no, it is also permilted for showing love between husbands and wives, providing they are not preventing children" (Case*26).

The mother above was paraphrasing the prohpet:

"...one must be conscious of the need to love one's companton more than self. There w111 be no postponement of parenthood, but a destre for children as the Lord intended and whout limiting the famlly as the world does." (KImbal1, 1969, p. 250)

The church then does not countenance expressions of sexuality between anyone other than husband and wife, and then, only iff they are willing to accept the possibility of becoming parents. "All such devlations from normal, proper heterosexual relationships are not merely unnatural but wrong in the sight of God" (Kimbal1, 1969, p. 79).

The prophet goes on to denounce the relaxed severity of national laws toward homosexuality, and to declare a general degeneration of soclety, and he admonished the falthful 
saying:

"Let us emphasize that right and wrong, righteousness and sin, are not dependent on man's interpretations, conventions and attitudes. Soclal acceptance does not change the status of an act making wrong into right."

Clarifying the mainstream "liberalizing process" the prophet decrles 1 ts Influence declarling that it is "to the detriment alike, of impressionable minds, susceptible urges, and our national decency ( $p, 79)$.

This position is consistent with the historical position of the church. Leone (1979) surveyed the proceedings of Mormon eclestiastical courts in the Arizona settlements over the last hundred years. Many of the matters dealt with by the courts were in some measure related to the standards of behavior prescribed for married couples and in family life. Leone construed that, communtty boundaries were maintained by securing the unity of those inside the boundarles and firmly excluding those outside. Thus President Kimball's strong denunciation of the mores practiced by many in the mainstream identifles the fact that the Saints are to consider themselves a people apart, a people of God. Using the traditional strategy of "them" and "us", the prophet clarifies the church's position on homosexuallty.

\subsection{Summary}

There extsts in the Mormon subculture an ideal personality. This personal profile arises out of the bellef system. In order to approach the ideal, the Salnt must marry and found a family. Because marriage and famlly are part of the construct of religion in this subculture, single persons 
are relatively less esteemed. No expressions of sexuality are permitted outside of marriage. Sanctions are executed against sinners and severe sanctions are carried out against unrepentant homosexuals. They may be excommunicated from the church.

Thus, the components of the theory of gender identity in Mormonism discussed this far, find their origin in the religion of the Latter Day Saints, and are expressed in terms of heterosexual marriage, family and childrearing. Out of these elements there emerges on "Ideal" Profile of the Saints, an Ideal which according to the evidence in the study, most Saints try to emulate. 


\section{CHAPTER 6}

\section{FOLK BELIEFS IN ZION}

Careful scruting of the elements which together create the construct, gender Identity in the Mormon subculture gives rise to the impression that most of the devoted members of the church do strive after the ideal. They also believe that the pronouncements of the General Authorities are directions from God and result from divine revelation.

As the data was sifted, sorted, and constantly compared It became evident that there were a great many belief statements which did not exactly mirror the church"s teaching. Two classifications arose out of this body of data, and the category content sorted itself into a major sub-category of folk beliefs. These folk bellefs had an origin 1 n the church teaching on tradition, and could be readily identifled as expressions of 1 t. And, a second lesser sub-category which expressed beliefs or ideas which were clearly antithetical to the church's position.

This second sub-category is important in the eyes of the researcher because the statements came, not from disenfranchised or disfellowshipped Mormons, not even from relatively lukewarm members of the falth, but instead, from devoted practicing Saints in good standing with the church.

Illustrating this body of data the researcher presents the data which is concurrent with the teachings of the church first followed by representative segments of the 1d1osyncratic data. In order to locate thls content in the total data set, and as a point of clarification the researcher relterates: 
almost $90 \%$ of the particlpants in the study expressed the church's views on marriage, family, childrearing practices and the methods of transmitting masculine and feminine roles from generation to generation.

The 1diosyncratic or antithetical statements all relate to 1deas about childrearing, and the churches position on homosexuality, and sanctions agalnst homosexuality.

One father expressing thought consonant with the church's view, sald in his own words:

"Marriage accomodates the challenges in 11fe which make you a better person."

Researcher: "Are those challenges not avallable to the unmarried?"

Father: "No! I don't personally believe they are. Marriage is a 'good package deal' if you want to achieve what most of us do."

Explaining further he said: "Children offer a valuable trade. In caring for them I learn a lot, about them, and often about myself. I want them to be proud of me and admire me, and so I work very hard at being the best I can be, as well as trylng to get as close as I can to the Ideal the church holds up before me"t (Case *3).

The following was taken from an observational note:

When I left the home of the P.'s this evening I felt quite moved. They are not very well off. At least $1 t$ didn't look that way, but $\mathrm{Mr}$. P. was such a gentle man; with his wife, towards me, and with the little boy who stubbed his toe and crled.

HIs wife sat back and admired him while he talked to me. While Mr. P. conforted the 1ittle boy Mrs. P. talked 
about her marriage. "I can't lmagine life without marrlage, we are such good friends my husband and me. We help each other to grow better and we share the joyrs and the disappointments. We lost a baby two years ago. That was very sad but we helped each other over the loss." I left their home feeling that I had caught a glimpse of the ideal. (Observational Note *21).

Many couples sald things in their own way whlch were obvilously related to their bellef in the church. For example: "Life is richer where there are children" (Case*1), and "The person without a family can have religion but he is still lost in a sense. You are only a third alive when you are alone, two thirds when you have a wife, and whole when you have children" (Case *5). Another woman sald: "Nothing can compensate for fallure in the home", then went on to say, "Families without religion fall apart more eas1ly" (Case *44).

The following again comes from an observational note:

I learned that the statement, "Nothing can compensate for fallure in the home" - is a famous saylng in the Mormon community. Several people had used the same words so I questioned Bishop $C$. about $1 t$, and he said that those words were originally sald by a general authority, and have become traditional. (Observational Note * 37).

Many Mormons respond to questions in ways that seem stereotypic. The statement below was made by a man from $M_{0}$ and is an example:

"Families that do not adhere to a religlous view cannot achieve the same kind of happiness in famlly life. It is not possible to achieve a happy and successful life without religlon" (Case*32). 
other statements had some relationship to the church"s position but were frased highly individualistic, for example: "Men and women think differently" (Case *10). When asked to elaborate the lady could not and I percelved some undercurrent between the parents which made my question uncomfortable, either that, or 1 was another stereotypic statement she had not thought about. I did not embarass her but went on.

A few people belleved that one could have a good and satisfying 11fe outside of the Mormon faith, an 1dea which is foreign to devout Mormons: "It is possible for people to have a good family 11fe whthout religion, but what I think is that they have a phllosophy, and practice right princlples without knowling 1t" (Case *7), and another Salnt said: "A Iife without religion, won't be the best kind of life but it can be satisfying nevertheless." A few people also expressed the 1dea the chlldren could be dispensed with: "A 11fe without children has other compensations" (Case *34), and another said: "Well without children you can have more of the material pleasures of 11fe. One of my work buddles just got back from Hawail - he can afford trips because he has no kids" (Case *15). These are very unusual viewpoints. Children are valued, loved and destred and because of the doctrines of pre-existance and eternal progression, children are usually desired.

Talking of "free agency" some parents pointed out that they had made cholces on behalf of their children which were not generally popular among church members.

"We let our 1ittle boys play with dolls. We think that allowing them to develop some tender feelings will make them better fathers one day."

The father went on to say: 
"Some of our friends disagree but they are our children and our responsibility" (Case *15).

Another couple talked of thelr daughter's interest in horses, and her desire to drive a tractor, and the mother sald: "I wh she were more feminine but I respect her right to choose her pleasures. I don"t blame her for enjoying horses" (Case *22). Although most parents seemed to deal with children's needs on a one to one basis, occaslonally it was clear that overpowering aspects of religlous bellef made that impossible. One father explained:

"My daughter loves to play basketball and other sports and I allow her to play for pleasure, but, we have had some grief because she wants to play competatively agalnst men, and I will not permit that."

Pressed for more information the father added:

"I think it is all right for women to exerclse in order to stay slim and healthy, but not to compete with men. Feminine women don't do that kind of thing, the church frowns on $1 t$ and we do not permit $1 t^{\prime \prime}$ (Case *26).

Another observational note was made $(0 . N . * 54)$, during the conversation between this father and the investigator the girl's mother sat looking uncomfortable and embarassed. At one point she made eye contact with me and then looked up. I think she was implying, "What can I do." I did not press for more information because the atmosphere felt potentially explosive. But, the mother concluded the subject matter by shrugging her shoulders, and saying as she stared down at her hands, "She (daughter) is a very good playerl" (Case *26).

There was occasional evidence that devotion to the church Influenced people in ways that $I$ as a health professlonal 
1nterpreted as dangerous, and unhealthy. One plece of evidence is in the following entry in the ethnographic diaries: Tonight I went to the home of family in $M$. The parents and a seven year old girl were scheduled as subjects in the study. The mother met me at the door accompanied by a 11ttle boy. He was about four I'd say. He was beautiful, sweet faced, with blond curls and he was wearing a sparkly necklace around his neck, which he rushed to show me. When his father arrived home a few minutes later he firmly Insisted that the little boy remove the necklace. The child looked sad!

After we had completed the first parts of the intervilew they started to talk about the 1ittle boy. I reallzed afterwards that they might have refused to be subjects if they had known earller about the context. But they were obviously relleved to talk to me. They are very perturbed by the 1ittle boy's behavior - especlally the father. The 1ittle boy they say "wants to be a girl!"

He came into the room after a whlle and asked if he could play wh the dolls I use for the child measurement tasks. As he examined the 11ttle boy doll he sald, "I want to be a girl, but daddy won't let me." I sent him off with his sister to play in the next room with the do11s.

After he left the parents showed their concern open1y. The father sald, "He keeps saying 1t, at first I tought It was a game but 1 ts all the time." The mother explained that at nursery school that morning the child has put on an apron and was playing with cooking utensils when the other little boys began to tease him saying "You are a 
g1r1." The mother sald he looked confused so she suggested he take the apron off. He did so, but on the way home in the car he sald to his mother, "I wanted to keep the apron on, I want to be a girl."

The father 1s very angry - Insists that the child w111 do only masculine things. The mother is over protective, she repeated several times, "He's so little."

They asked me if I thought he'd grow out of it. I sald that he very well might - but that $I^{\prime} \mathrm{d}$ advise them to have a good physical check done to make sure that the child's gender has been correctly assigned. There were appalled at the thought that there could be a mistake. I tried to reassure them reiterating that a physical check was the starting place to deal with their concern. I suggested that they talk with their physiclan and seek speclalist care - I even talked about John Money, at Johns Hopkins. *)

I left feeling very sad - the father kept protesting about the way the church advises the development of masculinity. I hope and pray they will get specialist assistance but fear they will not. (Entry*112)

The greatest deviation of thought from the universal nom among the Saints was encountered in statements which related to "parental responsibility for their children"s subsequent behavior in adulthood" and, "questions surrounding the subject of homosexuality".

*) As a pediatric surgeon/sexologist, Dr. John Money, 1 s an acknowledged spectalist in the fleld of gender assessment. 
It was evident that many of the adult subjects had considered and discussed these subjects in other contexts before the interviews. These two classifications of folk bellefs will be treated In one body.

Some of the parents felt totally responsible for thell children's subsequent adult behavior, a stance, which is consistant with the church's position. President Kimball (1969) lays the responsibility falrly and squarely on parental shoulders saying that children who stray or err, were not brought up in the right home atmosphere. However parents, even those with young children did not always agree with this point of view. A father said on this subject:

"It would cause me a lot of heartache if they did not turn out the way I expected but, you cannot stay wh them every moment of your 11fe. You do the best you can, then pray" (Case *26),

and another father sald:

"I don't think we would ever be free of the "feeling" of responsibility but $I$ am not sure that's appropriate. After all there 18 an ultimate point beyond which everyone must carry his or her own rock, nevertheless as a concerned father I would continue to worry and to try to help that child to regain the balance he or she needs in order to be happy." and the mother in this family added, "After I had done all that I could, I would try to remember that after all the child has free agency" (Case *27).

One young father who was also a mental health professional said:

"In my experience children who devlate serlously from the 
Mormon Ideal are rejected. Homosexuality often brings utter rejection - I don't agree with that point of view, but that"s what happens most of the time in my experlence" (Case *33),

and a father who had been a bishop sald:

"Homosexuality is wrong, it is immoral."

Researcher: "How would you deal with a child who chose a homosexual lifestyle?"

Father: "I would never whthdraw my love from the child, I would try to behave like the father of the Prodigal Son in the Gospel."

Researcher: "But, the Prodigal Son came back, repentant. What if the child persisted?"

Father: "I"d do everything I could, get church, and professional counseling but I'd never stop loving him." Mother: "You can't stop loving a child because he does something wrong. You must go on loving him" (Case $* 26$ ).

The tenacious resolve to love children no matter what, is related to the great value the Saints place on the concept of family, and their belief in the insoluble bonds created through temple marriage.

Much of the body of ldlosyncratic data related to the subject of homosexuality. Sometimes the couples had encountered homosexuality in a relative or friend. Most of these were unwillng or unable to resolve the question on purely moral grounds. One woman who sald that her faith had never been challenged - she had lived such a sheltered life, responded about homosexuality in this way: "It seems complex. I am taught that it is a moral question, but I'm not sure, but I think we are soon going to understand more about it than we 
do now:" This lady's statement reflects the religlous bellef in contemporary revelation. "God will clarify for his people." Her husband continued on the subject saying: "Each of us is responsible for our cholces, we have free agency and we can choose, but homosexuality? I wonder a lot about it, maybe its a genetic thing" (Case *10).

Another couple sald: Mother : "I don"t know if teaching and example is enough. You can teach them (children) but If they have a different feeling inside of them they" 11 be different." Father continued: "Its gotta come from both sources, what the person feels about themselves, and how they are reared" (Case *39)

One couple shared their personal experience and their opinions about the causes of homosexuality:

Mother: "We have a situation in our own family of a niece who married a man who was homosexual. He has done nothing to try to change himself since he was reckoned with by the church. I think there was a poor father-son relationship, but he had four brothers and sisters, and they are not homosexual. They were all brought up together.

I thlnk people get off into that kind of program to get back at people - to hurt people, they are not really homosexual they simply carry the label for social purposes, to cause pain, they fust dabble with $1 . t$."

Researcher: "Do you have any thoughts about why this one member of the family 1 s homosexual and not the others?" Father: "We11 I think it has to do with interpersonal relationships between parents and children. A believe the rellgous atmosphere in the home is the same for all the 
children whlle the relationship between each parent and each child is unique" (Case *10).

This couple has thought and talked a lot about the question of homosexuality and neither mentioned "morality".

One man, on the subject of homosexuallty, responded in a way that was truly idiosyncratic, saying:

"I don't believe its a question of morality. That's far too simple! I agree we don't know what $1 \mathrm{t}$ is, but people who love their families and their friends won't transgress the laws like this unless it's something strong that moves them. I wish we knew what it $1 \mathrm{~s}^{\prime \prime}$ (Case *37),

and another said something quite similar:

"Whether the homosexual is a male or female its just as bad if you see it as a moral transgression. However, I am not at all sure that it is, we really don't know at all. Sclence hasn't come up with an answer yet" (Case*7). Several couples talked in ways that related to the last example, but, linking homosexuality to physiologlcal factors: "I think there is something born inside of them and the way they are brought up does the rest (Female, Case *9), and another woman sald: "Things like genes are important. I don't know that the way you rear your chlldren can cancel that out" (Case *44).

A few people sald positive things about homosexwals difficult to reconcile with the church"s ostracizing position. "I think homosexuals are equally valuable as professtonals, good teachers, and so on. I think they are of the spirt of worth - they just made wrong cholces" (Case*2).

One couple talked of a young friend, a homosexual trying to 
"overcone" hils homosexual feelings saylng: "He finds our fam1ly structure unbearable and that has always been the case. We belleve (this couple) that seeds of rebellion in our personalities may cause us to develop differently" (Case *10).

The statement above relates to the church's position but is not the same. One woman has a totally original idea. She said, "People get poisoned by the food they eat. They get toxic blood and 1 t affects their thinking. I'm not saying 1 ts the only cause of homsexuality but I think 1 t has something to do with it" (Case*18).

Finally, one man, who seemed very thoughtful, and kind sald:

"The only reason I believe that a homosexual would live that way $1 \mathrm{~s}$ because they are unhappy the other way."

Researcher: "Are you saying that there tight be a homosexual personality, persons for whom homosexuality is a natural form of loving expression?"

"I guess I am, maybe there are even righteous homosexuals. I don't know, I am not a judge."

Many of the subjects in the study confirmed their belief in the church's position that the only "natural" mode of sexual expression is heterosexual, and that God's people can be happy only in that fashion.

Summary

It is clear from these examples and others in the data that many Mormons, happily married and engaged in raising famllies are not comfortable with the church's position on homosexuality.

While most Mormons accept without question the view of 
the General Authority, others are perturbed by its severity. Bishops assured me that there are increasing numbers of homosexuals among Mormons. One subject in the study told of "numbers" of young Mormon missionaries becoming lnvolved in homosexual "relations", and several couples in the study recounted episodes which involved their own familles. Personal experience has created a need for them to explain the phenomena in a way which does not violate the "family". Family is the central cognitive structure in the belief system tying together, with marriage bellefs to form rellglon. One subject said that in Mormonism, marriage and family are religion.

Mormons have many bellefs about aspects of gender identity which are not directly attributable to church doctrine. Nevertheless the majority of these are congruent with the churches teaching though a smaller number are not. 
CHAPTER 7

SOCIAL RESPONSIB ILITIES

Contemporary Mormons are serlously committed to the American protestant ethic as defined by Weber (1958). He professed a relationship between Calvinistic values which glorify work and ascetic lifestyle on one hand, and the growth of capltalism on the other. The endorsement of the Protestant principle described above directed many thinkers away from the Aristotelian ideal of equality toward the Calvinistic spirit of equity, or the theory of accumulation of rewards proportionate to effort invested. In a discussion of this shift Tillich (1971) stated "The dissolution of the antithesis of the sacred and the profane represents the profoundest aspect of the Protestant principle" (p. 65). This glorification of work as an end in itself was identified by Weber as the foundation which sustains the capitalistic system.

Mormons glorify work, a fact expressed by them in words and in symbols. "The term Desert is widely used by Mormons as are the symbols of bee and beehtve to denote industry, hard work and perseverance" (Mirels and Garrett, 1971). The church malntalns its own soclal welfare organization and is proud of Its ability to sustain members who find themselves in economic difflculties. This distribution methods of the welfare system relnforce the Weberian position on capltallsm. "He who does not work, shall not eat", and the idealism of an equity ethic. The Church of the Latter Day Saints maintains that people need to work and that it is more important for them to become 
self-sustaining than it is te receive charlty. Thus every person who receives assistance from the relfef soclety or Institute is expected to work for the church and community and/or make themselves avallable to learn self-sustaining life skills. Mo1 (1972) has identifled the strong social welfare program of the Mormon church as a key factor to explain the remarkable growth of Mormonism in North America.

Subjects in the study percelved their social responsibilities in two mutually inclusive categorles. Those responsibilities arising in their group nembership encompassed by those which related to their American citizenship. "Religion may serve as a significant component of a wider cultural tradition" (Miles and Garrett, 1971). This plurality has been highlighted by O'Dea (1955) who called the Book of Mormon, "an American document". It is also embodied in the early viston of Joseph Snlth who belleved and taught that the true gospel was restored on the American continent.

Early Mormon settlements in Utah were communal systems more closely alligned with the 1deals of equality than equity, and accordingly more democratic than conservative. Greenberg (1978) has drawn attention to the phenomenon that equity as ethic is preferred by males and is frequently predominant in paternalistic cultures. Also in this respect the subculture of Mormonism can be caracterized as a strong paternalistic and authoritarian system.

Modern Mormonism still reflects some of the elements of the ear1y 19 th century frontier soclety. The ecological context in which Mormonism also stil exists. Many American members of the church continue to live in Utah, and the soclal experience of early times is recreated in contemporary group 
cohesivenes. Turner has drawn attention to the fact that in such clrcumstances symbols remain extraordinarly viable. Oral and written accounts contribute to reinforce history on a daily basis. But, $a$ s well as historical influences, contemporary social, economic and political positions, express the theological and 1deological set of the group. Many Mormons become involved in political $11 f e$ at state and national levels, a fact conflrmed by Dolg in (1979).

Utah State Covernment is reported to be $90-95 \%$ Mormon though the state is peopled by $70 \%$ Mormons and $30 \%$ non-Mormons, (Jonas, 1961). Rampton - three times state governor of Utah - has sald that the overrepresentation can be explained by the fact that Mormons vote, and they vote for Mormons. Thus, Mormons take their social responsibilities as state citizens serlously, but the fact that they vote for Momons reflects their plural comftment. Many representatives are not simply church members but church leaders, as a result, the Utah legislature can be sald to be controlled by Mormon church officials whose consclence is dictated by church teaching. Mormons acknowledge their church"s educational efforts in secular as we 11 as religlous matters, and as a result, theologlcal and 1 deological positions direct state government decisions.

The soclal traditions of famlly and marriage subsume those of masculinity and femininity in Mormon thought. This w111 say that the average Mormon belleves he/she can successfully meet their social obligations to subculture and culture only when these responslbilities are executed in terms of behaviors which are consistent with the Mormon concept of gender Identity as $1 t$ is expressed in gender role. The Saints 
have served generously in the armed forces, underlining thelr willingness to offer their manhood to protect the American dream.

When the subjects in the study spoke of society, they usually meant the Mormon community of which they are a part or/and, the state of Utah. However, they are not disconnected from the rest of the continental Unfted states, or American society in general.

Mormon parents define their obligation of role transference to their chlldren as a "soclal obligation". "Parents responsibility to each other and the quality of that relationship is a social responsibility. It helps children to relate to people of the opposite sex later on" (Case*27), and they also see a social obligation to maintain decorum in their marital relations. "I think parents who are stepping out on each other, and whether they get along, does things to the kids. They have a social obligation to the kids to keep the family together" (Case *65). This statement demonstrates the strong sense of responsibility members of Mormon families share. Parents who "step out" cause shame and blame to fall on their kin.

One couple who sald that they have been Involved in working with young homosexuals inside their community related: "We have a soclal obligation to help these people. In our Bishopbric we receive more and more instructions from the General Authorities about how to work with them so you see the church is aware of the Increasing numbers" (Case *34).

The Saints see the social responsibilities of family, 
communfty, state and country in positive terms. One father who was also a blshop explained:

"In order to learn how to be a God you must have a unit to govern, on which to learn and that is the family. You must learn to control and manage that first."

Researcher: "What does the church teach you wi11 you create as gods?"

Mother: "We w111 create other worlds, larger social units based on our own progeny. And, they will also procreate and the world w11 grow larger."

Father: "We can do all of this if we follow the churches teachings because we have the life of God in us."

Researcher: "Does that mean that social responstbilities in this world are welcomed as learning experiences?"

Father: "Yes! Some members of our church have offices in local and state and even national government - we see all of those responsibilities as learning opportunities."

George Romney one time governor of the State of Michigan, national1y recognized as a Mormon, expresses the same idea: "We belleve when we are in the service of our fellow man, we are in the service of the Creator" (Turner, 1969, p. 304).

The practice of homosexuality is interpreted by some Salnts as antisocial behavior. "Homosexuality is a sad thing, it causes hardship and sorrow and remorse. It brings grief to families and that is 1rresponsible, and antisocla1" (Case *18).

The Salnt who views the question of homosexuality in a broader soclal frame is exemplified here: "Social contributions can be made by homosexuals", (Case *14) and again by the woman who sald: 
"Homosexuals meet some social obligations. They contribute to mankind and make positive literary statements; she went on to say, "But their sexual preferences are antisocial in our frame of reference" (Case *31).

Here she is speaking of soctety in terms of the Momon subculture. One man sald, "There is no soclal value in homosexuality" (Case *23). When asked to clarify he sald: "The world would end if we were al1 homosexual." The researcher agreed, but pointed out the heterosexuality of soclety at large, asking him whether the small number of homosexuals could create such havoc. The subject repeated: "There is no social value in homosexuality" (Case *23). This person is expressing ideas about society at large - which reflect the position of the General Authorities of the church.

Legal and political sanctions against homosexuals are strict in the State of Utah. Galliher and Basilick (1979:290) theorize: "In a state 1ike Utah, as in any theocracy, the linkage between morality and leglslation is easy to trace compared to that in areas which are morally and polltically heterogeneous." There are soctal demands for conformity to norms of role performance, and punishment is meted out to those who fall to conform. There are also avallable social rewards for conformity. Opportunities are avaliable for Individuals to gain satisfaction of subjectively experienced needs, by following the accepted path ways. All societies malntain order by a system of demands and oportunities, some are heavy on demands, and some on opportunities. There 18 little question that same personalities are more malleable than others, finding it easier to conform to norms or follow 
the directed paths.

Soclal responsibility both internal (within the subculture of Mormonlsm) and external (in Amerlican soctety at large) 1 s rooted in the religious bellef system. Social roles are defined and executed in Saintly terms.

Soclal responsibilities in the Mormon subculture are congruent with the most conservative of American values, reinforcing the protestant work ethic, supporting and sustaining capitalism. Social responses expressed by and observed among Mormons reflect church teaching. Public or social functions are carried out by devout Mormons as if they were in the shadow of Temple square.

The descriptive material contained in the previous chapters describes the phenomenological field encompassing the cognitive construct of gender identity in the subculture of Mormonism. Behavior 111ustrates thought, therefore, the behavior prescribed and destred by the church, has been Identified wherever it can 111 uminate the data.

Even as the data is described the theory continues to present 1tgelf in an increasingly clear construction. Earlier in the analytic process it was belleved by the researcher that the body of data labelled "Idiosyncratic" lay outside the major construct. That will say, it appeared to be secular in origin, but this can be doubted on good reasons (see chapter 8).

Religion or the religious belief system in Mormonism maintains its traditional emphasis on "fam $11 y^{\prime \prime}$. McConkie, a respected theologian bases his definition of family on scripture (the Bible) and the Doctrine and Covenants of the 
Church of Jesus Chrlst of Latter Day Salnts. He explains that the family is the "primary" unit of Latter Day Saint's belief. Through the medium of Celestial or Temple marriage Mormon young people create a kinship affiliation which they believe is Indestructible. "Sealings" can be disolved only by the prophet or President of the church, and this for very serlous reasons (McConkie, 1966, p. 111).

Marriage and family together, form the training ground for future Salnts. The members of the church believe that souls who are their spirit $\mathrm{kIn}$ are awalting release from a pre-existence. Without a mortal existence none of these souls can embark on the trajectory of eternal progression, which w111 permit them to reach glory, and eventually, (dependent on devotion, throughout life, and other conditions) entry into the coveted Celestial Kingdom, or the presence of God.

The childrearing process which is family centered has as its main intent the instruction and direction of children in ways which will assist them in this spiritual task. Education for that end is both spiritual and secular. No aspect of this child education task is left to chance. The central administration of the church provides educational direction in the form of annual publications, prepared as guides for the educational venture. Sunbeam manual (pre-schoo1, secular focus); primary manuals (secular and relfglous content); materials for boy scouts and girl scouts; for the Mutual Improvement Soclety; and for Family Home Evening, and countless other accasions.

Because family is the primary unit of the church, there is a studied, concentrated emphasis in home and church, (as we 11 as most schools in Utah), on the development of 
traditional gender roles. There is evidence of differential sociallzation of male and female children by parents, an approach which is supported by tradition. Transference of Information about traditional roles in the subculture is relnforced by collectively organized preparation, for the rituals, and rites of passage, which stabilize outcones. They emphas1ze important landmarks such as baptism by immersion, and the degrees and order which lead eventually to admission of the priesthood for males. The step by step preparation is essentlal for all who choose to be married in the Temple. loung women are also prepared for their roles as wives and mothers, by their parents, (particularly mothers) and female relatives; but also by the organization. The social organization defines the educational process as a social responsibllity whlch accrues to each practicing Mormon, a position which theorists have observed in other Western socleties hich are pluralistic in orientation. Garbarino and Bronfenbrenner (1976:102) "...peer pressures strenghten any tendency toward rejection of the conventional moral response." Singleness 18 not considered blessed among the saints. Every man and woman is expected to prepare for marriage and search for a suitable partner. Those who never marry are relatively less-esteemed. Many of those who are not Invited to marriage, or who secretly avoid 1t, engage in church and community service attempting to make up the deficit with good works.

There is an "Idea1" profile of the Saint. Most Mormons aspire to this ideal. Because the family is the basic unit of bellef and central to success in Latter Day Saint terms, expression of sexuality outside of marriage is forbidden. 
Homosexuality is called un-masculine, because masculinity is equated with responsibllity for wife and famliy. The church executes severe spiritual sanctions agalnst unrepentant sinners in general and practicing homosexulals in particular.

Social responsibilities fall into two categories - those which are a part of the internal life of the subculture and those which relate to the greater society; the United States of America. Social roles in subculture and culture, reflect the characteristics of behavior considered approprlate for males and females as prescribed by the belief system, and American mainstream values of work ethic and capitalism.

The category of data, Folk Bellefs, 11lustrated that the attitudes and bellefs of the parents in the study regarding traditional transmission of identity role content was of an orthodox nature. A majority of Salnts accept the proscriptlve attitude of the church toward homosexuality and homosexuals. They belleve that the homosexual deprives $\mathrm{h} / \mathrm{m} / \mathrm{herself}$ of any chance of returning to the presence of the Heavenly Father, by foregoing marriage and squandering the potential for parenthood. Marriage and family are rigid prerequisites for admittance to the Celestial Kingdom.

However, not all Mormons are comfortable with the apparently immovable position of the General Authorities regarding homosexuality. Those who have family members or friends who are homosexuals and those who have worked efther professionally or in church context with them, are less stringent in their views. Many of these are overwhelmed by the severfty of the spirftual sanctions pronounced on homosexuals.

Since a 11 of the participants in the study were recognized by their church as "members in good standing" and 
since they see themselves as devoted Mormons, it was necessary to return to the data in order to present conclusions. 
CHAPTER 8

\author{
FINDINGS
}

\title{
8.1. Demonstrating Association in the Data
}

The general content of the data in this study supports Turner's observation that the religion of the Latter Day Saints is a "way of 1ife". The church offers spiritual guidance and secular education. It is a complex religion in modern times and it is possible for the individual members to find many of the daily solutions which life demands within its framework. It is not the purpose of this study to consider the validity of those solutions.

The primary purpose of the study is to describe the phenomenological field which influences the cognitive structure of gender identity as it is prescribed and expressed In gender roles in the subculture. If as Money and Erhardt (1972) suggest, gender 1dentity is the private understanding of gender role; and gender role the public expression of gender identity, an association will of necessity exist between the two. Adult expression of gender role, together with bellefs and attitudes about gender, will become a part of the dialectical process influencing emergent gender comprehensiton in the developlng child.

It is clear from analysis of this body of data that, cognition surrounding; and behaviors expressing; gender ldentity, and gender role in the subculture of Mormonism, are intimately related to, and express, the religlous bellefs and teachings of the church.

Five of the six concepts which emerged from the data can 
be related to the core concept "Religion", In direct and significant association.

Concepts Religlous Bellefs, Child Rearing and Mormon Family are in direct relationship with the core construct which is religion. Concept Ideal Profile of the Saints, a construct whose properties emerge from the first three categorles, is also deeply embedded in the core concept religion. The construct Social Responsibilitles 11lustrates in-group and civic responsibilities as they are percelved by the saint and described by the chruch. This concept also belongs in direct relationship with the core construct. The slxth category, Folk Beliefs, has to be subdivided into two sections, a) Traditional Beliefs (these are usually indirect or secular in nature but are congruent with the church's teaching and rooted in the belfef system) and b) the items of an idlosyncratic or non-traditional nature. This category is in opposition to the dogmatic religous bellefs of Mormonism but demonstrates a relationship to the construct of family, which is described as the "primary unit of belief" in the Church of Jesus Christ of Latter Day Saints. The relationships between the concepts, the constructs, and their properties, is In scheme 1.

\subsection{Discusstion}

The purpose of this study has been to examine, describe, classify, analyze and synthesize the cognitive constructs and soctal referents of gender identity and gender role in the subculture of Mormonism, and to demonstrate the findings of multiple measures in terms of construct validity.

The qualitative findings, with few exceptions, 


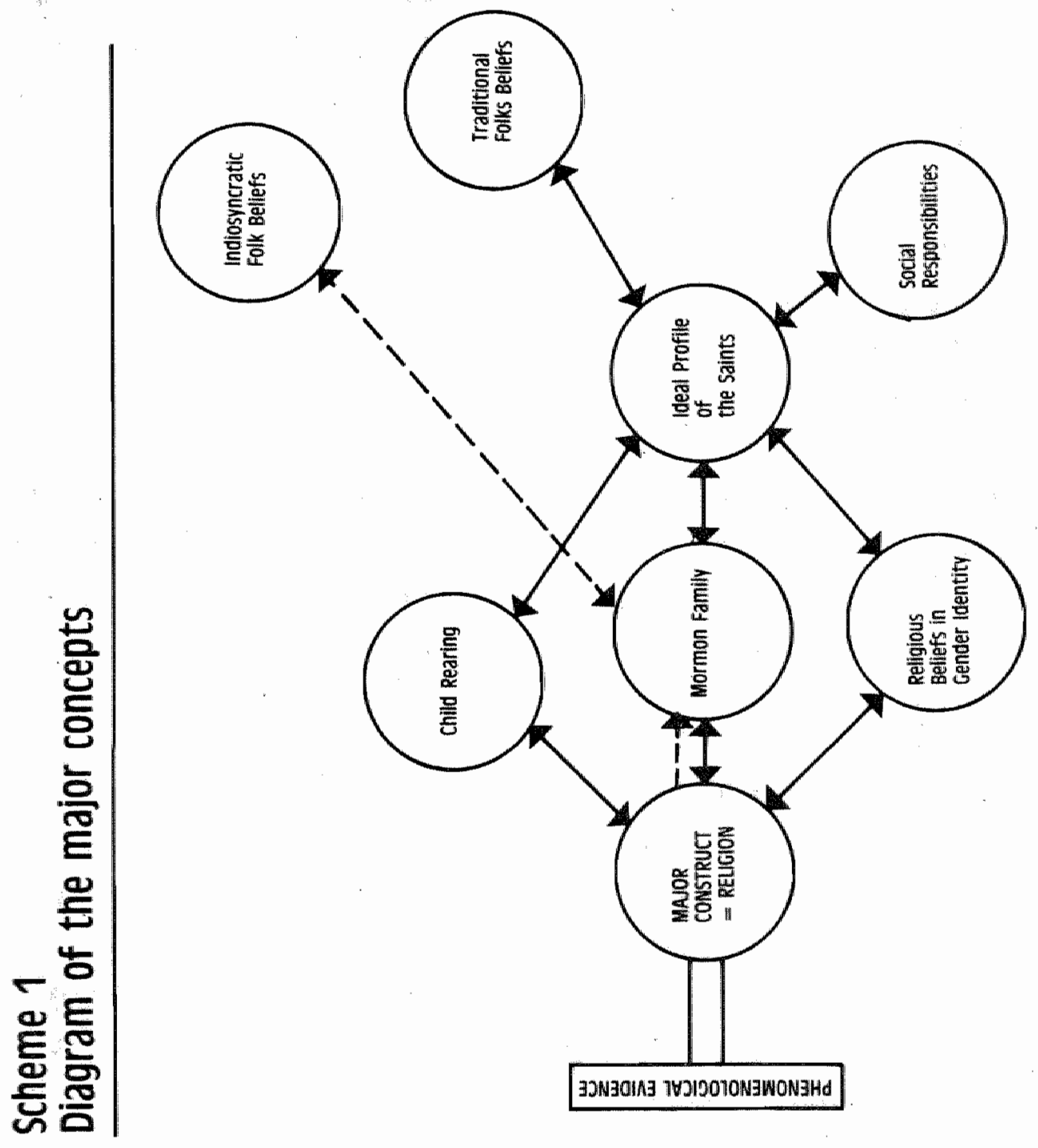


demonstrate that the 94 parents in the study accept the authoritariap views of the church on those aspects of $11 \mathrm{fe}$ which describe and encompass the construct of gender identity and 1 ts expression in gender role. This position is consistent w th the history of Mormon groups "...w1thout question Mormons have displayed a strong spirit of group consclousness" (Arrington \& Bitton, 1979, p. 309). In the opinion of Sorenson (1974) a contemporary anthropologist, Mormons in the eighties are not 11kely to change. He suggests that they tend to obey authority, accepting the statements of church authorities even when they are incompatible with their own views. He suggests that Mormons have a predilection for order and predictability. In ldentifylng this desire for presclence displayed by Mormon Individuals Sorenson may have focused on one of the major variables explaining the acceptance of group norms on a wide scale which lllustrates a categorical shift away from the operational definitions of the religion as presented by Joseph Smith. "Joseph Smith and his peers glimpsed the createdness of truth, its capacity to change and its locus in the individual" (Leone, 1979, p. 221). Th1s shift is not an limediate modern innovation but has become increasingly evident over the last sixty years.

Turner (1966, p. 53) is of the opinion that over time, "It has become the most serlous of religlous crimes to question the Integrity or good faith or power of the General Authorities." The Influence of this authority on the Individual takes many forms. One of the most invasive, is the demand for a declaration of faithfulness to the authorities as well as the rules and doctrines of the church which is required of all Mormons seeking permission to visit the Temple 
for the purpose of executing rituals.

Only those Saints willing to swear that they are: morally clean and worthy, have pald their tithes or are offlcially exempted therefrom, maintain the prohibitions concerning stimulating beverages and alcohol, wear the ritaal garment at a11 times, fulfill thelr church duties, and remain separate from persons or groups who run counter to the church"s teachings are consldered for "Temple recommends". Distancing oneself from the church, by falling to meet the standards increases the necessity for the individual to solve life's crises independently. While the social organization of the church underilnes the development of personal autonomy it is not a real autonomy but one which askes that members make personal decisions within the framework of family and ward community, inside the framework of religion, consclously balancing the importance of individual freedom with his or her social obligations to the collectivity. Achleving true autonomy 18 made difficult for the individual by the very fact that he/she has been socialized in an extraordinarily supportive environment since birth.

Those authors who have written extensively about Mormons are agreed about the goodness of Mormons in general and the $1 r$ sincere efforts to achleve the Saintly "Ideal", they are anong others, Arrington and B1tton, Dolg1n, Leone, O'Dea and Turner. The findings in this study sustain the impression that Mormons strive to follow the church daily.

As Mormons work at saintliness they look to the prophet for Inspliation and direction, Turner writes, "...the President is still completely powerful in religlous matters" (1966, p. 52), and it is he, speaking clearly for the church 
who Identifles the sequence of life events which the falthful Salnt must atrive to create, if they wish an assurance of eternal good (Kimbal1, 1969). The sequence is traditional and orthodox, and because faithful Mormons belleve that he speaks for God they strive to obey the letter of the law.

Sometimes the revelation disseminated from the Upper Room offers comfort to the Saints. This was the case with a letter written in June 1978, announcing, that in the future all worthy malles of whatever race or color, would be admitted to the priesthood. The exclusion of falthful black males from the privileges of this order had been a source of severe embarasament to some of the fatthful for a number of years. It made them particularly susceptible to criticism in the late $1960^{\prime} \mathrm{s}$ and the early seventies. Leone (1979, p. 224) writes of this situation that it made ...many Mormons secretly suspictous of themselves for having to condone such a soclally unacceptable doctrine." The prophets credibility as a revelator was sustained by the pronouncement. Fafthful Mormons belfeved as the prophet declared that God had heard his request for guldance in the matter. Mormons felt that the Heavenly Father had handed down an answer that increased their credibility as American citizens in step with the postive changes in American aclety.

Even though the Mormon church is organizationally stable, and patrlarchall in nature it has built into its structure the potentlal for change of any kind. The dactrine of contemporary revelation acts as a trigger mechanism which could support the "creative Innovation" which Bellah (1972) incorporates in his model of religlous evolution. Flexibility according to Bellah is essential to the survival of modern religlons. Talking of 
orthodoxy he goes on to say, "...every fixed position has become open to question in the task of making sense out of man and his situation." President Kimball (1969) and the General Authorities seem Iittle concerned with "man and his situation" but more concerned about how man can be made to conform himself/herself to structured definitions of the situation delivered by the central authority. Bellah goes on:

I expect traditional religlous symbolism to be maintained and developed in new directions, but with the growing awareness that it is symbollsm and that man is in the last analysis responsible for the choice of his symbollsm (p. 49).

Concluding their historical notes on Mormonism, Arrington and Bitton (1979, p. 335) remark that people who criticize the church for its "program-oriented institutional approach" have falled to notice the tradition of continuous revelation which permits the reformation of policies and bellefs in order that they retain their vibrant form. But they also identify the fact that only a few major shifts in direction have taken place in the church"s entire history.

Dolgin (1974) also emphasizes the Importance of continuous revelation in the Mormon church. Using Bellah's evolutionary model she 1dentifled the church as a "modern" church, with members who are "modern symbollzers". Modern symbollzers in Bellah's terms are persons permitted (by the religious organization) to work out personal solutions, within a favorable environment, but free from the lmpositions of a set of authoritarian solutions or answers.

The data in this study did not support Dolgin's findings. While she speaks of "Mormons" (generalized term) as modern 
symbollzers who are different, and think differently from one another, this study presents evidence of another nature. Only $11 \%$ of the statements made by 94 persons in 70 to 100 hours of taped interviews, exhlbited thought patterns which were idiosyncratic or nontraditional. A few persons demonstrated an abllity to engage in independent reasoning about moral principles. This independence is described by Kohlberg (1963:14) as the highest level of moral development, "a morality of lindividual principles of consclence." The oppositional or independent statements all referred to a speciflc area and showed remarkable similarity in terms of rationalizing explanation.

Kohlbergs"s (1963:14) s1xth level and stage of moral development describes decisions which are the result of autonomous reasoning. According to kohlberg, this sixth and last stage, described as the highest stage of moral reasoning, is attained only by a few people. Most people do not progress beyond the fifth stage which is characterlzed by a "morallty of contract and of democratically accepted law".

What is even more surprising in $11 \mathrm{ght}$ of Dolgin"s Interpretations is that rationalizations offered by the subjects to explain their opposition to the church's position were theological in their nature. The individuals who could not accept or approve the church's position, defended their Individual princlples of consclence on the basts of the "Indissolubility of family bonds", and the religlous and eternal nature of the family. Their position $1 \mathrm{~s}$ not in agreement wh church dogma but reflects a cognitive shift which reduced the cognitive dissonance occuring in response to the autonomous reasoning process. It appears that they simple 
chose an alternative route on a familiar cognitive map for "Individual" expression. This decislve move suggests tactics to resolve the dissonance are not avallable in the formal church organization. Leone (1979) sees this as another evidence of the church"s direction away from the visionary inception of the church, toward a more conservative, authoritarian politio-religious position. The position is relinforced vila the collectlve education methods which are promulgated by the church. Programed instructions on all aspects of Mormonlsm are circulated from Salt Lake City of Mormons all around the world.

Mormons frequently point to the church"s insistence that each one of them develop their individual talents and emphasize their personal and unique 1dentification. Mormon children are taught from early chlldhood that each is unique and that it is fitting that they develop their abilities. But the manner of intervention by parents and educators to achleve this end is programmaticaaly embedded in religlous doctrine and dogma. There emerged from the data a category, descriptive of the "Ideal Proflle of the Salnt". Al1 instruction whether it is familial or a function of group soclallzation is directed toward the development of the ideal and desired personality, which it is hoped will result in behavior befltting the ideal, and expressing the collective personality.

Dolgin's utilization of Bellah's model to analyze the situations among Mormons in Arizona may be Justified by the nature of her data, but the Mormons in southern Utah do not appear to be "modern symbolizers". The evidence on hand lends itself more readily to interpretation on the basis of 
classical functionalism, a model which though unoriginal, recognizes the hierarchical and patriarchal structure of the church, and accords a moral value to its authoritarian approaches.

The basic premise of Weber's (1974) classical model is that the orgnization represents, and elfclts acceptance of those values central to a bellef system the internalization of whtch are necessary to the maintenance of the total unlt.

While some modern Saints do interpret for themselves within certain limits, no exceptional deviations from the centrally constructed ldeas and 1deals are tolerated. In order to malntaln oneself as a functioning member of the subculture it is essential to conform.

Major changes in the belief structure have been introduced only at moments in the history of the church when total equilibrium was threatened. In recent history, the pronouncement which outlawed polygamy; and the contemporary pronouncement extending the priesthood to blacks restored stability to the church as a whole by removing a source of embarassment from the members. In both of these examples a great many individuals inside the church had made their discomfort public, and in each case major criticlsm from American soctety at large impinged on the system demanding realigment in order to restore equilibrium.

Dolgin (1979) declares that the nembers of the church are held together by a few "key prescriptions" and she ldentifles "tithing" and the proscription of "alcohol and stimulating beverages" in these terms. Tithing is of vast importance to the malntenance of the religlous establishment but even tithing is dispensed with for those Mormons in financlal 
distress. But, the key prescriptions which support tithing and wthout which the establishment could not be maintalned are those central beliefs about family and marrlage. If the church is to persist, no radical reformation of these structures is possible. Because the earthly prescriptions and the Celestial promises are intimately intertwined. There is strong evidence of this reality in the works of Kimball (1969). The prophet thunders, that the ways of the world are not the ways of the Church of the Saints, and that Celestial Marriage and the famfly remain at the center of the belief system - nor can any threat to their continuance be countenanced within the walls. Wallace (1966) illustrates this point of view: "To the extent that religion supports the Individuals identification with the group, ...tt must define (however loosely and broadly) the boundarles of loyalty, assert that outsiders are outsiders, and Insist upon the distinctive virtues of one's own kind" (p. 26). Thus, nonconformists, or the unmarried within the church are relatively less esteemed (Arrington and Bitton, 1979) and individuals who deliberately choose nontraditional forms of sexual expression are rejected by disfellowshipping and eventual excommunication.

There is ample evidence in the data of this study, supported by the 11terature, to support the thesis that the religion of the Church of Jesus Christ of Latter Day Salnts is proscriptive in character, and that individualism is tolerated only within prescribed boundarles.

Accepting the evidence produced in the study and relating It to the theoretical positions generally presented by the scholars in the area of culture and cognition, the Investigator is contrained to propose that the effect of 
slowed psychosexual achievement in Mormon chlldren is substantially explained by the nature of the curtailing soclallzation process in Mormon education.

\subsection{Triangulation}

In order to establish construct validity, the findings of the qualitative analysis were considered together with those quantitative results from the prevlous study. The case for triangulation as a method to demonstrate construct validity arises from the position that no single approach ever resolves the question of rival related or causal factore (Webb, 1966; Kerlinger, 1973).

"The most fertlle search for validity comes from a combined serles of different measures, each with its 1 diosyncratic weaknesses, each pointed to a single hypothesis. When a hypothesis can survive the confrontation of a series of complimentary methods of testing, it contains a degree of validity unattalnable by one tested within the more constricted framework of a single method" (Webb, 1966:173-174).

When the investigator has a concern with discovery and verification, particularly in fleld research situations, or, when 1 is is hoped that the data w11 produce baseline data for new study directions, multiple methods, and the increased validity which they lend the findings, compensates for the additional input on the part of the investigator.

In Sohier (1981) it was reported:

- that a comparatively high number of children were below age/stage in psychosexual maturity;

- that the higher the parents scored on rigldity the greater 
the chance that child was below age/stage in psychosexual maturity.

In itself this finding is a first step to triangulation. The score for psychosexual maturity came from a test done by the chlld; the score for rigidity resulted from administering a form to the parent. In the last paragraph it was agreed, that the proscriptive nature of the Mormon subculture can explain such phenomena as the positive correlation between adult rigidity and slow maturation in chlidhood. The data of this research can put this hypothesis to a further test. It is not unreasonable to state that parents expressing lideosyncratic statements on elements of Mormon beliefs with regard to sexuality and gender identity in a qualitative interview, should be the same as the parents with low rigidity scores and whose children are within age/stage of psychosexual maturity.

This hypothesis can be tested by the bivariate and multivariate analysis of three variables, each from a different source.

- Age/stage

21 Children are within age/stage of psychosexual maturity; 26 are below.

- Rigldity

The parents are divided on thelr mean score on rigidity In 18 parental dyads with a low score and 29 with a high score.

- Ideosyncratic statements

In 16 parental dyads ideosyncratic statements were expressed with regard to sexuality and gender 1 dentity; in 31 dyads this was not the case.

As a first step in the analysis a chi-square test was done on 
the three bivariate tables that can be produced working with the varlables. The test results are the following:

- age/stage with rigldity $x^{2}=3.28 \mathrm{p}<0.05$ one sided

- age/stage with statements $x^{2}=8.83 p<0.001$ one sided

- rigidity with statements $x^{2}=6.04 p<0.01$ one sided The next step was to combine the three variables in one multivariate table.

Table 2. 47 parantal dyad according to age/ stage of the child rigldity test score ard the exprestom of 1 dilosycratic statements. Mormom commity 1977.

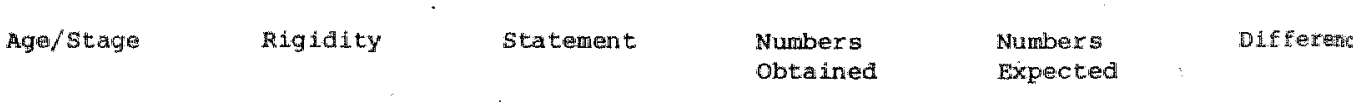

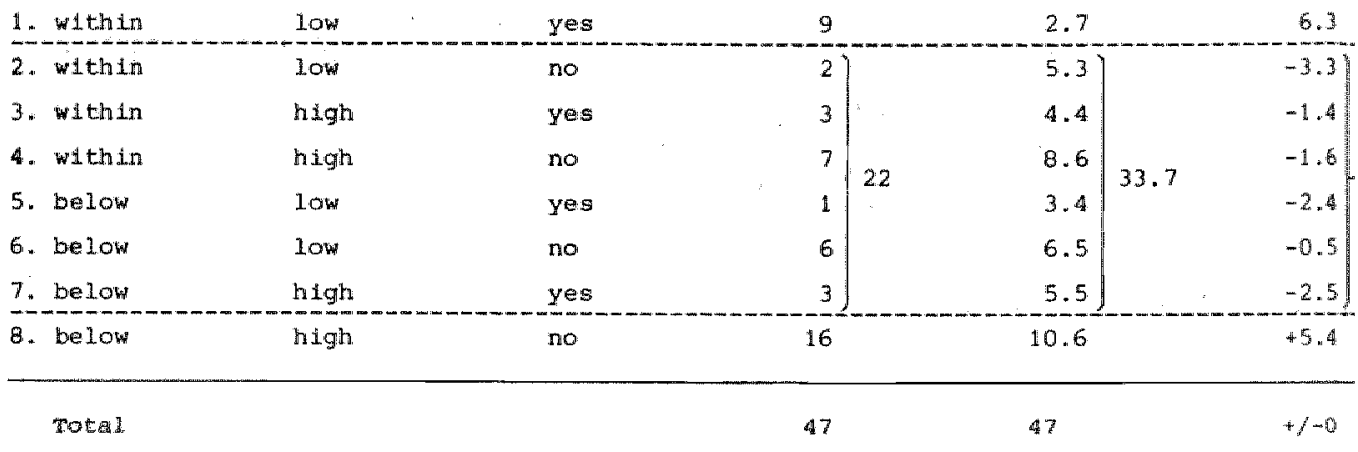

$x^{*}(1+2)$ w $(2-6)-1.35 \quad p<0.0001$ ane seded

The results presented in table 2 corroborate the general hypothesis: there are far more parental dyads of the extreme types (within age/stage, low rigldity and expressing statements vs below age/stage, high rigidity and not expressing statements) than can be expected by chance. 25 Parental dyads belong to elther of this types; 13.3 is the simple probability estimate for their number. 
When the results of the multiple methods are combined, there is strong evidence to support the theory that excessive adherence to prescriptions and proscriptions which are expressed in rigid childrearing approaches a negative influence on the developing cognitions of children. When the nature of the rigldity encompasses the cognitions describing gender identity and gender role the resulting effect is expressed in developmental delays of psychosexual maturtty.

Because the empirical evidence (nomonological) is firmly grounded in a nomonological net which described and demonstrates inter-relationships between constructs, and the details of the attendent properties, construct validity can be claimed.

Cronbach and Meeh1 (1955:290) state: "An enrichment of the net such as adding a construct or a relation to a theory is justified if it generates nomologicals which are confirmed by observation, or if it reduces the number of nomologicals required to predict the same observations." As to the development of theory, they require the following: "The proposed interpretation must generate specific testable hypothese which are means of confirming or disconflrming the claim." It can reasonably be argued on the basis of the evidence presented in this study that similar phenomenological networks will produce the attendant effects and that, conversely, emplrical evidence of like effects will be found rooted in corresponding constructs. It is therefore logical to present a theoretical position stating that, in groups where the boundarles of reality are set by proscriptive dogma, cognitive development in the children will exhibit significant deviation from the norms applicable to mainstream or less 
rigld socla1 groups.

Trlangulation methodology offers a greater measure of security by lincreasing validity in field research an advantage which Geertz (1977:482) described, "Confinement to experience near concepts leaves the researcher awash in immedlactes as well as entangled in vernacular. Confinement to experience distant ones leaves him/her stranded in abstractions and smothered in jargon." Triangulation or multi-methods allow the convergence of the findings and little doubt about their validity to explain the phenomena of Interest.

\subsection{Results of the analysis}

In contrast to psychoanalytic and behavioral theories of learning cognitive developmental theory makes the following assumptions:

1. Basic development involves bastc transformations of cognitive structure which cannot be defined or explained by the parameters of associationistic learning (contigulty, repetition, relnforcement, etc.), and which must be explained by parameters of organizational wholes or systems of internal relations.

2. Development of cognitive structure is the result of processes of interaction between the structure of the personality and the structure of the environment, rather than being the direct result of maturation or the direct result of learning (in the sense of a direct shaping of the subjec's responses to accord with environmental structures).

3. Cognftive structures are structures (schemata) of action. 
While influence of cognitive activities move from the sensorimotor to the symbollc to verbal-propositional modes, the organization of these modes is always an organization of actions upon objects.

4. The direction of development of cognitive structure is toward greater equilibrium in this subject-enviroment interaction, 1.e., of greater balance or reciprocity between the action of the subject upon the (perceived) object (or situation) and the action of the (perceived) object upon the subject. This balance in interaction, rather than a static correspondence of a concept to an object, represents "truth", "log $1 c^{\prime \prime, ~ " k n o w l e d g e ", ~ o r ~}$ "adaptation" in their general forms. This balance is reflected in the underlying stability (conservation) of a cognitive act under apparent transformation, with development representing a widened system of transformations maintaining such conservation. (Kohlberg, 1963, P. 348)

The assumptions enumerated by Kohlberg hold for the development of ways of thinking about physical and social objects, and he goes on to define social development saying, "it is in essence the restructing of 1 ) the concept of self: 2) in its relationship to concepts of other people, 3) conceived of being in a common soctal world with social standards." All the processes involved in physical cognitions are common to social developnent, but social development has an added dimension, that of role-taking.

The position of the cognitive developmental school is that children learn in a dialectical process with the environment. Aspects of enviroment act on the schemata or 
knowledge structures of the child and at the moment which the enviroment stimulates, and the child is ready to recelve the stimulus, a restructuring of the schemata occurs and the new knowledge is assimllated, thus permitting the child to move on to a more advanced stage of cognition.

Because the process fust described is dialectical in nature there are no givens about when a child will achleve any specific developmental level, and in consequence reasonable varlation of achlevement levels are to be anticlpated in any population.

There 18 overwhelming evidence that the central constructs of Mormonism are concerned and preoccupled wh the subject of appropriate understanding of gender identity and expression of gender roles. With family as a central religlous concept and marriage as the major property of famlly, it is clear that the most valued elements of the soclety encompass and support the development of a personality which is compatible with the value structure.

"Cognitive orfentation has affective or existential consequence and, one"s sence of one's place in the world or one's values, has a profound effect on one's perception of the world as an object" (Dolgin, 1979, p. 17). The early cognitive developmental tasks related to formation of gender concepts requlres the abllity to separate oneself from the environment and percelve oneself as a separate subject. Kohlberg (1963) explains that affective development and functioning and cognitive development and functioning are not distant realms, because there exists in the Individual a fundamental unity of personality organization and development named the "ego" reflected in self-concept. Psychosexual development and also 
moral development are strands of development united by their common reference to the self in a particular soclal world.

The development of the perception of self and early integration of personality in the area of psychosexual development has been described as a process, which to depend on little more than a normal expectable environment in which the child can accomplish, in his or her own time, those cognitive tasks which enable him or her to achieve a constant or consistent image of the self in psychosexual terns. That w111 say the child reaches an understanding that he or she is male or female, that this fact is true historically (the child was in the past and wil be in the future what he or she is now) and that this state cannot be changed by changing situations (e.g. by changing clothes or hair do).

It was clase to the end of his life that Plaget acknowledged that the social norms and socialization modes expressed in culture have an effect on the emerging comprehension of self as a separate object and in this case as a sexual being. Kluckhohn and Strodbeck (1961), and Greenfleld and Brunner (1974) have reported that children soclallzed in a group which emphastzes the "group" rather than the "Individual", have little awareness of his/her existence as an Individual, or In Kohlberg's terms it takes a longer perlod of time to complete "fundamental unlty of personality Integration", a stage of cognitive development which must be achieved in order to facilitate a constant perception of a psychosexual self.

It has been demonstrated earlier in this work that the values of Momonism rest with the family and communtty, thus expressing a collective rather than an lindividualistic 
orlentation.

There has been a general assumption among soctal scientists that values influence developmental outcomes. Also for child rearing Zavolloni's statement is valid (1980, p. 75) that "values represent a meeting place between the Individual and soclety". Kluckhohn (1951, p. 395) defines value: "A value is a conception, explicit or implicit, distinctive of an individual or charateristic of a group, of the desirable which influences selection from avallable modes, means and ends of action."

In the subculture of Mormonism there is a great emphasis placed on conformity and parents by their own admission stress faithfulness to the church's instructions as a valued aspect of their dally life.

Mormon chlldren are socialized in an atmosphere in which messages implicit, and explicit, confirm parental acceptance of the churches prescriptions and proscriptions. LeVine (1971) suggests that "the individuals in a given population are not necessarily aware of the evolved adaptations between personality and the institution in which they participate" ( $p$. 512). Herskov1ts (1967), Berger and Luckmann (1967) and Fried1 (1976) have made simflar statements indicating that cultural modes become internalized and desptte their pervasive nature, "...rarely intrude into consclous thought" (Herkovits, 1967, p. 4). But, these ldeas would seem Inapplicable in the subculture of Mormonlsm for Momons consclously ldentify their plans for socializing their children in a way which is acceptable to the church, and which they can reasonably expect to produce destred outcomes, in terms of adult personality and role expression. 


\subsection{Meanings}

This study accepts the basic premise that human belngs act toward things on the basis of the meanings things have for them, and that meanings are social in nature. Also, meanings are modified through an interpretative process on a personal level. Accepting these basic premises assumes that the variety of options which the person percieves as avallable in terms of interpretation have arisen in his relation with the environment in which he or she develops. Therefore, it is reasonable to suggest that a subculture which stresses "family and community" as a medium or framework for personal development will convey meanings which imply group solutions in preference to individual ones, and may thereby inhibit personal development.

The fact the Mormon parents have transferred so much of the decision making about child education to the church as an educational unit, identifies the existance in their midst of a "collective consciousness". This collective consciousness has moved Mormon parents to relinquish many aspects of individual control over child education and therefore child development by capltulating to the terms of a grand design.

Observation of the subculture of Mormonism supports this thesis in the following ways. The grand design of the church "the maintenance of the family structure", has become an integral part of the cognitive maps which establish life directions for individuals in the church; large sections of the educational venture have been removed from direct parental control and have become inserted in a total educational system administered by the church; and parents are reinserted in this program as educators so that a circultous indoctrination of 
purpose and form are built $1 \mathrm{n}$. The inclusion of parents in the educational venture, and the apparent sharing of power and responsibility for the organization whtch are invested in male members via the lay priesthood together succeed in convincing the rank and file that they are involved in decisions which are important to them.

The history of Mormonism and the continuing growth of the church membership elaborate the viability of the Mormon way of 11fe for its members. The church does provide a supportive framework for famfly 11 fe which appears to meet the needs of large numbers of contemporary world citizens. The continued success of the Church of Jesus Christ of Latter Day Saints Indlcates a shared consclousness among Mormons of the support avallable to persons who wish to create families and who place value on famlly assoclations. Theil shared experience validates the meanlings which they find in family and marriage. And the group experience provides satisfaction for many SaInts.

Berger and Luckman (1967) theorize that shared experlence $1 s$ one of the most valuable bases of bonding between indlifuals. The shared experience when made available linguistically to others becomes accesstble to them and may be relevant to them. The Mormon church engages in constant dissemination of information about the subject of family - a information base which is understood by most people in most places because of the universality of the family. While the construction of the Mormon family may be strange in cross-cultural context the kinship connotations can be explicated in such a way that they express meaning in terms which are cuiture specific. 
The collective orientation in the Mormon subculture is expressed in social tems by preparing individuals for roles as husbands and wives, mothers and fathers. That the process succeeds and satisfies many people is obvious: their church persists and it grouws in number. That its nature is predominately collective and not individualistic may also cause 1ittle concern to the subculture as a whole. However it has far reaching implications for the individualist or the non-conformist. While the church reasonably can be sald to offer a viable and even satisfylng sphere of development and expression for those who enjoy family life, it is not supportive of any who choose to express their personallties in idiosyncratic terms or non-traditional roles.

In this period of history many people are choosing a single life style (Mead \& Metraux, 1974). Growing economic Instability - which increases the need for mobility has been cited as a variable which is related to this change, increased hedonism, desire for higher education and the financial implications thereof, are a few of the possible reasons why some people choose to stay single. In these clrcumstances it is unfortunate to observe that single people are relatively less esteemed in the Church of Jesus Christ of Latter Day Salnts.

While Momons are a clearly identifiable group of people in some particulars they remain part of the greater American soclety, and their membership (especially that segment outside of the inter-mountain West) $\mathbb{1 s}$ buffeted by the same winds of change as other mainstream Americans.

Mormons who publicly admit a preference for a single Iffe style are suspect in their own subculture. The single 
Mormon, especlally the intellectual, experiences intermal and external stresses which are directly related to his/her single status. Inslde the subculture he/she is unequal, and if the single state is a matter of cholce is threatened with aternal discrimination. Only married men and their wives will be able to attain the Celestial Kingdom. So far the discussion has consldered "Id losyncratic" expressions of the self in the midst of the church, which produce stress and may result in loss of self-esteem.

But the single and otherwise conforming member is in 11ttle jeopardy when considered in juxtaposition to the idividual who is unmarried but wishes to express himself/herself sexually, or worse, in a homosexual relationship. These last are in true danger. They will be disfellowshipped, ostracized, and eventually excomunicated (K1mbal1, 1969). The church is kind and forglving to those who attempt to change their behavior and promise to abstain from sexual expression, but the sanctions executed against non-conformists are demoralizing. The person facing excommuntcation, has in all probabllity grown up in a loving conforming Mormon home and has internalized many of the bellefs and values of the subculture in interaction with his or her family. Excomuntcation separates the unrepantant person from his or her family for time and eternity. Sulcide is not uncommon among Mormon young people whose store of meanings fall to afford solutions which resolve these problems. There are no psychological supports within the official structure to assist the unrepentant, and access to family is denied, or make extremely difficult due to feelings of fallure which involve the love of family. It is clear that 
psychological equilibrium can be malntalned instde the subculture of Mormonism only when one lives a life of conformity.

The exaltation of the male in the Mormon subculture also inhibits the expression of personal characteristics by women. Women are not encouraged by the church to express themselves In any way which can detract in terms of time or princlple from the prototype held before Mormon women. If the Mormon woman should espouse the cause of equality for women as it is expressed in the matnstream culture, she must elther refrain from going public or suffer rejection.

The leadership of the church has in recent years espoused the causes of right wing politiclans and have assisted in every way with the organization of an opposition platform against the cause of equal rights for women (Leone, 1979). Their position is based on the conviction that the Mormon woman is equal in "Mormon terms" - since without her no Mormon man can achieve the Celestlal prize after which he strives. It is difficult, indeed impossible, for most women outside the subculture of Mormonism (and 1ndeed for many 1nside) to accept thls postion as one of equality - since Mormon women can under no circumstances get into the Celestlal KIngdom wh thout a man's assistance.

Recently the church made an example of one woman (Sonla Johnson, Dec. 1979), who maintained a supportive position regarding equal rights for women. She was excommunicated for her stance. Rationallzations referring to abortion issues, dissemination of birth control information and sex education In schools as part of the E.R.A. platform, inacceptable to the church were put forward to justify the position of the church 
but in the last analysls the question was one of patrlarchal authorlty. Women in the mainstream who support the equal rights amendment do not necessarily embrace any of the particular positions on abortion, ete. put forth by the platform in general.

\subsection{Conclusion}

Family and 1 ts property marrlage are major constructs which describe the cognitlve fleld in which gender develops and is expressed in the subculture of Mormonism.

The socialization of roles is carried out in such a way that collective values are stressed, and Indlvidualistic values minimized. The members of the church have relinquished much of the responsibility for role transference to an organized educationa1 arm in the church structure. The symbollc expression of meanings by the actions in the enviroment reflect the values central to the church and subculture and by their greater emphasis on group rather than Ind $1 v \mathbb{1 d u a l}$ values. The study offers evidence that the cultural mode inhibits the developlng cognitions which are a necessary part of psychosexual identity in childhood.

\subsubsection{Imp11cations of the study}

The results which emerge from this investigation confirm Plaget's position that culture and language intervene in the dialectical learning process between child and environment producing varlations in the chronological age at which children achleve certain cognitions. The study also provides evidence that rlgld socialization which dictates the boundarles within which thought must reside (by prescribing 
and proscribing) produces inhibiting effects on the developing cognitions of the children.

The focus of this investigation was psychosexual development in early childhood but it is reasonable to propose that other cognitions may be affected when rigidity encompasses material related to them.

The study findings imply that open famlly systems whlch are capable of incorporating information outside of the boundaries prescribed by their bellef system and individuals capable of using this information to formulate autonomous judgements of moral principle, provide a stimulating climate for the cognitive growth of their children.

The fact that a proportionately small number of the 94 adults were capable of such autonomous decision making sustains Kohlberg (1969) proposition that few people achieve the sixth level of moral development which he describes as the highest stage of moral reasoning.

\subsubsection{Limitations of the study}

A major limitation of the early study described in chapter 1 was the absence of a control group. The first study was planned as an experimental field study. A control group of 50 families in the mainstrean was planned. For reasons beyond the researcher's control, the study could not be completed as planned.

\subsubsection{Future Study Directions}

The evidence that rigld socialization patterns can effect the declages in cognitive developmental sequences (Sohier, 1981) and the present study which confirms the nature of the 
context in which socialization occurs in the Mormon subculture, lend credence to the proposition that social forms which by their regid interpretation and presentation of symbolic cues decrease the options or variety of stimuli avallable to the developing child, may inhibit his/her ability to complete the task.

The propositions which arise out of the study can be read $11 \mathrm{y}$ transformed into hypotheses for testing.

The condition of the study intimate that there may be a correlation between breadth of education and ability to achieve the sixth level of moral development described by (Kohlberg: 1966). The demographic data suggests that the parents capable of autonomous decisions of moral principle recelved their higher education in non-Mormon establishments. These factors could be examined in the future.

Having established the relationship between soclalization made and slowed psychosexual development the next step in pursulng the etfology of homosexuality would suggest a study which investigates the possible relations between delayed psychosexual development, and subsequent choice of erotic partners. 


\section{SUMMARY}

The field study of Mormon families was carried out to clarlfy the nature of the process whereby children come to an understanding of their sexual selves, and to 1dentify the socialization variables effecting the outcomes. The simple random sample consisted of 94 parents, and 47 children of both sexes. The child subjects ranged in age from 42-90 months. In the first phase of the study the findings lent support to the cognitive developmental position that the child"s understanding of his/her sexual identity and its appropriate expression in behavior occurs as a function of cognitive structural change and in sequential stages (Kohlberg, 1966). A majority of the children in the study evidenced slowed levels of psychosexual development for chronological age when measured against the norms developed by slaby and Frey (1976). A significant negative correlation was seen to exist between the child outcomes and parental scores on a rigldity of belief scale. An $F$ test for independent groups resulted in $F=2.09$ $(d f=25,20) p<0.05$. In het second phase of the study, 94 tape scripts obtained from the parents were analyzed using the inductive method of Glaser and Strauss (1967). The purpose of the study was to examine the phenomena surrounding the construct of gender identity and gender role in the Mormon subculture in order to properly ascribe the nature of the phenomena and increase the validity of the findings in Phase I. The theoretical construct which emerged described gender identity as a concept firmly embedded in the proscriptive and prescriptive teachings of the Church of Jesus Christ of the Latter Day Saints. Church dogma and the collective educational 
methods of the church comblne to support rigid approaches to chlld socialization in a majority of the families in the study.

A third phase of the study combined the results of the multiple methads of measurement. The purpose of this undertaking was to establish construct validity via a triangulation approach. The combined results offer strong evidence to support the theory that excessive adherence to external proscriptions and prescriptions of bellef on the part of parents and caretakers, expressed in rigld child soclalization modes, exerts a negative influence on the developing cognitions of children. When the rigidity encompasses the area of sexuality, limiting the boundaries of understanding of the concept, the effects are expressed in delays $\mathbb{1}$ achlevement of psychosexual maturity. 


\section{SAMENVATTING}

Teneinde het proces te bestuderen wardoor kinderen hun psychosexuele identiteit verwerven werd een veldonderzoek in een Mormoonse gemeenschap ultgevoerd. Daarbij richte het onderzoek zich vooral op aspecten van de soclalisatie die invloed hebben op de snelheld van psychosexuele ontwikkeling. Het eligenlijke onderzoek betrof 47 ouderparen, die tenminste drie kinderen hadden, en warvan het te onderzoeken kind tussen 42 en 90 maanden oud was in 1977.

In de eerste fase van het onderzoek werd vastgesteld, dat het inzicht van het kind In zijn elgen ontwikkeling een functie is van structurele, cognitieve veranderingen in opeenvolgende biologische leeftijdfasen (Kohlberg, 1966). Opvallend was echter dat de meerderheid van de kinderen in deze studie in psychosexuele rijpheld achterbleven bij een gemiddelde bevolking (Slaby en Frey, 1976). Een correlatie werd aangetoond tussen de rijpheid van het kind en de rigiditeitsscores van de ouders. Op het eerste gezicht leidt dat tot een paradox. Ouders die overeenkomstig hun godsdienstige leer en opvattingen het sterkst kinderen opvoeden in het besef van een pscyhosexuele 1dentitelt als jongens en melsjes, hebben kinderen die juist minder goed in staat zijn op een onafhankelijke test zich als "echte" jongetjes en meisjes te beschrijuen.

In de tweede fase van het onderzoek werden de 94 interviews met de ouders geanalyseerd met de inductieve methode van de "grounded theory" van Glaser en Strauss (1967). Het doel van dit onderdeel van de studie was die cultuurtrekken te beschrijven warin de ldee van geslachtelijke identitelt in de 
Mormoonse subculturr verankerd 11gt, om een beter begrip te krijgen van de resultaten ult de eerste fase. De theoretische begrippen ("contructs") die werden ontwikkeld, toonden aan dat gealachtelijke identitelt geen individueel gegeven is, maar onlosmakel1jk verbonden is met de proscriptleve leerstel1ingen van de kerk van de Latter Day Saints. Het gezinsleven krijgt vorm vanult strikte voorschriften van de godsdienst. Kerkelijke dogma's en collectieve opvoedingswijzen leiden tot rigide benaderingen van de socialisatie van het kind in de meerderheld van de bestudeerde gezilnnen.

Een derde fase van het onderzoek benutte de techniek van de trliangulatie teneinde de mate van construct-validiteit vast te stellen. De gegevens over deze rijpheid van het kind, de riglditeitsscores van de ouders en het in het kwalitatieve onderzoek wel of niet ulten van idiosyncratische ultspraken over psychosexualitelt hangen sterk samen. Deze uitkomst ondersteunt de theorle dat wanneer ouders een sterke neiging vertonen ulterlijke voorschriften op het gebied van het geloof en zijn matschappelijke implicaties te onderschrijven, zij klezen voor rigide methoden van opvoeding. Dientengevolge blijven hun kinderen achter in cognitieve ontwikkeling. Uit het onderzoek blifkt dat wanneer deze riglditeit ook de sexualiteit betreft, het kind in psychosexuele rijpheid achterblifft. Vermoedelijk heeft dit ook gevolgen voor zijn sexuele ontwikkeling en zijn sexuele voorkeuren op volwassen leeftijd. 


\section{B IBLIOGRAPHY}

Arrington, L.J., \& Bitton, D. The Mormon experience: A history of the Latter Day Salnts. New York: Alfred A. Knopf, 1979.

Bandura, A., \& Huston, A.C. Identification as a process of incidental learning. Journal of Abnormal and Social Psychology, 1961, 63, 311-318.

Bandura, A. \& Walters, R. Soclal learning and personallty development. New York: Holt, Rinehart and Winston, 1963.

Bandura, A., \& Jupers, C. Transmissions of patterning of self-reinforcement through modeliing. Journal of Abnormal and Soctal Psychology, $1964,6 \overline{9(1)}, 1-9$.

Bandura, A. Psychological modelling. Chlicago: Aldine-Allerton, 1971 .

Be1lah, R.N. In Lessa, W.A., \& Vogt, E.Z. (Eds.). Reader In comparative religion: An anthropological approach. New York: Harper and Row, 1972, p. 36-82.

Benoliel, J.Q. Social characteristiscs of death as a recorded hospital event. In Batey, M.V. (Ed.). Communicating Nurse Research, Vol. 8, Boulder, $\mathrm{CO}$ : Western Interstate Commission for Higher Education, 1977.

Berger, P.L., \& Luckmann, T. The soclal construction of reality: A treatise in the soclology of knowledge. New York: Anchor Books: Doubleday and Company, 1967.

Berry, J. Human ecology and cognitive style. New York: Wiley and Halsted. 1976.

B1umer, H. Symbolic interactionism: Perspective and method. Englewood C11ffs, NJ: Prentice-Hall Inc, 1969.

Boas, F. The mind of primltive man. 1911, Reprint, New York: The Free Press, 1965. 
Book of Mormon (The). Translated by Joseph Smith Jr., Salt Lake Clty, Utah: The Church of Jesus Christ of Latter Day Salnts, Publishers, 1974.

Bozett, F.W. Gay fathers: The convergence of a dichotonized Identity through integrative sanctioning. Unpublished Dissertation, San Francisco: University of Calffornia, 1979.

Brim, 0.G. Jr. Personallty development as role learning. In Oscoe, I., \& Stevenson, H. (Eds.). Personality development in children. Austin: University of Texas Press, 1960.

Brislin, R.W. In Brislin, R.W., Trlandis, H.C. Handbook of Crosscultural psychology: Social psychology, Vol. V, Boston, MA: A1lyn and Bacon, 1980, p. 1-23.

Brislin, R., Lonner, W., \& Thorndike, R. Crosscultural research methods. New York: Wiley, 1973.

Brodle, F.M. No man knows my history: The 1ife of Joseph Smlth. New York: Alfred M. Knopf, 1974.

Bruner, J.S., 01ver, R.R., and Greenfield, P.M. Studies in Cognitive Growth. New York: J. Wlley \& Sons, Inc. 1966.

Campbel1, B. Human Evolution. Chicago: Aldine, 1966.

Campbe11, D. Differences in perception as distinguished from fallures of communication. In: Crosscultural Understanding. (ed.) F.S.H. Northrup \& H.H. Livingston. New York: Harper \& Row, 1964.

Campbe11, D.T., Stanley, J.C. Experimental and quas 1-experimental designs for research. Chicago: Rand McNaliy, 1965.

Cole, M. Scribner, S. Culture and thought. New York: John W1ley and Sons, Inc., 1974.

Cronbach, La Jo and Meeh1, P.E. Construct Validty in Psychological Tests. Psychological Bulletin, 1955:52 pp. $281-302$. 
Dasen, P.R. The influence of ecology, culture, and European contact on cognitive development in Australlan aborigines. In J.W. Berry \& P.R. Dasen (eds..); Culture and cognition: readings in crosscultural psychology. London: Methuen, 1973.

Dasen, P.R. In Dasen, P.R. (Ed.). Plagetlan psychology: Crosscultural contributions. New York: Garnder Press, In.c, 1977.

Dasen, P.R., \& Heron, A. Crosscultural tests of Plaget's theory, In Trandis, H.L., \& Heron A. (Eds.). Handbook of crosscultural psychology: Developmental psychology, Vol. IV, Boston, MA: Allyn and Bacon, Inc., 1981.

De Vries, R. Constancy of generic ldentity in the years three to six. Monographs of the Soclety for Research in Chlld Development. $1969,34,3$.

De Vries, R. Relationship among Plagetian, I.Q., and achievement assessments. Child Development, 1974, 45, $746-756$.

Dolgin, J.L. Latter Day sense and substance. In Zaretsky, I. I. \& Leone, M. P. (eds.). Rellglous movements in contemporary America, Princeton University Press, p. 519-547.

Dolgin, J.L. Kemnitzer, D.S., \& Schnieder, D.M. (Eds.). Symbolic anthropology: A reader in the study of symbols and meanings. New York: Columbia University Press, 1977.

Dogner, L.F., Beaton, J.A., \& Glass, H.P. Life-Death decision making in health care. Unpublished Study, Winnipeg, Manitoba, Canada: University of Manttoba, College of Nursing, 1981 .

Dubois, c. Some motions on intercultural understanding. In G. Splndler (ed.). Education and anthropology.

Stanford: Stanford University Press, 1955, pp * 89-126.

Eggan, D. Hopi dreams in cultural perspective. In LeVine, $R$. (Ed.). Culture and personality, Chlcago: Aldine Publishing Co., 1974. Reprinted with permission from the regents of the University of California. 
Elkin, E, The child and soclety: The process of soctallzation. New York. Random House, 1972. Reprinted, or Iglna1 1960 .

Emmer1ch, W., Goldman, K., Kirsh, B., \& Sharabary, R. Evidence for a transitional phase in the development of gender constancy. Child Development, 1977, 48, 930-936.

Er1kson, E. Ident1ty: Youth and crisis. New York: Norton, 1968.

Gal1ther, G. \& Bas11ck, L. Utahs Drug Laws: Structural. Foundations and Triggering Events. Social Problems, Feb. 1979; Vol. 26:3, pp. 285-295.

Garbarino, J. \& Bronfenbrenner, U. The Soclallzation of Moral Judgement and Behavior in Crosscultural Perspective. In T. Lickona (ed.). Maral1ty: A Handbook of Moral Development and Behavior. New York: Holt, Rinehart \& Winston, 1976.

Geertz, C. Religion as a cultural system. In Lessa, W.A., \& Vogt, E.Z. (Eds.). Reader in comparative religion: An anthropological approach. New York: Harper \& Row, 1972, p. 167-179.

Geertz, C. The interpretation of cultures. New York: Basic Books, 1973.

Geertz, H. The vocabulary of enotion: A study of Javanese soclalization process. In LeVine, R. (Ed.). Culture and Personal1ty. New York: Aldine Publishing Co., 1974.

G1111n, J. Maglcal thought. Psychlatry, 1948, 11, 387-400.

Glaser, B.G., strauss, A.L. The discovery of grounded theory: Strategles for qualitative research. Chilcago: Aldine Publishing Co., 1967.

Glittenberg, JoAnn, E. Fertility patterns and childrearing of the Ladinos and Indians of Guatemala. In: M.M. Leininger (Ed.). Transcultural Nursing Care of Infants and Children. Salt Lake City: University of Utah College of Nursing, 1977, pp. 156-160. 
Goffman, E. The presentation of self in everyday 11fe. New York: Doubleday, 1959.

Greenberg, G. Equity, Equality, and the Protestant Ethic. Journa1 of Experimenta1 Psychology. 1978:14 pp. 214-226.

Greenfleld, P.M. \& Bruner, J. Culture and cognitive growth. In Goslin, D. (Ed.). Handbook of soclallzation theory and research. Chicago: Rand McNally \& Co., 1971, p. $633-661$.

Hallowell, A. Irving Culture and Experience. Philadelphia: University of Pennsylvania Press, 1955.

Herskovits, M. Cultural dynamics. New York: Alfred A. Knopf, 1967.

Kardiner, A. The Individual and Hls Soclety. New York: Columbia University Press, 1939.

Kenda11, K. Maternal and Child Care in an Irantan V11lage. In: M.M. Leinfinger (Ed.). Transcultural Nursing Care of Infants and Children. Salt Lake City, Utah: University of Utah College of Nursing, $1977 \mathrm{pp}$. 19-33.

Kerlinger, F.M. Foundation of behavioral research. New York: Holt, Rinehart \& Winston, Inc., 1973.

Kimball, S. Culture and the educative process: An anthropollcical perspective. New York: Teachers of College Press, 1974.

Kimball, S.W. The miracle of forglveness. Salt Lake City, Utah: Bookcraft Inc., 1969. (Publishers Press, Inc., 1981,32 nd ed.)

Klaus, P. and Kennel, J.H. Parent-Infant bonding. St. Louls, Ma.: Mosby Co., 1982; (2nd ed.)

Kluckhohn, C. Values and value orlentations in the theory of action. In Parsons, T., \& Shils, E.A. (Eds.). Toward a general theory of action. Cambridge: Harvard University Press, 1951, p. 388-433. 
Kluckhohn, F.R., Strodtbeck, F.L. Varlations in value orlentations. Evanston, IL: Row, Peterson, 1961.

Kohlberg, L. The development of chlldren's orientations towards a mora1 order: 1. Sequence in development of moral thought. Vita Humana, 1963,6 , 11-33.

Kohlberg, L. Stage and sequence: The cognitive developmental approach to soclallzation. In Goslin, D. (Ed.). Handbook of soclallzation theory and research. Chicago: Rand McNa11y and Co., 1971.

Kohlberg, L. A cognitive developmental analysis of sex role concepts. In A. Skolnick, \& J.H. Skolnick (Eds.). Family in transition. Boston: Little, Brown and Company, 1971.

Kohlberg, L. A cognitive developmental analysis of chlldren"s sex role concepts and attitudes. In E.E. Maccoby (Ed.). The development of sex differences. Stanford, California: Stanford University Press, 1966, 82-110.

Larandau-Ben-David, M. Culture, schooling and cognitive developinent. In Dasen, P.R. (Ed.). Plagetian psychology. New York: Gardner Press, 1977, p. 123-169.

Leininger, M.M. Nursing and anthropology: Two worlds to blend. New York: John W1ley \& Sons, Inc., 1970.

Lelndinger, M.M. The Gadsup of New Gulnea and Early Childrearing Behaviors with Nursing Care Implications. In Transcultural Nursing Care of Infants \& Children. Salt Lake City: University of Utah College of Nursing. 1977 pp. 201-219.

Lefninger, M.M. Transcultural nursing: Concepts, theories and pract1ces. New York: John Wiley \& Sons, 1978.

Lenski, G. E. and Lenski, J. Human Socletles. New York: McGraw H111 Book Co., 1974.

Lenski, G. The Religious Factor. New York: Doubleday, 1961. 
Leone, M.P. The economic basis for the evolution of the Mormon religion. In Zaratsky, I.I., \& Lenoe, M. (Eds.). Religious movements in Contemporary America. Princeton: Princeton University Press, 1974.

Leone, M.P. Roots of modern Mormonism. Cambridge, MA: Harvard University Press, 1979.

LeVine, R. Dreams and deeds: Achlevement motivation in Nigeria. Chicago: University of Chicago Press, 1966.

LeVine, R.A. Cross-cultural study of child psychology. In P.H. Mussen (Ed.). Carmichael's Manual of Child Psychology (Vol. II). New York: J. Wiley and Son, 1970.

LeVine, R.A. Culture personality and socialization: An evolutionary view. In Goslin, D. (Ed.). Handbook of soclalization theory and research. Chicago, Rand McNally \& Co., 1971, p. 503-543.

LeVine, R.A. Culture, behavior and personality. Chicago: Aldine Publishing Co., 1973.

LeVine, R. Patterns of Personality in Africa. Ethos, 1973:1 pp. $132-152$.

Levi-Strauss, C. The Family. In L. Shapiro (Ed.). Man, Culture and Society. New York: Oxford Untversity Press, 1960.

Levy-Bruh1, L. How natives think. 1910. (translated) Boston: Beacon Press, 1966.

Lloyd, B.B. Studies of conservation wth Yoruka children of differing age and experience. Child Development, 1971, $42,412-428$.

Lloyd, B.B. Perception and Cognition from a Crosscultural Perspective. Hammondsworth: Penguin, 1972.

Lloyd, B.B. and Archer, J. Exploring Sex Differences. New York: Academic Press, 1976. 
Mann, L. Cross-cultural studles of small groups. In Tralnd1s, H.C., \& Brislin, R.W. (Eds.). Handbook of cross-cultural psychology: Social Psychology, Vol. V. Boston, MA: A11yn and Bacon, Inc., 1980, p. 155-211.

McConkie, B.R. Mormon doctrine. Salt Lake City, Utah: Bookcraft, Inc., 1966.

Mead, G.H. Mind, self and soclety. Chicago: University of Chicago, Press. 1934.

Mead, M. Culture and Committment. Garden City, New York: Doubleday \& Co. Inc., 1970.

Mead, Me, \& Metraux, R. A way of seeing. New York: W1111am Morrow \& Co. Inc., 1974 .

Middelton, G. From Child to Adult. Garden City, New York: The merican Natural History Press, 1970.

Miller, J.K., Roedell, W.C., Slaby, R.g., \& Robinson, H.B. Sex role development in intellectually advanced children. Unpublished manuscript. Developmental Research Group, N1-20. University of Washington, Seat11e, WA, 1979.

Mirels, H.L. \& Garrett, J.B. The Protestant Ethic as a Personallty Varlant. Journal of Consulting Psychology. $1971: 36 \mathrm{pp} \cdot 40-44$.

Mische1, W. Sex-typling and soclalization. In P.H. Mussen (Ed.). Carmichael's Manual of Ch11d Psychology. New York: J. Wiley and Son, 1970.

Money, J., \& Ehrhardt, A.A. Man and woman, boy and gIr1. Baltimore: John Hopkins Unlversity Press, 1972.

Money, J. Sexual dimorphlsm and homosexual gender Identity. N. I.M.N. Task Force on Homosexuality: Final Report and Background Papers. Washington, D.H.E.W. Pub. No. (Adm.) $76-357,1976$.

O'Dea, T. The Mormons. Chicago: University of Chicago Press, 1957. 
Parsons, T., \& Bales, R.F. Family, socialization and interaction process. Glencoe, IL: Free Press, 1955.

Pelto, P.J., \& Greta1, H. Antrhopologlcal research: The structure of inquiry. Cambridge, MA: Cambridge University Press, 1979.

Pelto, P.J. Enthnography: The fieldwork enterprise. In Honigmann, J.J. (Ed.) . Handbook of social and cultural anthropology. Chicago: Rand McNa11y, 1973.

Philipsen, H., Reek van J. \& Drop, M.J. Stabiliteit en regionale verschillen in sterftecijfers in de periode 1955-1978. Maastricht: Rijksuniversiteit Limbrug, 1983.

Pilaget, J. The psychology of intelligence. London: Routledge, Kegan Paul, 1947.

Piaget, J. The origins of intelligence in children. New York: International Universities Press, 1952.

Piaget, J., \& Inhelder, F. Le development des quantities cher 1'enfant. Neuchatel: De Tachaux \& Niestle, 1941.

Price-Williams, D.R., \& LeVine, R.A. Left-right orientation among Hausa children: A methodological note. Journal of Cross-cultral Psychology, 1974, 5, 356-363.

Robbins, R.H. Identity, culture and behavior. In Honigmann, J.J. (Ed.). Handbook of soclal and cultural anthropology. Chicago: Rand McNa11y \& Co., 1973.

Schatzmann, L., \& Strauss, A.L. Field research: Strategies for a natural sociology. NJ: Prent1ce-Ha11, Inc., 1973.

Sheany, G. Passages. New York: E.P. Dutton \& Co., Inc., 1976.

Skinner, B.F. Science and human behavior. New York: MacMillan, 1953.

Skinner, B.F. The operational analysis of psychological terms. In H. Feig1, \&. Brodbeck (Eds.). Readings in the philosophy of sclence. New York:

Appleton-Century-Crofts, 1953. 
Slaby, R., Frey, K. Development of gender constancy and selective atcention to same- sex models. Child Development, $1975,46,849-856$.

Sohter, R. The 1nfluence of Mormon soclalization on gender development in childhood. Unpubilshed Thesis, Chicago: University of Chlcago, 1981 .

Sorenson, J.L. In: Arrington, L.J.., \& Bitton, D. (Eds.). The Mormon experience. New York: Alfred A. Knopf, 1979, p. $309-310$.

Spiro, M. Children of the Kibbutz. Cambridge MA.: Harvard University Press, 1958.

Spradley, J.P. The ethnographlc interview. New York: Holt, Rinehart Winston, 1979.

The Church News. Week ending March 27, 1982. Sa1t Lake C1ty, Utah: Deseret News, Publlshers.

T1111ch, P. Political Expectation. Hannah Tillich (Ed.). New York: Harper Row Pubs., Inc., 1971.

Turner, V.W. Color classiflcation in Neemdu Ritual. In: Anthropological approaches to the study of religion. M. Banton (Ed.). London: Tavistock, 1966.

Turner, W. The Mormon establishment. Boston, MA: Houghton Miffiln Company, 1966.

Wallace, A. Reilgion: An anthropological view. New York: Rand om Howse, 1966.

Wallace, A. Culture and personallty. New York: Rand on House, 1970.

Weber, M. The theory of soctal and exonomic organization. New York: McMillan Pubilshing Co., 1947.

Weber, M. The Protestant Ethic an the Spirit of Capitalism. New York: Scribners, 1958.

Webster. Webster's new collegiate dictionary. Springfleld, MA: G. C. Merrlam Co., 1975. 
Werner, H. Comparative psychology of mental development. New York: Science Editions, 1961.

Zavalloni, M. Values. In: Triandis, H.C., \& Brislin, R.W. (Eds.). Handbook of cross-cultural psychology. Vol. V, Boston, MA: Allyn and Bacon, Inc., 1980, p. 73-121. 



\section{APPENDIX A}

TABLE A.1. STAGE RESPONSE PATTERNS ACCOROING TO SLABY AND FREY

\begin{tabular}{|c|c|c|c|}
\hline Type & $\begin{array}{l}\text { Gender } \\
\text { Identity }\end{array}$ & $\begin{array}{c}\text { Gender } \\
\text { Stability }\end{array}$ & $\begin{array}{c}\text { Gender } \\
\text { Constancy }\end{array}$ \\
\hline \multicolumn{4}{|l|}{ Stage } \\
\hline 1 & + & - & - \\
\hline 2 & + & - & - \\
\hline 3 & + & + & - \\
\hline 4 & + & + & + \\
\hline
\end{tabular}




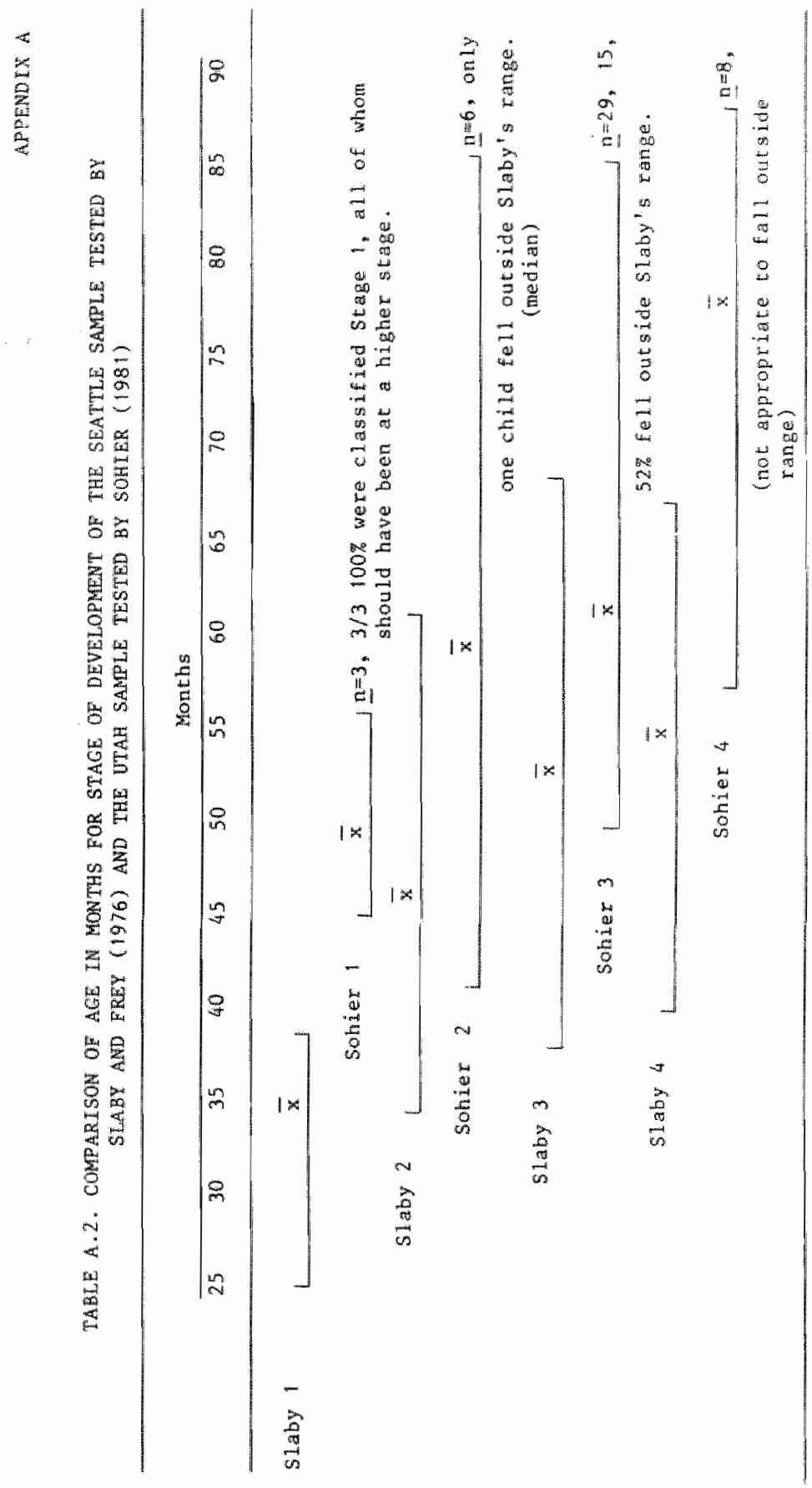


APPENDIX B

PARENTS QUESTIONNAIRE

1. Check one: Mother Father

2. Name:

3. Your Telephone Number: Area Code

4. Your Address:

\section{C1ty}

5. Your Age:

6. Your Occupation:

7. Your Religion:

8. Family Income (check one):

$\$ 5,000$ - $\$ 10,000$ yearly

$\$ 10,000$ - $\$ 15,000$ yearly

$\$ 15,000$ and above

Questions 9-12 to be completed by one parent only.

9. List children in your family by age and sex.

Name

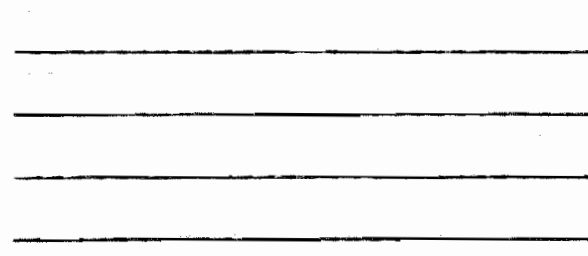

Age

$\begin{array}{lllll}- & M & F & \text { Yes } & \text { No } \\ - & M & F & \text { Yes } & \text { No } \\ - & M & F & \text { Yes } & \text { No } \\ - & M & F & \text { Yes } & \text { No }\end{array}$

10. Name of child taking part in study: 


$$
-166-
$$

11. Birth date of child taking part in study:

12. Would you be wlling for your child to become a part of a long term study? Yes No 


\section{APPENDIX B (continued) ${ }^{*}$}

Please circle one number for each 1 tem. Do not look back at your answers as you go on. Thank you.

\begin{tabular}{ccl} 
Strongly Agree Disagree & Strongly \\
Agree & Disagree & $\begin{array}{l}\text { Opinion } \\
\text { Don't } \\
\text { Know }\end{array}$ \\
\hline
\end{tabular}

1. Religious

bellefs are of

vital importance

in family life.

1

2

3

4

5

*2. Churches should provide guidance in childrearing. 1

2

3

4

5

3. It is more important for parents to spend time with children of the same sex than children of the opposite sex.

4. The church to which I belong emphasizes training children to be masculine and feminine.

*5. The way children

are reared affects their adult sexuality.

*) Items with arterisks were used as probing questions in the inverview. 


\section{APPENDIX B (continued)}

Please circle one number for each 1 tem. Do not look back at your answers as you go on. Thank you.

Strongly Agree Disagree Strongly No

Agree
Disagree Oplinion Don" $t$

Know

6. He terosexuals and homosexuals are equally valuable people.

2

3

4 5

7. Parents should discourage children from playing games or doing things which are opposite sex things (e.g. , boys playing with do11s).

3

4 5

8. It is alle right for small ch11dren to bathe together.

3

4 5

9. Chlldren ralsed in a religious atmosphere with good parental examples w11 want to get married and have chlldren.

1

2

3

4 5

*10. Children Iearn adult tasks by imitating adults and relating to adults. 


\section{APPENDIX B (cont fnued)}

Please circle one number for each item. Do not look back at your answers as you go on. Thank you.

\begin{tabular}{ccc}
$\begin{array}{c}\text { Strongly Agree Disagree } \\
\text { Agree }\end{array}$ & $\begin{array}{l}\text { Strongly } \\
\text { Disagree }\end{array}$ & $\begin{array}{l}\text { Nopinion } \\
\text { Don't } \\
\text { Know }\end{array}$ \\
\hline
\end{tabular}

11. A satisfying

family life is

possible wi thout

religious

affiliation.

1

2

3

4

5

12. Parents should

show disapproval

when children do

opposite sex

things.

1

2

3

4

5

13. Re1iglous beliefs

and values are

the basis of child

rearing practices

in al1 famflies. 1

2

3

4

5

14. Parents should bathe with their children of the same sex.

4 5

15. Boys need more education than girls.

4 5

16. Religion is the most 1mportant thing in $11 f e$ and marriage is second. 


\section{APPENDIX B (continued)}

Please clrele one number for each 1 tem. Do not look back at your answers as you go on. Thank you.

\begin{tabular}{ccl}
$\begin{array}{c}\text { Strongly Agree Disagree } \\
\text { Agree }\end{array}$ & $\begin{array}{l}\text { Strongly No } \\
\text { Disagree }\end{array}$ & $\begin{array}{l}\text { Oplnion } \\
\text { Don't } \\
\text { Know }\end{array}$ \\
\hline
\end{tabular}

17. It is less disturbing to hear that a woman is homosexual than
a man.
1
2
3
4
5

*18. The religion to which I belong is a fanily centered religton.

19. Parents should provide equal educational opportunities for male and female children.

20. Parents' level of education determines how they rear thelr children.

21. Adult example is the most significant part of character formation in children.

22. It is more 1mportant for men to marry than women. 


\section{APPENDIX B (continued)}

Please circle one number for each item. Do not look back at your answers as you go on. Thank you.

Strongly Agree Disagree Strongly No

$$
\text { Agree }
$$

Disagree Opinton Don"t Know

*23. Children reared in a house where religlous beliefs and values are stressed are not likely to become homosexual adults. 1

2

3

4 5

24. Religious belief have little to do with the way people rear children.

2

3

4 5

25. One of the functions of my church

is education not just religious education but other kinds also.

26. The way parents rear their children is responsible for children becoming homosexual adults.

27. Married and unmarried people are equally valuable persons. 1 


\section{APPENDIX B (continued)}

Please clrcle one number for each 1 tem. Do not look back at your answers as you go on. Thank you.

\begin{tabular}{ccc} 
Strongly Agree Disagree & $\begin{array}{l}\text { Strongly } \\
\text { Disree }\end{array}$ & No \\
& & $\begin{array}{l}\text { Opinton } \\
\text { Don't } \\
\text { Know }\end{array}$ \\
\hline
\end{tabular}

28. Parents should punish children who persist in doing opposite sex things itke dressing in opposite sex clothing, boys using make up or girls being real tomboys. 12 3 4 5

29. Parental in-

fluence will not

affect the sexua1 behaviors of their children in adul thood.

2

3

4 5

30. The way ch11dren are reared in fluences how masculine or feminie they become.

31. Parents cannot be blamed for the way their children turn out as adults. 


\section{APPENDIX B (continued)}

Please circle one number for each item. Do not look back at your answers as you go on. Thank you.

Strongly Agree Disagree Strongly No

$$
\text { Agree }
$$

Disagree Opinion Don't Know

32. Homosexua1 adults have not been reared in a religious atmosphere.

1 2

3

4

5

33. People who do not have children lead an impoverished 1ife.

1

2

3

4

5

34. Homosexuals are not responsible for their sexual preferences, they have been badly reared. 
APPENDIX C

PERMISSION FORM

Date

We hereby consent to become subjects in the study conducted by Raphella Sohter and also give permission for our child to participate.

The study had been explained to us and we understand that the Information given will be treated in confidence, and that any of us can withdraw from the study at any time.

Mother

Father 


\section{APPENDIX D: Expert raters}

\section{THOMAS P. NIELSON}

Born: February 9, 1937, Huntington, Utah. Marrled: 1961, Bonnie Pace, two children. B.A.: 1962, Brigham Young University, Asian Studies/History.

Ph.D.: 1969, University of Washington, Chinese Literature.

Professional Appointments:

Assoclate Professor of Chinese, Arizona State University, 1969-74. Church Educational System Director, 1977 to present.

Ecclesiastical Appointments:

Taiwan-Taipei Mission President, 1974-77. Ann Arbor Michigan Stake Presidency, 1977 to present.

Publications :

The $\mathrm{T}^{\prime}$ ang Poet-Monk Chiao-jan. Arizona State University, Center for Asian Studies, Occastonal. Paper no. 3, June 1972. 65 pp.

"Two Track Service Course and Advanced Modules: Individualized Learning and Peer Teaching Method s" Journal of the Chinese Language Teachers Association. October 1974, pp. 126-133.

Wei Ying-Wu Shih-Chu Y1n-te. San Francisco: Chinese Materials Center, Inc., 1976. Ixx111, 220 pp.

Editor, Yeh-Ho-Hsuan Tsa-Yin (Randon Lyrics from Wild Crane Studio), by Vincent Y. C. Shih. Arlizona State University, Center for Asian Studies, 1976. 
Activities:

Assistant Editor and Associate Acting Director, Astan Forum: A Quarterly Journal of Aslan Affairs, 1969-73; Offlcer at Large, Pacific Area Intercolleglate Council on Aslan Studies, 1971-74; Coordinator of Asian Languages, Arizona State University, 1969-74; Acting Director, Center for Aslan Studies, Arizona State University, 1973; Llason Officer, Danforth Fellowships, 1972-74; Director, Department of Forelgh Language and Literature Symposium, Arizona State University, 1972-73; Papers read regularly at the Western Conference of the Assoclation of Asian studies and the Conference of Astan studies on the Pacific Coast 1967-74; NDEA Fellow, 1963-65; Fulbright-related NDFL Fellow, 1966; Assisted in translating the Book of Mormon and Doctrine and Covenants into Chinese; research and publishing focus: "The Taoist Aesthetic in $T^{\prime}$ ang Dynasty Poetry".

Lecture Toplcs:

"Worshiping the Dead: From Confucius with Love" "Do I Want to Organlze My Family Like a Chinese Clan?"

"Eight Mouths in a Chinese Boat" 


\author{
APPENDIX D (Continued) \\ Professional Vita Sheet \\ December, 1979
}

Laws, Duane Marvin

Adress: 360 Edison Avenue

Ypsilanti, Michigan 48197

Birth Date: 27 Apri1, 1931

Marital Status: Wife - JoAnn

Children: Stephen, December 8, 1957; Mark, November 26, 1959; Suzanne, September 8, 1961; Philip, March 26, 1963; Cathy Jo, October 1, 1964; James, May 27, 1967; Areta Lynne, November 1, 1971

Education: High School: Provo High School, 1946-1949

College: B.A. Degree, June 1958, Brigham Young University

Major: Human Development and Family Relationships

Minor: Psychology

M.A. Degree, August 1959, Brigham Young University

Major: Human Development and Family Relationships

Minor: Personnel and Guldance

Ed.D. Degree, August 1964, Columbia Unfversity, Teachers College, New York City

Major Field: Family Life Education and Marrlage Counseling

Present Position: Professor of Family \& Child Development, Home Economics, Eastern Michigan University, Ypsilanti, Michigan 
Professional Experlence:

Research Assistant, Brigham Young University, 1957-1958

Part-time Instructor, Brigham Young University, 1958-1959

Instructor, Brigham Young Unlversity, 1959-1960

Fellowship, Columbia Teachers College, 1960-61, 1961-62

Teaching Assistant, Columbia Teachers College, Sumer 1961,1962

Instructor, New York Unlversity, Spring Term, 1961-1962

Assistant Professor, Brigham Young Unlversity, 1963-1965

Assoclate Professor, Brigham Young University, 1966-1971

Department Chairman, Child Development and Family

Relationships Brigham Young

University, $1965-1969$

Sabbatical Leave at Eastern Michigan University, $1969-1970$

Coordinator, Fam11y Consultation Center, Brigham Young University, 1970-1971

Professor, Eastern Michigan University, 1971 to present

Organizations served as an officer, member of consultant:

Vice-President, Utah Division, American Association of Marriage Counselors, 1967-1969; Associate member and member, American Association of Marriage and Fam1ly Counselors, 1965-1970.

Family Perspective journal, Book Review Editor, $1970-1972$.

Chalrman, Research Section, Michigan Home Economics Association, 1973 to 1975.

Publications :

M.A. Thesis Brigham Young University, 1959. "Comparison of the Religlous Orthodoxy and Marltal Adjustment of Individuals with Temple and Non-Temple Marriages." unpublished.

Ed.D. Project. Columbla University, Teachers College, 1964, "Concepts of Marriage Education at the College Leve1" , unpub11shed. 
"Does Your Family Speak In (Parentheses)?", an article in The Latter Day Salnt Family, A Book of Selected Readings, Blalne R. Porter, Editor, Deseret Book Company, 1966.

"Social Class Differences in Marital Sex Behavior", Eamily Perspective Vol. II, 1966.

"When Couples Seek Counseling and What a Marriage Counselor May Be Able To Do For Them" Family Perspective, Vol. 4, Spring, 1969. "Bibllotherapy for Couples who Experlence

Difficulties in Marital Sex Adjustments" , with

Raymond Preston, Vol. 4, Family Perspective. Spring, 1969.

"Parent Leadership at Home", Utah PTA Bulletin, March 1971

"Potentials for Postive Parenting - Some Projections", MHEA Newsletter, 1974. "Where is the "home" in Home Economics?" Michigan $\mathrm{ECO}$, Vol. 1, No. 1, Winter, 1978. 
APPENDIX E

THE ARTICLES OF FAITH OF

THE CHURCH OF JESUS CHRIST OF LATTER DAY SAINTS

1. We belleve in God, the Eternal Father, and in His Son, Jesus Christ, and in the Holy Ghost.

2. We belleve that men will be punished for their own sins, and not for Adam's transgression.

3. We belleve that through the Atonement of Christ, all mankind may be saved, by obedience to the laws and ordinances of the Gospel.

4. We belleve that the flrst priclples and ordinances of the Gospel are: first, Faith in the Lord Jesus Chrlst; second, Repentance; third, Baptism by immersion for the remission of sins; fourth, Laying on of hands for the gift of the Holy Ghost.

5. We belleve that a man must be called of God, by prophecy, and by the laylng on of hands, by those who are in authority to preach the Gospel and administer in the ordinances thereof.

6. We belleve in the same organization that existed in the Primitive Church, viz:, apostles, prophets, pastors, teachers, evangelists, etc.

7. We belleve in the glft of tongues, prophecy, revelation, vislons, healing, interpretation of tongues, etc.

8. We belleve the Blble to be the word of God as far as $1 t$ is translated correctly; we also belleve the Book of Mormon to be the word of God. 
9. We belleve all that God has revealed, all that He does now reveal, and we believe that He will yet reveal many great and important things pertaining to the Kingdon of God.

10. We believe in the literal gathering of Israel and in the restoration of the Ten Tribes; that Zion will be bullt upon this (the American) continent; that Christ will relgn personally upon the earth; and, that the earth will be renewed and recelve its paradislacal glory.

11. We claim the privilege of worshiping Almighty God according to the dictates of our own consclence, and allow al1 men the same privilege, let them worship how, where, or what they may.

12. We belleve in being subject to kings, presidents, rulers and magistrates, in obeying, honoring, and sustaining the 1.aw.

13. We belleve in being honest, true, chaste, benevolent, virtuous, and in doing good to all men; indeed, we may say that we follow the admonition of Paul - We belleve all things, we hope all things, we have endured many things, and hope to be able to endure all things. If there is anything virtuous, lovely, or of good report or praiseworthy, we seek after these things.

- Joseph Smith

Taken from: Petersen, M.E. A word of wisdom. Salt Lake City, Utah: Published by the Church of Jesus Christ of Latter Day Saints, p. 22-23. 


\section{CURRICULUM VITAE}

The author was born in 1935 in Edinburgh, Scotland.

In 1957, upon complet1on of basic nursing studies at Leith and the Western General Schools of Nursing, Edinburgh, she was licensed as a Registered General Nurse. Post-basic nursing education was set forth in Voorburg, Netherlands.

She was married to Armand Sohier; Antwerp, Belgium, in 1958.

From 1958-1969 she fulfilled various nursing functions in Belgium. Among these were a working relationship with the late Professor Rene Dellaert, Untversity of Louvain, Department of Psychiatry; and, various functions in nursing at the Commissie van Openbare Onderstand (Pub1ic Hea1th) between 1961-1969.

After the death of her husband in 1968, she emigrated to the United States. In 1970 she studied at Michigan state University. In 1974 she earned a Master of Science degree at Central Washington University, Ellensburg, Washington. The Master"s thesis, titled. "Interactions of Culture and Environment Which Effect the Health of the Kekchi", was completed following a six month period of fleld study in Central Ameríca.

From 1972-1974 she appeared continuously on the Dean's 1ist of exceptional students at Central Washington University. 
In 1974 she was appointed Instructor of Nursing at University of Utah's College of Nursing in Salt Lake City.

In 1975 she was appointed Assistant Professor of Public Health Nursing at University of Illinois at the Medical Center, Chicago, in a part-time capacity. From 1975-1979 she was a full-time student in the Doctor of Philosophy in Nursing program at the College of Nursing in the same institution, and during a two year period was awarded a nurse traineeship grant from the U.S. Department of Health, Education and Welfare.

In the periode 1977-1979 she received three research assistantships at the same university, two in the college of Nursing and one at the Center for Craniofactal Anomalies, Abraham Lincoln College of Medicine.

In 1979 she was appointed Assistant Professor of Nursing at Wayne State University, Detrolt, Michigan in the Department of Community Health Nursing.

In 1980 she inftiated the work contact with University of Limburg, Netherlands, in the capacity of consultant to the developing program in Soclal Health Care, Department of Nursing Sciences. She speaks Dutch and has to her credit several publications, video-presentations and translations.

In 1981 she wrote a thesis titled, "Mormon Soclalization and It's Influence on Gender Development in Childhood." She was awarded a Master of Sclence degree in Public Health Nursing. 
In October, 1982 she was appointed Assoclate Professor in the Graduate Program in Nursing at The University of Oklahoma Health Science Center, Oklahoma. 